Juliana Vieira

Efeitos de Baccharis coridifolia em camundongos portadores de linfoma

São Paulo

2010 


\section{JULIANA VIEIRA}

\section{TÍTULO}

Efeitos de Baccharis coridifolia em camundongos portadores de linfoma

Dissertação apresentada ao Programa de PósGraduação em Patologia Experimental e Comparada da Faculdade de Medicina Veterinária e Zootecnia da Universidade de São Paulo, para a obtenção do título de Mestre em Ciências

\section{Departamento:}

Patologia

\section{Área de Concentração: \\ Patologia Experimental e Comparada}

\section{Orientador:}

Profa. Dra. Silvana Lima Górniak

São Paulo 
Autorizo a reprodução parcial ou total desta obra, para fins acadêmicos, desde que citada a fonte.

DADOS INTERNACIONAIS DE CATALOGAÇÃO-NA-PUBLICAÇÃO

(Biblioteca Virginie Buff D’Ápice da Faculdade de Medicina Veterinária e Zootecnia da Universidade de São Paulo)

Vieira, Juliana

Efeitos de Baccharis coridifolia em camundongos portadores de linfoma / Juliana Vieira. -- 2010.

$106 \mathrm{f.}$ : il.

Dissertação (Mestrado) - Universidade de São Paulo. Faculdade de Medicina Veterinária e Zootecnia. Departamento de Patologia, São Paulo, 2010.

Programa de Pós-Graduação: Patologia Experimental e Comparada.

Área de concentração: Patologia Experimental e Comparada.

Orientador: Profa. Dra. Silvana Lima Górniak.

1. Baccharis coridifolia. 2. Tricotecenos macrocíclicos. 3. Linfoma A20. 4. Tratamento antitumoral. 5. Camundongos nude. I. Título. 


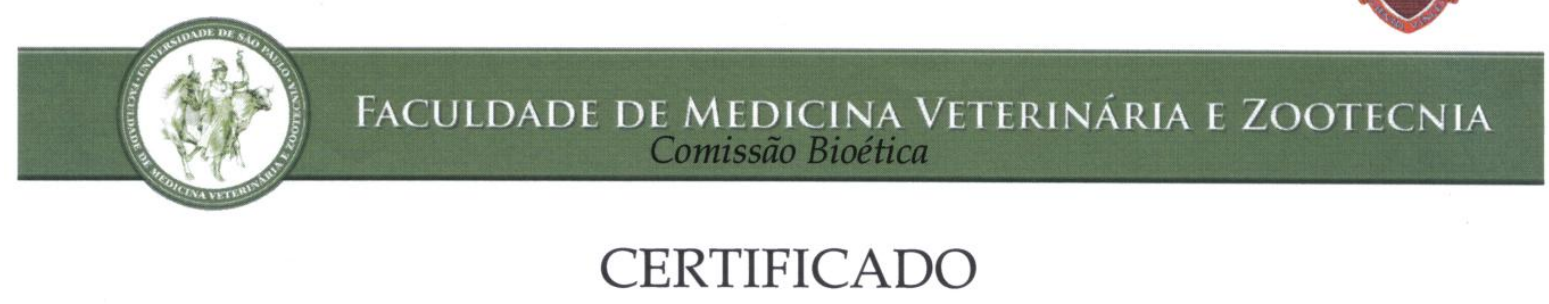

Certificamos que o Projeto intitulado "Avaliação dos efeitos de Baccharis coridifolia em camundongos portadores de Linfoma", protocolado sob o n⿳1300/2008, utilizando 120 (cento e vinte) camundongos, sob a responsabilidade da Profa. Dra. Silvana Lima Górniak, está de acordo com os princípios éticos de experimentação animal da Comissão de Bioética da Faculdade de Medicina Veterinária e Zootecnia da Universidade de São Paulo e foi aprovado na reunião do dia 20 de fevereiro de 2008.

We certify that the Research "Evaluation of Bacharis coridifolia effects in lymphoma-bearing mice", utilizing 120 (one hundred twenty) mice, protocol number 1300/2008, under the responsibility Profa. Dra. Silvana Lima Górniak, agree with Ethical Principles in Animal Research adopted by Bioethic Commission of the School of Veterinary Medicine and Animal Science of University of São Paulo and was approved in the meeting of day 02/20/08.

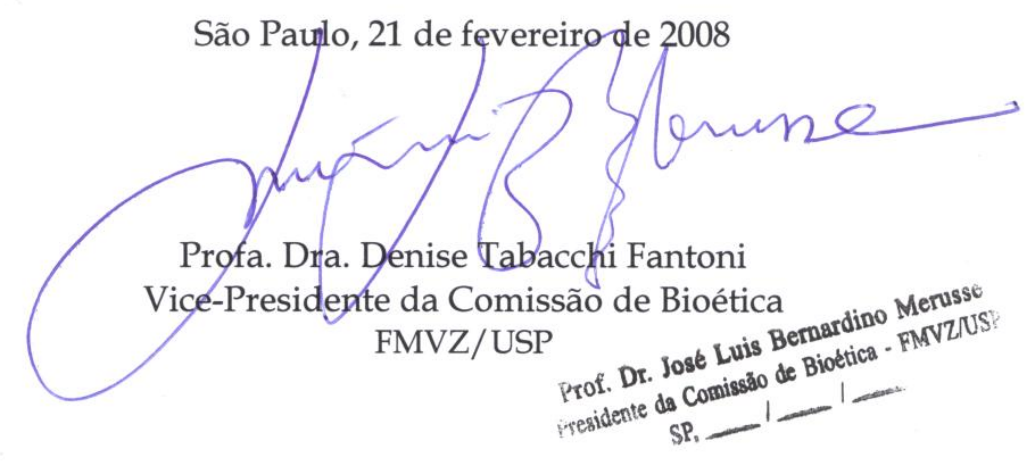




\section{FOLHA DE AVALIAÇÃO}

Nome: VIEIRA, Juliana

Título: Efeitos de Baccharis coridifolia em camundongos portadores de linfoma.

Dissertação apresentada ao Programa de PósGraduação em Patologia Experimental e Comparada da Faculdade de Medicina Veterinária e Zootecnia da Universidade de São Paulo, para a obtenção do título de Mestre em Ciências

Data:

Banca Examinadora

Prof. Dr.

Instituição:

Assinatura:

Julgamento:

Prof. Dr.

Instituição:

Assinatura:

Julgamento:

Prof. Dr.

Instituição:

Assinatura:

Julgamento: 
CAgradecimentos 


\section{AGRADECIMENTOS}

À minha orientadora Profa. Dra. Silvana Lima Górniak, ao transmitir seus conhecimentos e experiências profissionais com dedicação.

Aos meus amigos de pós-graduação Andréia Oliveira Latorre, Fernando Pípole, Luciana Cunha, Luciana Lippi, Beatriz Dorr Carniceiro, Camila Lima, Felipe Santos, e tantos outros que estiveram presentes e contribuíram para a conclusão deste trabalho.

Aos profissionais do Departamento de Patologia, em especial a querida Cláudia Madalena Cabrura Mori, sem a qual este trabalho não poderia ter sido concluído, aos amigos e funcionários do laboratório de histologia e de toxicologia, Claudio Arroyo e Luciano A. Bugalho.

Ao Clairton Marcolongo Pereira, pelo envio das amostras da planta.

À minha amiga Simone Gonçalves, pela paciência e compreensão.

À Faculdade de Medicina Veterinária e Zootecnia da Universidade de São Paulo pela oportunidade.

À FAPESP pelo apoio financeiro (Processo $n$ o. 2007/56665-0). 


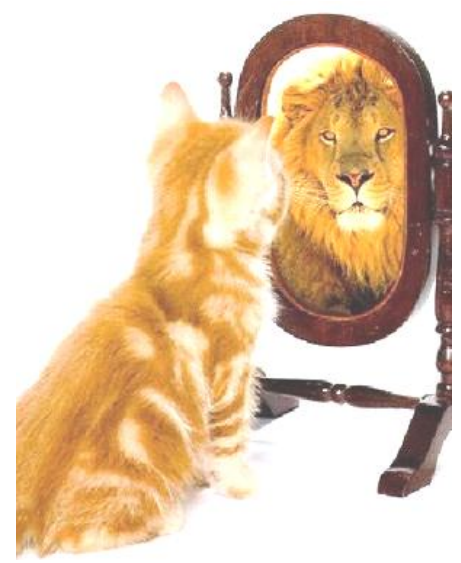

"QDe tudo, ficaram três coisas: a certeza de que estava sempre comecando, a certeza de que era preciso continuar e a centeza de que seria interrompido antes de terminar. Ffazer da interrupsão um caminho novo. Gazer da queda um passo de dança, do medo uma escada, do sono uma ponte, da procura, um encontro". 


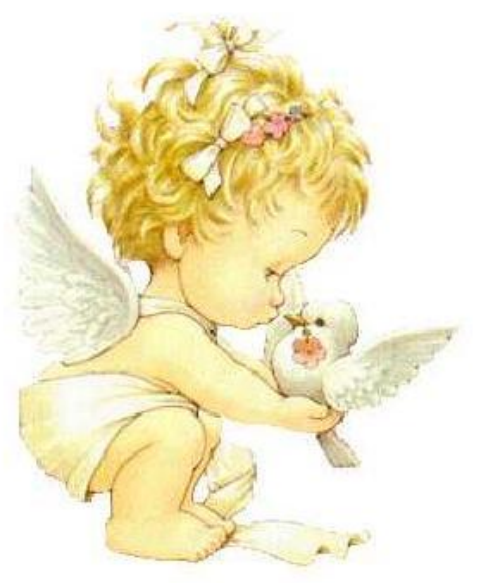

Llos meus pais

هnez e Antonio Đieira

"Xa tua força, busquei inspiraçẫo para lutar.

(D) sua luta, nasceu a chance de vencer.

Sa vitória, quero agora, muito mais que agradecer,

\& $m$ teus sorrisos, quero me inspirar para novas lutas

e vitórias que eternizarão a sua liçẫo de viver." 
Alos que Amo

"Algradecer é admitir que houve um momento em que se precisou de alguém,

安 reconhecer que o homem jamais poderá lograr para si o dom de ser auto-suficiente.

Singuém e nacta crescem sozinhos, sempre é preciso um olhar de apoio,

uma palavra de incentivo. Al todos vocês que compartilharam os meus ideais

e os alimentaram. Al vocés que, mesmo distantes, mantiveram-se ao meu lado,

Dedico esta vitória, com a mais profunda gratidũo e respeito." 


\section{RESUMO}

VIEIRA, J. Efeitos de Baccharis Coridifolia em camundongos portadores de linfoma. [Baccharis Coridifolia's effects on lymphoma affected mice]. 2010. $106 \mathrm{f}$ Dissertação (Mestrado em Ciências) - Faculdade de Medicina Veterinária e Zootecnia, Universidade de São Paulo, São Paulo, 2010.

A Baccharis coridifolia é uma planta tóxica da família Compositae, gênero Baccharis L., conhecida popularmente como "mio-mio", a qual é encontrada no sul do Brasil e também em algumas regiões do Estado de São Paulo. Em bovinos, a intoxicação provoca lesões necróticas no trato gastrintestinal e nos tecidos linfóides sólidos em geral, com exceção do timo. Já em camundongos, a $B$. coridifolia promove, além das lesões em órgãos linfóides, lesões necróticas também no timo. Os princípios ativos da B. coridifolia foram isolados e identificados como sendo os tricotecenos macrocíclicos: roridinas $A, D$ e $E$; verrucarinas $A$ e $J$ e miotoxina $A$. Em relação ao mecanismo de ação, trabalhos recentes in vitro demonstraram que as roridinas e as verrucarinas, promovem apoptose em tecido linfóide. Deste modo, considerando a toxicidade desta planta aos tecidos linfóides, o objetivo do presente estudo foi investigar se linfócitos tumorais (linfoma) seriam mais sensíveis aos efeitos tóxicos da $B$. coridifolia que linfócitos normais. Para tal, fez-se um experimento in vitro com culturas de linfócitos provenientes do baço e timo de camundongos hígidos, bem como células do linfoma murino A20 e carcinoma mamário de Ehrlich tratadas com o Resíduo Hexânico $(\mathrm{RH})$ obtido do extrato etanólico de B. coridifolia por 24 horas. A viabilidade celular foi verificada pela técnica $\mathrm{MTT}$, na qual se evidenciou diminuição da viabilidade das duas linhagens tumorais tratadas, linfoma A20 e carcinoma de Ehrlich, sem alteração na viabilidade dos linfócitos normais. Para melhor caracterizar este efeito tóxico do $\mathrm{RH}$ em linfócitos tumorais, camundongos nude (NMRI-nu/nu) foram inoculados com células A20, sendo posteriormente tratados por via oral, durante sete dias, com $\mathrm{RH}$, associado ou não a uma aplicação intraperitoneal do quimioterápico ciclofosfamida no primeiro dia 
de tratamento. Resultados mostraram que os animais tratados com $\mathrm{RH}$ foram menos afetados com a ocorrência de metástase do linfoma primário para outros órgãos e que as involuções tumorais foram mais expressivas no grupo submetido à associação deste tratamento com uma aplicação de ciclofosfamida. Estes resultados permitem sugerir que linfócitos tumorais são mais suscetíveis aos efeitos tóxicos da B. coridifolia.

Palavras-chave: Baccharis coridifolia. Tricotecenos Macrocíclicos. Linfoma A20. Tratamento antitumoral. Camundongos nude. 


\section{ABSTRACT}

VIEIRA, J. Baccharis Coridifolia's effects on lymphoma affected mice. [Efeitos de Baccharis Coridifolia em camundongos portadores de linfoma]. 2010. 106f Dissertação (Mestrado em Ciências) - Faculdade de Medicina Veterinária e Zootecnia, Universidade de São Paulo, São Paulo, 2010.

Baccharis coridifolia is a toxic plant from Compositae family, genus Baccharis L., known as "mio-mio". It is found in the south of Brazil, as well as in some regions of São Paulo state. In bovines, its intoxication leads to necrotic injuries to gastrointestinal tract and linfoid tissues. In mice, B. coridifolia leads, apart from linfoid solids in general to necrotic injuries in thymus. $B$. coridifolia's active principles were isolated and identified as being macrocyclic tricotecenes: roridines $A, D$ and $E$; verrucarines $A$ and $J$ and miotoxine $A$. Related to action pathway, recent research (in vitro) has shown that roridines and verrucarines, B. coridifolia's active principles, lead to apoptosis in linfoid tissues. Therefore, considering this plant's toxicity to linfoid tissues, this work aimed the study of whether tumoral lymphocytes (lymphoma) would be more sensitive to $B$. coridifolia's effects than regular lymphocytes. In this sense, an experiment was carried out (in vitro) using healthy mice's lymphocytes from spleens and thymus, as well as cells from murine A20 lymphoma and Ehrlich breast carcinoma treated with a residue $(\mathrm{RH}$, hexane obtained) from a $B$. coridifolia's ethanol effusion ( 24 hours). The cell viability was tested using MTT technique, where a decrease in viability was found for treated tumoral cells lineages, A 20 lymphoma and Ehrlich carcinoma, with no changes in normal lymphocytes viability. To find a better characterization to RH's toxic effect in tumoral lymphocytes, nude mice (NMRI-nu/nu) were inoculated with A 20 cells and then were orally treated, during 7 days, with $\mathrm{RH}$, and, in some cases, with intraperitonial injection of cyclophosphamide, during the first day of treatment. Results showed that $\mathrm{RH}$ treated animals were less affected to primary lymphoma metastasis in other organs and tumoral involutions were more prominent in the group treated with cyclophosphamide 
concomitantly. These results suggest that tumoral lymphocytes are more susceptible to B. coridifolia's toxic effects.

Key words: Baccharis coridifolia. Macrocyclic tricotocenes. A 20 lymphoma. Antitumor treatment. Nude mice. 


\section{LISTA DE ABREVIATURAS}

FMVZ - Faculdade de Medicina Veterinária e Zootecnia da Universidade de São Paulo $\mathrm{BC}$ - Baccharis coridifolia

EB1 - Extrato bruto da primeira amostra de Baccharis coridifolia (fevereiro 2008)

EB2 - Extrato bruto da segunda amostra de Baccharis coridifolia (setembro 2008)

EE1 - Extrato Etanólico da primeira amostra de Baccharis coridifolia (fevereiro 2008)

EE2 - Extrato Etanólico da segunda amostra de Baccharis coridifolia (setembro 2008)

$\mathrm{RH}$ - Resíduo hexânico

RHC - Resíduo hexânico associado à ciclofosfamida 


\section{SUMÁRIO}

Página

1 INTRODUÇÃO 20

1.1 SOBRE A Baccharis coridifolia E SEUS PRINCÍPIOS ATIVOS -20

1.2 SOBRE OS TRICOTECENOS MACROCÍCLICOS

1.3 PRINCÍPIOS ATIVOS DE PLANTAS E SEUS POTENCIAIS USOS

TERAPÊUTICOS

2 OBJETIVOS 29

2.1 OJETIVO GERAL DO PROJETO

2.2 OBJETIVOS ESPECÍFICOS

3 MATERIAIS E MÉTODOS 31

3.1 ANIMAIS 31

3.2 DROGAS E REAGENTES 31

3.3 MATÉRIA VEGETAL 32

3.4 PROCEDIMENTOS 33

3.4.1 Obtenção dos extratos de Baccharis coridifolia 33

3.4.2 Identificação dos tricotecenos macrocíclicos no extrato etanólico de

Baccharis coridifolia

3.4.3 Identificação dos tricotecenos macrocíclicos no resíduo hexânico de Baccharis coridifolia

3.4.4 Administração dos extratos aos animais 36

3.4.5 Ganho de peso dos animais 36

3.4.6 Manutenção do linfoma A20 in vitro 36

3.4.7 Manutenção do tumor de Ehrlich in vivo 37

3.4.8 Contagem global das células da medula óssea 37

3.4.9 Hemograma, bioquímica sérica e peso relativo do baço e timo 37

3.4.10 Avaliação histopatológica- 38 
3.4.11 Inoculação do linfoma A20 em camundongos nude

3.4.12 Padronização da cultura de células tumorais A20, esplenócitos

e timócitos in vitro

3.4.13 Cultivo celular de linfoma A20, tumor de Ehrlich, esplenócitos e timócitos, sob tratamento com EE2 e RH de Baccharis coridifolia

3.4.14 Cultivo celular de linfoma A20, tumor de Ehrlich, esplenócitos e timócitos, sob tratamento co $\mathrm{RH}$ de Baccharis coridifolia

3.5 ANÁLISE ESTATÍSTICA

4 DELINEAMENTO EXPERIMENTAL E RESULTADOS

4.1 EXPERIMENTO 01 - AVALIAÇÃO DA TOXICIDADE DOS EXTRATOS BRUTOS E ETANÓLICOS DE Baccharis coridifolia

4.1.1 Resultados Experimento 01

4.2 EXPERIMENTO 02 - AVALIAÇÃO DA TOXICIDADE DO RH DE Baccharis coridifolia EM CAMUNDONGOS NUDE

4.2.1 Resultados Experimento 02

4.3 EXPERIMENTO 03 - TRATAMENTO DE CAMUNDONGOS BALB/C E SWISS

COM SOLUÇÃO DE EB1 E EE1 DE Baccharis coridifolia-

4.3.1 Resultados Experimento 03

4.4 EXPERIMENTO 04 - DETERMINAÇÃO DOS VALORES DE REFERÊNCIA PARA PARÂMETROS HEMATOLÓGICOS, BIOQUÍMICOS E ISTOPATOLÓGICOS DE CAMUNDONGOS NUDE

4.4.1 Resultados Experimento 04

4.5 EXPERIMENTO 05 - EFEITO DO RH SOB CAMUNDONGOS NUDE PORTADORES DO LINFOMA A20

4.5.1 Resultados Experimento 05

4.6 EXPERIMENTO 06 - PADRONIZAÇÃO DA TÉCNICA DE MTT PARA AVALIAÇÃO DAS CÉLULAS TUMORAIS A20, ESPLENÓCITOS E TIMÓCITOS 72 
4.7 EXPERIMENTO 07 - TRATAMENTO DE CÉLULAS DE LINFOMA A20, ESPLENÓCITOS E TIMÓCITOS COM DIFERENTES DOSES DE EE2 E RH 74

4.7.1 Resultados Experimento 07 75

4.8 EXPERIMENTO 08 - TRATAMENTO DE CÉLULAS DE LINFOMA A20, TUMOR DE EHRLICH, ESPLENÓCITOS E TIMÓCITOS COM RH 1mg/ml 76

4.8.1 Resultados Experimento 08 77

4.9 EXPERIMENTO 09 - IDENTIFICAÇÃO DOS TRICOTECENOS MACROCÍCLICOS NO EXTRATO ETANÓLICO DE B. Coridifolia $-78$

4.9.1 Resultados Experimento 09 79

4.10 EXPERIMENTO 10 - IDENTIFICAÇÃO DOS TRICOTECENOS MACROCÍCLICOS NO RESÍDUO HEXÂNICO DE B. Coridifolia 83

4.10.1 Resultados Experimento 10 83

5 DISCUSSÃO 88

6 CONCLUSÕES 99 REFERÊNCIAS 
Introdução 


\section{INTRODUÇÃO}

\subsection{SOBRE A Baccharis coridifolia E SEUS PRINCÍPIOS ATIVOS}

A Baccharis coridifolia pertence à família Compositae, gênero Baccharis L., conhecida popularmente como "mio-mio". Esta planta "é um subarbusto dióico (as inflorescências da planta fêmea e macho aparecem em espécimes separadas), de 50 a $80 \mathrm{~cm}$ de altura, ramosa, com folhas lineares agudas de 15 a $25 \mathrm{~mm}$ de comprimento por 1,2 a $5 \mathrm{~mm}$ de largura. Possui capítulos numerosos dispostos em rácinos densos nas extremidades dos ramos. Os capítulos femininos têm de 8 a 10 flores brancas e filiformes. Os espécimes masculinos apresentam invólucro campanulado, as flores são de 10 a 18, com papilhos brancos e crespos" (OCHIONI, 1944). A B. coridifolia habita os campos nativos de áreas não úmidas. A ocorrência desta planta está relacionada com o clima subtropical úmido; assim no Brasil a $B$. coridifolia é mais comumente encontrada no Rio Grande do Sul, na fronteira com Uruguai e Argentina e, ainda, nos estados de Santa Catarina, Paraná e até no estado de São Paulo (TOKARNIA, 2000).

A B. coridifolia é uma das plantas tóxicas mais importantes do sul do Brasil (OCCHIONI, 1944). Para designar plantas de aspecto semelhante a esta, a população acrescenta adjetivos ou usa o diminutivo como "mio-mio grande" e "mio-miozinho"; no entanto, até o momento só se reconhece como planta tóxica duas espécies de Baccharis, a saber: $B$. coridifolia e B. megapotamica. Deve-se salientar, neste contexto que no Mato Grosso do Sul, o termo "mio-mio" é usado de forma indiscriminada para muitas plantas supostamente tóxicas, algumas com leve semelhança com a $B$. coridifolia; entretanto, esta espécie não ocorre neste estado (TOKARNIA, 2000).

As espécies sensíveis à intoxicação por esta planta, sob condições naturais, são, sobretudo a bovina e a ovina (BARROS, 1993), mas suínos e eqüinos também podem se intoxicar (COSTA, 1995). A intoxicação espontânea pela $B$. coridifolia é mais comum em animais originários de regiões onde não há a planta, recém-introduzidos nas 
pastagens de sua ocorrência. Animais oriundos de regiões onde a planta ocorre, geralmente não ingerem a planta, salvo nos casos de animais muito jovens, quando começam a pastar, após queimadas no pasto ou em superlotação do rebanho. Sob condições experimentais, há estudos em bovinos (TOKARNIA; DOBEREINER, 1976; VARASCHN; BARROS; JARVIS, 1998), ovinos (TOKARNIA; DOBEREINER, 1976), coelhos (DOBEREINER; REZENDE; TOKARNIA, 1976), eqüinos (COSTA, 1995) e camundongos (VARASCHIN, 2002).

Há grande variação na toxidez de $B$. coridifolia. De fato, muitos fatores podem influenciar o conteúdo de metabólitos secundários de uma planta. A época em que uma planta é coletada é um dos fatores de maior importância, visto que a quantidade, e até mesmo a natureza dos constituintes ativos, não é constante durante $\mathrm{O}$ ano todo. $\mathrm{A}$ idade e o desenvolvimento da planta, bem como dos diferentes órgãos vegetais, também são de considerável importância e podem influenciar não só a quantidade total de metabólitos produzidos, mas também as proporções relativas dos componentes de misturas. Sabe-se também que tecidos mais novos geralmente possuem maior taxa biosintética de metabólitos, tais como óleos essenciais, lactonas sesquiterpênicas, ácidos fenólicos, alcalóides, flavonóides e estilbenos (GOBBO-NETO; LOPES, 2007). De fato, nota-se frequentemente uma correlação inversa entre alta atividade metabólica e produção de aleloquímicos, isto é, um decréscimo na produção de metabólitos secundários em períodos de crescimento tecidual rápido.

Em relação à $B$. coridifolia, fatores como sazonalidade, temperatura, disposição hídrica, gênero e partes da planta, radiação ultravioleta e idade, influenciam na toxicidade. Assim, por exemplo, durante o verão do Rio Grande do Sul, no mês de março (planta em floração e frutificação) a $B$. coridifolia pode ser cerca de quatro a oito vezes mais tóxica do que em outubro-novembro (planta em brotação). A proporção planta seca para planta verde de $B$. coridifolia, em termos de peso, foi estabelecida como 1:4 na brotação e 1:3 na floração (TOKARNIA; DOBEREINER, 1976); porém, a planta perde aproximadamente a metade de sua toxidez no processo de dessecação. A planta feminina pode ser até 32 vezes mais tóxica do que a masculina. São tóxicas todas as partes da planta, na seguinte ordem decrescente: flores e sementes, folhas, talos e raiz. Em experimentos em coelhos com B. coridifolia em floração, as partes aéreas da planta juntas (flores, inflorescências e sementes) foram até 16 vezes mais 
tóxicas, quando comparadas somente com as folhas (TOKARNA; DOBEREINER; PEIXOTO, 2000).

As manifestações clínicas observadas em bovinos intoxicados com "mio-mio" em geral são semelhantes aquelas observadas nas outras espécies animais, tais como nos camundongos e se caracterizam por anorexia, timpanismo, instabilidade dos membros posteriores, tensão abdominal aumentada, sensibilidade abdominal. Os animais apresentam muflo seco, secreção ocular, atonia ruminal, leve sialorréia, polidipsia, taquipnéia e tremores musculares (TOKARNIA; DOBEREINER, 1976; VARASCHIN; BARROS; JARVIS, 1998). Em alguns casos, as fezes dos bovinos intoxicados mostram-se ressequidas (TOKARNIA; DOBEREINER, 1976) outras situações, ao contrário, verifica-se diarréia profusa, associada a estrias de sangue (VARASCHIN; BARROS; JARVIS, 1998). Nota-se em bovinos intoxicados com a planta verde recémcolhida, o início das manifestações em cerca de cinco a 29 horas, e o tempo decorrido entre o aparecimento do quadro clínico e a morte, de quatro a 34 horas. Com a planta dessecada, a oscilação em bovinos, nos casos fatais, oscila entre oito e 63 horas, e o prazo entre a administração da planta e a morte do animal entre 25 e 75 horas (VARASCHIN; BARROS; JARVIS, 1998). A evolução da intoxicação nos quadros que culminam com a morte do animal é sempre aguda. Em geral, a toxicidade em bovinos pode variar entre 0,25 a $2 \mathrm{~g} / \mathrm{kg}$ da planta fresca.

Os achados de necropsia em bovinos são de congestão e erosão da mucosa do trato gastrointestinal, com presença de edema e petéquias, sendo ainda possível verificar em alguns casos conteúdo hemorrágico em ceco e cólon (BARROS, 1993; VARASCHIN; BARROS; JARVIS, 1998). Órgãos e tecidos linfáticos como linfonodos, baço e placas de Peyer também são afetados, apresentando edema e hemorragia no parênquima (VARASCHIN; BARROS; JARVIS, 1998). As lesões microscópicas descritas em bovinos intoxicados experimentalmente, que culminaram com a morte do animal, caracterizaram-se por edema, necrose e desprendimento do epitélio da mucosa do rúmen e do retículo, congestão em baço e nos espaços de Disse do fígado (TOKARNIA; DOBEREINER, 1976; VARASCHIN; BARROS; JARVIS, 1998). A necrose dos linfonodos foi um achado consistente em experimento realizado com bovinos intoxicados experimentalmente por "mio-mio". Neste estudo realizado por Varaschin e colaboradores (1998), observou-se a ocorrência de necrose mais intensamente em 
folículos secundários. A necrose foi caracterizada pela presença de células com citoplasma eosinofílico e núcleo picnótico ou em cariorrexia. A necrose também foi observada em baço, placas de Peyer e acúmulos linfóides da submucosa do duodeno.

$\mathrm{Na}$ intoxicação experimental de camundongos, realizada com folhas de $B$. coridifolia dessecada, em fase de brotação, a dose letal foi observada a partir de $5 \mathrm{~g} / \mathrm{kg}$ (VARASCHIN, 2002). Ainda, nesta mesma pesquisa, verificou-se que o início das manifestações clínicas ocorreu ao redor de 12 horas, sendo o período de tempo entre a administração da planta e a morte dos animais entre 14 e 300 horas. Os resultados obtidos neste estudo demonstram que os camundongos é a-espécie mais resistente à intoxicação por esta planta.

Nos achados macroscópicos dos camundongos que vieram a óbito com a intoxicação no estudo conduzido por Varaschin (2002), observou-se desidratação de moderada a grave em todos os animais. Além disso, o autor relata a presença de conteúdo sanguinolento no intestino delgado de alguns animais, bem como aumento no volume dos linfonodos. $\mathrm{Na}$ análise microscópica dos órgãos destes camundongos, pode ser observada a necrose acentuada do centro germinativo dos folículos secundários dos linfonodos de alguns animais, enquanto que em outros, foi constatada a hiperplasia reacional dos centros germinativos, associada à presença de macrófagos ao longo dos seios subcapsular, cortical e medular. No baço de alguns camundongos também se observou necrose dos folículos secundários e o timo se apresentava com necrose evidente. Ainda, em relação a esta pesquisa, um achado importante se refere ao estudo imunohistoquímico dos órgãos linfóides dos animais, no qual evidenciou que os linfócitos $B$ são mais afetados pela ingestão da planta do que os linfócitos $T$.

Quanto aos princípios ativos da $B$. coridifolia, estes foram isolados e identificados como sendo os tricotecenos macrocíclicos. A roridina $A$ e roridina $E$ são os principais tricotecenos da planta e representam $0,09 \%$ do peso deste vegetal dessecado. Os outros compostos contidos na B.coridifolia são do mesmo grupo e foram denominados miotoxina $A, B, C, D$ e $F$; isomiotoxina $D$ e os biologicamente inativos miofitocenos $A$ e B (HABERMEHL et al., 1985). A roridina $D$; as verrucarinas $A$ e $\mathrm{J}$ e seus glicosídeos também foram isolados (JARVIS et al., 1987, 1988). 


\subsection{SOBRE OS TRICOTECENOS MACROCÍCLICOS}

Os constituintes químicos dos vegetais se dividem em dois grandes grupos, os metabólitos primários que estão associados à produção de celulose, lignina, proteínas, lipídios, açúcares e outras substâncias que realizam suas principais funções vitais e o chamado metabolismo secundário, do qual resultam substâncias de baixo peso moleculares às vezes produzidas em pequenas quantidades. No metabolismo secundário das plantas há a biossíntese de estruturas complexas como alcalóides, terpenóides e fenilpropanóides. Os metabólitos secundários são formados por vários caminhos biossintéticos que produzem moléculas dotadas de grande diversidade de esqueletos carbônicos e grupamentos funcionais.

Os tricotecenos são potentes micotoxinas e têm sido isolados de uma grande variedade de fungos comuns ao solo. Estes fungos crescem na rizosfera das plantas, que absorvem as micotoxinas e as incorporam em seu sistema, como ocorre na $B$. coridifolia. Os tricotecenos são derivados terpênicos, que são metabólitos secundários das plantas e de fungos. A biogênese dos terpenóides nas plantas ocorre pela via do mevalonato e constituem uma grande variedade de substâncias vegetais derivadas do isopreno. A unidade isoprênica origina-se a partir do ácido mevalônico que é formado pela condensação de uma unidade de acetoacetil-CoA com uma molécula da acetilCoA, a partir da glicose. O grupo dos tricotecenos apresenta um anel sesquiterpenóide (possuem 15 carbonos-3 unidades isoprênicas) em comum, e podem ser classificados de acordo com a presença ou ausência de grupos funcionais característicos associados a este anel. Sendo assim, podem ser divididos em dois grupos: os tricotecenos simples, como o diacetoxiscipernol, a toxina T-2, o verrucarol, o tricodermol; e os tricotecenos macrocíclicos, como a roritoxina $B$; a mirotoxina $B$; as roridinas $A, D, E$; as verrucarinas A e J, os bacarinóides B4, B5 e B12 e 16-Hidroxiverrucarina A (UENO, 1983; JARVIS et al., 1987). Fungos do gênero Fusarium são os maiores produtores dos tricotecenos simples, enquanto os fungos Stachybotrys atra, Myrothecium roridum e Myroyhecium verrucaria são os mais importantes produtores dos tricotecenos macrocíclicos (UENO, 1983). 
Todos os tricotecenos apresentam uma função química epóxido na posição dos carbonos 12,13, a qual é responsável por sua atividade tóxica. Os tricotecenos macrocíclicos apresentam um anel macrocíclico associado ao anel sesquiterpenóide, na posição dos carbonos quatro e cinco (SUDAKIN, 2003).

Quanto ao mecanismo de ação destes compostos, sabe-se que se ligam a subunidade $60 \mathrm{~s}$ do ribossomo interagindo com a enzima peptdiltransferase. Esta interação leva a inibições variáveis das ligações peptídicas dependendo da estrutura química de cada tricoteceno. O grupamento epóxido é necessário para inibição da síntese protéica, e a variação das estruturas associadas ao anel sesquiterpenóide acarretam em efeitos adicionais variáveis (SUDAKIN, 2003).

Foi demonstrado que a redução do grupo epóxido dos tricotecenos ocorre no trato gastrointestinal de ratos, bovinos e suínos (SWANSON et al., 1988), Sendo a eliminação de meia-vida curta em ratos (cerca de 30 minutos). Em bovinos e suínos a meia-vida de eliminação ocorre dentro de $3-5$ horas (ROTTER; PRELUSKY; PESTKA, 1996), o maior tempo de contato com a mucosa gástrica e intestinal em bovinos faz com que haja maior incidência de edema e hemorragia do trato gastrointestinal nesta espécie, quando comparada à murina (VARASCHIN et al., 2002).

Tem sido relatado que os tricotecenos possuem várias propriedades biológicas, algumas delas muito desejáveis, como atividade antibiótica, antiviral e antileucêmica; por outro lado, apresentam também e ação imunotóxica (KUPCHAN et al., 1977; JARVIS et al., 1988; ISAKA et al., 1999; HUGHES et al., 1989; GARCIA et al., 2002). Doses orais de $10 \mathrm{mg} / \mathrm{kg}$ da toxina T-2 em camundongos resultaram na apoptose de linfócitos em timo, linfonodos mesentéricos e placas de Peyer (NAGATA et al., 2001). Ainda em relação à toxina $\mathrm{T}-2$, a menor dose capaz de provocar alterações no sistema imune de suínos, foi de 0,029mg/kg/dia (RAFAl et al., 1995).

Em tecidos humanos, foi relatado a citotoxicidade em megacariócitos e em progenitores eritróides e mielóides em estudo in vitro (FROQUET; SIBIRIL; PARENTMASSIN, 2001). Em estudo realizado com cultura de linfócitos humanos, verificou-se que a exposição destas células a baixas doses de tricotecenos, promoveu aumento da produção de imunoglobulinas. Entretanto, quando da exposição a altas doses de tricotecenos, houve decréscimo da produção das imunoglobulinas (THUVANDER; WIKMAN; GADHASSON, 1999). 
Em relação aos tricotecenos macrocíclicos, trabalhos recentes realizados in vitro demonstraram que as roridinas e as verrucarinas, princípios ativos da $B$. coridifolia, induzem à produção de interleucina IL-2 e IL-6, também do fator de necrose tumoral $\alpha$ (TNF- $\alpha$ ) e promove ainda apoptose em tecido linfóide (CHUNG; JARVIS; PESTKA, 2003). Além disto, em outro estudo realizado por Ueno et al., 1995, foi observado que alguns tricotecenos macrocíclicos induziram apoptose de células leucêmicas promielóticas humanas.

\subsection{PRINCÍPIOS ATIVOS DE PLANTAS E SEUS POTENCIAIS USOS TERAPÊUTICOS}

O emprego de plantas com finalidades terapêuticas há muito tempo ocorre, podendo até mesmo ter contribuído para o desenvolvimento da humanidade. Há relatos de que o povo Sumério há mais de 4.000 a.C., já empregava algumas plantas com atividade farmacológica, como a Papaver somniferum (papoula), de onde se obtinha o ópio para minorar e/ou abolir a dor. A indústria farmacêutica sempre utilizou estas plantas empregadas na medicina "popular" com o objetivo de isolar os princípios ativos das mesmas para emprego terapêutico, sendo vasta a gama de exemplos de princípios ativos obtidos de plantas e que são empregados amplamente na medicina, como a atropina extraída da Atropa belladona, os digitálicos extraídos da Digitallis purpurae entre tantos outros.

Atualmente, descobrir novas moléculas ou novas estratégicas terapêuticas tem se ampliado muito devido à busca crescente da cura do câncer e de outras doenças como aquelas auto-imunidades. Tal fato não tem ocorrido apenas dentro da medicina humana, mas também na veterinária, uma vez que, além da melhora no método diagnóstico, a sobrevida de animais domésticos aumentou significantemente, particularmente naqueles de companhia, e com ela surgiram tais doenças.

Dentre as neoplasias que acometem tanto o ser humano quanto os animais domésticos, está o linfoma ou linfossarcoma, que é um tumor que se origina em 
órgão hematopoiético sólido, como linfonodos, baço ou fígado (COUTO, 1992). Essa é a neoplasia hematopoiética mais comumente relatada em cães, perfazendo aproximadamente $90 \%$ dos casos, com prevalência anual de 24/100.000 (MOULTON; HARVEY, 1990).

Inúmeros são os protocolos propostos para o tratamento de pacientes com linfoma, sendo a ciclofosfamida, um quimioterápico alquilante, um dos medicamentos mais empregados para esta finalidade (WITHROW; MACEWEN, 2007). Porém, à semelhança de outros medicamentos antineoplásicos, há diversos efeitos indesejáveis, tais como mielotoxicidade, náuseas, fraqueza, queda de pêlos, dentre outros e; além disto, deve-se considerar que, mesmo com o tratamento, o prognóstico nem sempre é favorável.

Os variáveis efeitos citotóxicos dos tricotecenos incitam a maiores investigações para a avaliação destes metabólitos como possíveis candidatos a agentes terapêuticos no tratamento do câncer. Portanto, sabendo-se que os tricotecenos macrocíclicos da $B$. coridifolia possuem atividade citotóxica sobre linhagens de células linfóides, o objetivo do presente trabalho foi o de investigar se o uso do extrato desta planta, in vivo, em doses sabidamente não tóxicas, seja de forma isolada ou associado à ciclofosfamida, poderia vir a contribuir como potencial arsenal terapêutico no tratamento de neoplasias de origem linfóide, os linfomas. 
Cobjetivos 


\section{OBJETIVOS}

\subsection{OBJETIVO GERAL}

Verificar se a administração do extrato da $B$. coridifolia, isoladamente ou em associação com a ciclofosfamida promoveria melhora clínica em camundongos portadores de linfoma.

\subsection{OBJETIVOS ESPECÍFICOS}

- Determinar a toxicidade de diferentes extratos e doses da B. coridifolia em camundongos.

- Padronizar e estabilizar, in vitro, o linfoma A20, o qual foi inoculado nos animais experimentais.

- Avaliar a atividade dos extratos de B. coridifolia em esplenócitos, timócitos e células tumorais de Ehrlich e linfoma A20.

- Avaliar os efeitos do resíduo hexânico $(\mathrm{RH})$ de $B$. coridifolia em camundongos portadores de linfoma.

- Determinar quimicamente a presença de tricotecenos macrocíclicos na $B$. coridifolia. 
Materiais e Métodos 


\section{MATERIAIS E MÉTODOS}

\subsection{ANIMAIS}

Foram camundongos de três diferentes linhagens. Na primeira etapa do estudo foram empregados animais, machos, da linhagem Balb/C e Swiss, com 60 dias de idade, pesando entre 25-35g, provenientes do Biotério do Departamento de Patologia da Faculdade de Medicina Veterinária e Zootecnia da Universidade de São Paulo (FMVZ/USP).

$\mathrm{Na}$ segunda etapa, foram empregados camundongos nude, os quais apresentam falha do desenvolvimento do timo, sendo nomeados de camundongos atímicos. Nestes camundongos a aplasia do timo leva a uma síndrome de efeitos pleiotrópicos como a ausência de pêlos, deficiência da função reprodutiva e da competência do sistema imune (ausência de linfócitos T). Foram utilizados camundongos nude fêmeas em condições Specific Pathogen Free (SPF), com 60 dias de idade, pesando entre 15 e $20 \mathrm{~g}$, provenientes do Biotério do Departamento de Patologia da FMVZ/USP.

Durante todo o experimento, os animais das três diferentes linhagens permaneceram em caixas de policarbonato, em número máximo de 05 animais por caixa. As caixas foram forradas com maravalha, sendo os animais mantidos em sala com aeração, exaustão e climatização controladas, com temperatura entre 22 e $24^{\circ} \mathrm{C}$, umidade relativa de $55 \%$ e ciclo de luz noite/dia de $12 \mathrm{~h}$, recebendo ração balanceada e água ad libitum). O presente projeto foi aprovado pelo comitê de Bioética da FMVZ/USP (protocolo número 1300/2008).

\subsection{DROGAS E REAGENTES}

Os principais reagentes e drogas utilizadas durante esse relatório foram: ácido acético (Synth), azul de Trypan (Gibco), cloreto de sódio (Nuclear), clorofórmio 
(Nuclear), EDTA 1mM (Sigma), meio RPMI (Gibco), metanol (Synth), penicilina e estreptomicina (Gibco), solução de formalina a 4\%, soluções de PBS e PBS glicosado (Sigma), solução de $\mathrm{NaCl}$ a 0,9\%, tripsina (Life Technologies), soro bovino fetal (Gibco), xilazina (Anasedan $\AA-V e t b r a n d s)$ e cetamina, (Dopalen $\AA$-Vetbrands), Limulus Amebocyte Lysate (LAL) test (Charles River Endosafe ${ }^{\circledR}$, U.S. License No. 1197) Charles River Laboratories, Inc. (Charleston, SC).

\subsection{MATÉRIA VEGETAL}

As folhas de $B$. coridifolia foram coletadas em uma propriedade da região de Pelotas (RS), nos períodos de fevereiro e setembro de 2008. Após secagem total, foram trazidas para o Departamento de Patologia FMVZ/USP, sendo mantidas em freezer regulado para a temperatura de $-20^{\circ} \mathrm{C}$ até o momento da produção dos extratos da $B$. coridifolia.

\subsection{PROCEDIMENTOS}

Foram realizados procedimentos para obtenção de diferentes extratos de Baccharis coridifolia, análise química e ensaios biológicos com os extratos obtidos.

3.4.1 Obtenção dos extratos da B. coridifolia

Os extratos de $B$. coridifolia foram preparados de duas maneiras: o EB, como proposto por Varaschin (2002), e o EE, a partir de processo de rotoevaporação adaptado em nosso laboratório. Os processos para a obtenção dos extratos são descritos a seguir: 


\section{a) Obtenção de Extrato Bruto (EB):}

Foram preparadas duas soluções a partir de duas amostras diferentes, uma solução preparada com amostra coletada em fevereiro de 2008, composta de talos e folhas (EB1) e outra solução preparada com amostra coletada em setembro de 2008, composta por folhas (EB2). Para o preparo das soluções, a planta foi triturada e moída em liquidificador com água destilada, foi então obtida uma solução-mãe a partir da amostra da B.coridifolia que continha altas concentrações de talos junto às folhas secas/mL (EB1) e outra amostra, na qual se verificava pouca concentração de talos junto às folhas secas/mL (EB2). As soluções foram mantidas no congelador $\left(-20^{\circ} \mathrm{C}\right)$, até imediatamente o momento de seu uso, quando foram preparadas para serem administradas aos camundongos.

\section{b) Obtenção de Extrato Etanólico (EE):}

Foram preparadas duas soluções a partir de duas amostras diferentes, uma solução preparada com amostra coletada em fevereiro de 2008, composta basicamente por talos e uma pequena quantidade de folhas (EE1); e outra solução obtida a partir de amostra da planta, coletada em setembro de 2008, sendo esta amostra composta somente por folhas (EE2).

As amostras coletadas foram preparadas separadamente, sendo trituradas em um liquidificador e maceradas com álcool etílico $95 \%$ durante três dias. A solução obtida foi filtrada e acondicionada em balão volumétrico para posterior rotaevaporação. $O$ resíduo vegetal restante foi submetido à nova extração com álcool etílico $95 \%$, sendo este processo repetido por quatro vezes, sempre utilizando o mesmo resíduo vegetal obtido das folhas e/ou talos macerados. As soluções obtidas foram concentradas com um rotoevaporador sob pressão reduzida à $50^{\circ} \mathrm{C}$ para eliminar o solvente (álcool etílico $95 \%$ ). Os extratos secos obtidos (EE1 e EE2) foram mantidos sob temperatura $-20 \div \mathrm{C}$ até o preparo da solução-mãe.

c) Obtenção do Resíduo Hexânico $(\mathrm{RH})$ :

O EE2 foi submetido à extração com hexano e posteriormente filtrado, resultando em dois resíduos: resíduo solúvel em hexano $(\mathrm{RH})$ e resíduo insolúvel em 
hexano $(\mathrm{RIH})$. O RH obtido foi mantido sob temperatura $-20^{\circ} \mathrm{C}$ até o preparo da solução-mãe.

Possíveis contaminações dos extratos por endotoxinas foram verificadas com o teste Limulus Amebocyte Lysate (Charles River Endosafe ${ }^{\circledR}$, U.S. License No. 1197). Os níveis de endotoxina encontrados em ambas as amostras foram inferiores a 0, 125 $\mathrm{UE} / \mathrm{mL}$, um valor que corresponde ao limite de detecção do ensaio, demonstrando, portanto, que os extratos obtidos não apresentaram contaminação por endotoxinas em níveis capazes de alterar os resultados experimentais de testes biológicos ou in vitro.

3.4.2 Identificação dos tricotecenos macrocíclicos no extrato etanólico de $B$. coridifolia

Os extratos etanólicos (EE1 e EE2) de B. coridifolia foram diluídos de duas maneiras: primeiramente com água (1), para obtenção das frações mais polares, e posteriormente com hexano (2), para obtenção das frações mais apolares: 1) Diluição do EE com água e filtração, obtendo-se dois resíduos: resíduo insolúvel em água (RIA) e a solução aquosa (SA). A solução aquosa foi extraída sucessivamente com acetato de etila, onde se obteve o resíduo acetato de etila (RAE), e posteriormente foi extraída com butanol saturado com água, onde se obteve o resíduo butanólico (RB) e o resíduo aquoso final (RA). 2) Diluição do EE com hexano, obtendo-se dois resíduos: resíduo hexânico $(\mathrm{RH})$ e resíduo insolúvel em hexano $(\mathrm{RIH})$. O resíduo insolúvel em hexano foi diluído em diclorometano, obtendo-se dois novos resíduos: resíduo insolúvel em diclorometano (RID) e resíduo diclorometano (RD). O fluxograma é apresentado no item resultados.

Foi realizada a análise cromatográfica dos resíduos obtidos previamente. Primeiramente foi utilizada cromatografia em camada delgada (TLC), tendo como fase estacionária sílica-gel placa 60F e como fase móvel clorofórmio (93): acetona (7). Posteriormente utilizou-se como fase móvel clorofórmio (9): metanol (1). Também foi realizada análise bidimensional do EE de $B$. coridifolia pelo método de cromatografia de 
alta resolução (HPTLC), utilizando-se como fase móvel 1- clorofórmio (93): acetona (7) e 2- clorofórmio (9): metanol (1). Como solução reveladora foi utilizada $\mathrm{H}_{2} \mathrm{SO}_{4} 10 \%$.

3.4.3 Identificação dos tricotecenos macrocíclicos no Resíduo Hexânico de B. coridifolia

\section{a. Cromatografia em coluna}

Os RHs obtidos do EE1 e EE2 foram submetidos a duas colunas de fracionamento em sílica gel: coluna 01 (EE1) e coluna 02(EE2). Para tanto, 30g de sílica gel $60 \mathrm{H}$ (1077361000-Merck) foi solubilizada com o mesmo eluente (fase móvel) utilizado na corrida: clorofórmio (93): acetona (7). Foram utilizados $400 \mathrm{ml}$ de eluente para fase móvel. Utilizou-se $300 \mathrm{mg}$ de $\mathrm{RH}$ para a corrida, sob média pressão. Foram coletadas 40 frações de $6 \mathrm{ml}$ para coluna 01 e 70 frações de $03 \mathrm{~mL}$ para coluna 02 . As frações obtidas da coluna 01 foram nomeadas em ordem numérica de 1.0 a 1.40 como $\mathrm{BC} 1$, as frações obtidas da coluna 02 foram nomeadas em ordem numérica de $2.0 \mathrm{a}$ 2.70 como BC2.

\section{b. Cromatografia em camada delgada}

As frações $\mathrm{BC} 1$ e $\mathrm{BC} 2$ foram submetidas à cromatografia em camada delgada (TLC), tendo como fase estacionária sílica-gel placa 60F e como fase móvel clorofórmio (93): acetona (7). Juntamente com as frações utilizou-se na corrida amostra do RH e padrão sitosterol (esteróide) para comparação dos índices de retenção (Rf). As frações de $\mathrm{BC} 1$ também foram reunidas e posteriormente submetidas à cromatografia em camada delgada da seguinte maneira:

BC1. 0 = Fração $A$

BC1. 1-1.4=Fração $B$

BC 1.5-1.8=Fração $C$

BC 1.9-1.11=Fração $D$

BC 1.12-1.13=Fração E
BC 1.14-1.22= Fração $F$

BC 1.23-1.26=Fração $G$

$B C$ 1.27-1.29=Fração $H$

BC 1.30-1.34=Fração I

BC 1.35-1.40=Fração J 
3.4.4 Administração dos extratos aos animais

\section{a. Extrato Bruto (EB) e Etanólico (EE)}

A administração do extrato bruto foi feita por via oral, através de gavage, nas doses de 0,$1 ; 0,3 ; 1,0 ; 2,0$ e $3,0 \mathrm{~g} / \mathrm{kg}$, durante 21 dias. As soluções foram preparadas imediatamente antes da administração, diluindo-se o extrato em água destilada. $A$ solução de EE1 foi obtida, diluindo-se o extrato em uma mistura água-óleo de girassol, para permitir a sua melhor dissolução. Administrou-se o EE1 aos camundongos na dose de $2,0 \mathrm{~g} / \mathrm{kg}$, durante sete dias.

\section{b. Resíduo Hexânico (RH)}

A administração do resíduo hexânico foi feita por via oral, por meio de gavage, na dose de $0,5 \mathrm{~g} / \mathrm{kg}$, durante 07 dias. A solução foi preparada imediatamente antes da administração, diluindo-se o $\mathrm{RH}$ em água-tween $20 \AA$ para permitir a sua melhor dissolução.

3.4.5 Ganho de peso dos animais

Os animais foram pesados antes do início do delineamento e depois, a cada dois dias, para avaliação do ganho de peso dos mesmos e adequação das doses a serem administradas.

3.4.6 Manutenção do linfoma A20 in vitro

As células do linfoma A20 foram adquiridas do banco de células ATCC (American Type Culture Collection), por intermédio do banco de células do Rio de 
Janeiro (Cell Bank RJ) e foram mantidas em cultura em meio RPMI-1640 enriquecido com $10 \%$ de soro fetal bovino (SFB) estéril em concentração de aproximadamente 1,0 x $10^{6}$ células $/ \mathrm{mL}$ por garrafa de cultura, em estufa umidificada a $37^{\circ} \mathrm{C}$ e $5 \% \mathrm{CO}_{2}$.

3.4.7 Manutenção do tumor de Ehrlich in vivo

O tumor ascítico de Ehrlich vem sendo mantido in vivo no biotério do Departamento de Patologia da Faculdade de Medicina Veterinária-USP, por sucessivas passagens sob crescimento intraperitoneal em camundongos BALB-c e Swiss.

3.4.8 Contagem global das células da medula óssea

As células da medula óssea foram obtidas da cavidade femoral de cada animal, após a lavagem da mesma com $5,0 \mathrm{~mL}$ de solução resfriada de RPMI (ajustada no ph de 7,4$)$. As células foram acondicionadas em tubos cônicos de $15 \mathrm{~mL}$ e dispersas com auxílio de pipeta tipo Pasteur até se obter uma suspensão celular homogênea. Posteriormente, $10 \mu \mathrm{L}$ desta amostra foram colhidos e diluídos na razão de 1:100 em Azul de Trypan (diluído 6x em PBS). A viabilidade e contagem global das células nucleadas foram realizadas em câmara de Neubauer.

3.4.9 Hemograma, bioquímica e peso relativo do baço e timo

Ao término do tratamento com $B$. coridifolia todos os animais foram anestesiados com xilazina $(8 \mathrm{mg} / \mathrm{kg})$ e cetamina $(60 \mathrm{mg} / \mathrm{kg})$ por via i.p., para coleta de sangue por punção intracardíaca, em eppendorfs de $1,5 \mathrm{~mL}$ contendo EDTA 10\%. Em seguida, 
realizou-se o hemograma em aparelho automatizado (Vet ABC Animal Blood Counter, Horiba ABX Diagnostics). Após separação do plasma foi realizada dosagem das enzimas: Alanina Aminotransferase (ALT), Uréia, Creatinina, Proteina Total, Albumina, e Gama Glutamil Transferase (GGT) em aparelho automatizado (Bioplus Bio 200F). Imediatamente após a coleta do sangue realizou-se a coleta do baço e timo para o cálculo de peso relativo.

\subsubsection{Avaliação histopatológica}

Após o período experimental, os animais foram submetidos à eutanásia para avaliação macroscópica de possíveis lesões e para coleta dos seguintes órgãos: fígado, baço, placas de Peyer, timo, linfonodos mesentéricos, pulmão, rins e tumor subcutâneo. Estes tecidos foram fixados em formol (10\%) e emblocados em parafina e, posteriormente, as lâminas foram coradas pela técnica de hematoxilina e eosina (HE).

Estas lâminas histopatológicas foram observadas em microscópio de luz, acoplado com a máquina fotográfica Nikon DXM 1200c; para análise das imagens foi usado o programa IMAGE PRO PLUS ${ }^{\circledR}$.

\subsubsection{Inoculação do linfoma A20 em camundongos nude}

As células tumorais de linfoma A20 foram cultivadas previamente em meio RPMI1640 enriquecido com $10 \%$ de soro fetal bovino (SFB) estéril em concentração de aproximadamente $1,0 \times 10^{6}$ células $/ \mathrm{mL}$ por garrafa de cultura, em estufa umidificada a $37^{\circ} \mathrm{C}$ e $5 \% \mathrm{CO}_{2}$, até que atingissem a concentração ideal de $5 \times 10^{6}$ células $/ \mathrm{mL}$. Os animais foram inoculados sob condições estéreis em fluxo laminar, subcutaneamente na região entre as escápulas, com $0,2 \mathrm{~mL}$ de solução salina estéril contendo $1 \times 10^{6}$ células. Os animais foram mantidos no biotério em condições SPF até que os tumores fossem palpáveis ou atingissem o mínimo de $10 \mathrm{~mm}$ na medida do diâmetro maior. 
3.4.12 Padronização das células tumorais A20, esplenócitos e timócitos in vitro

Para padronização do número de células A20 a serem utilizadas em estudos posteriores in vitro, as células tumorais linfóides foram plaqueadas em quadruplicatas em duas diferentes placas de 96 wells (placa 1 e placa 2), nas concentrações de $1 \times 10^{7}$ cél $/ \mathrm{ml} ; 1 \times 10^{6} \mathrm{cé} / \mathrm{ml} ; 1 \times 10^{5} \mathrm{cél} / \mathrm{ml} ; 1 \times 10^{4}$ cél $/ \mathrm{ml}$ e $1 \times 10^{3}$ cél $/ \mathrm{ml}$ em meio RPMl-1640 enriquecido com $10 \%$ de soro fetal bovino (SFB) estéril. Como controle negativo foi plaqueado apenas o meio de cultura utilizado, na mesma concentração. As células plaqueadas foram mantidas em estufa umidificada a $37^{\circ} \mathrm{C}$ e $5 \% \quad \mathrm{CO}_{2}$, durante respectivamente 24horas (placa1) e 48horas (placa 2). Após o período de incubação respectivo para cada placa, adicionou-se $10 \mu \mathrm{l}$ do reagente MTT (ATCC número 30$1010 \mathrm{~K})$ em cada poço e incubou-se novamente em estufa umidificada a $37^{\circ} \mathrm{C}$ e $5 \%$ $\mathrm{CO}_{2}$, durante 3horas. Após este período foi adicionado $100 \mu \mathrm{l}$ de álcool isopropílico acidificado $(10 \%$ em $\mathrm{HCl} 0,01 \mathrm{~N})$ e mantiveram-se as placas durante 1hora em temperatura ambiente abrigadas da luz. Os cristais de tetrazólio formados foram dissolvidos mecanicamente com pipeta, em seguida as placas foram analisadas em espectrofotômetro (Pharmacia Biotek Ultrospec 3000, UV/Visible Spectophotometer) na absorbância de 570nm. O ensaio de MTT se baseia na redução deste sal pelas células metabolicamente ativas, por meio das enzimas desidrogenases presentes nas mitocôndrias. Estas enzimas catalisam a reação dos íons $\mathrm{H}^{+}$liberados pela reação dos tecidos vivos com o sal (2, 3,5 - trifenil cloreto de tetrazólio), formando uma substância de cor roxa-azulada, estável e não difusível denominada trifenilformazan. Se o sal de tetrazólio é reduzido, formando o composto roxo, houve atividade respiratória nas mitocôndrias, significando que há viabilidade celular e do tecido. Os tecidos não viáveis não reagem e, conseqüentemente, não formam estes cristais. Para cada concentração de células cultivadas, foram obtidas diferentes quantidades da formação do sal de tetrazólio, permitindo assim sua quantificação por meio de análise colorimétrica no espectrofotômetro (Pharmacia Biotek Ultrospec 3000, UV/Visible Spectophotometer) na absorbância de 570nm.

Para padronização das células presentes no baço (esplenócitos) e no timo (timócitos) os órgãos foram coletados de três camundongos BALB/c. Os órgãos foram 
macerados e a solução de células foi lavada com solução de PBS tamponada por três vezes. O precipitado de células foi ressuspendido em meio de cultura RPMI-1640 enriquecido com $10 \%$ de soro fetal bovino (SFB) estéril. As células foram plaqueadas em quadruplicatas em três diferentes placas de 96 wells (placa 1,2 e 3), nas concentrações de $1 \times 10^{7} \mathrm{cél} / \mathrm{ml} ; 1 \times 10^{6} \mathrm{cél} / \mathrm{ml} ; 1 \times 10^{5} \mathrm{cél} / \mathrm{ml} ; 1 \times 10^{4} \mathrm{cél} / \mathrm{ml}$ e $1 \times 10^{3} \mathrm{cél} / \mathrm{ml}$. Como controle negativo foi plaqueado apenas o meio de cultura utilizado, na mesma concentração. As células plaqueadas foram mantidas em estufa umidificada a $37^{\circ} \mathrm{C} \mathrm{e}$ $5 \% \mathrm{CO}_{2}$, durante 24 horas, posteriormente foram realizados os mesmos procedimentos utilizados para as células A20, para realização da técnica de MTT.

3.4.13 Cultivo celular de linfoma A20, esplenócitos e timócitos sob tratamento com Extrato Etanólico2 e resíduo hexânico de $B$. coridifolia

Culturas em quadruplicatas de células de linfoma A20, esplenócitos e timócitos foram incubadas $\left(8 \times 10^{5}\right.$ células $\left./ \mathrm{ml}\right)$ com as seguintes concentrações de $E E$ e RH: 10 $\mathrm{mg} / \mathrm{ml}, 1 \mathrm{mg} / \mathrm{ml}, 100 \mu \mathrm{g} / \mathrm{ml}$ e $10 \mu \mathrm{g} / \mathrm{ml}$. As soluções foram preparadas a partir de uma solução de $100 \mathrm{mg} / \mathrm{mL}$ dos extratos diluídos em água destilada e DMSO 0,1\% e posteriormente filtradas em microfiltros (Minisart®) em fluxo laminar. As células plaqueadas foram mantidas em estufa umidificada a $37^{\circ} \mathrm{C}$ e $5 \% \mathrm{CO}_{2}$, durante 24 horas, posteriormente foram realizados os procedimentos utilizados para realização da técnica de MTT. 
3.4.14 Cultivo celular de linfoma A20, tumor de Ehrlich, esplenócitos e timócitos sob tratamento com resíduo hexânico de $B$. coridifolia

Linfócitos normais foram obtidos a partir de três camundongos BALB/C e Swiss (baço e timo) e as células tumorais empregadas foram as linhagens: linfoma A20 e carcinoma de Ehrlich

Culturas em quadruplicatas para cada linhagem de células $\left(8 \times 10^{5}\right.$ células $\left./ \mathrm{ml}\right)$ foram realizadas da seguinte maneira: células não tratadas e tratadas com $\mathrm{RH} 1 \mathrm{mg} / \mathrm{ml}$; com incubação de $24 \mathrm{~h}$ em $37^{\circ} \mathrm{C}$ em atmosfera húmida, contendo $5 \%$ de CO2 até doseamento por MTT. O amarelo tetrazólio MTT (3-(4, 5-dimethylthiazolyl-2)-2, 5diphenyltetrazolium brometo) é reduzido por células metabolicamente ativas. $\mathrm{O}$ cristal púrpura intracelular resultante foi dissolvido e quantificado por meio espectrofotométrico (Pharmacia Biotek Ultrospec 3000, Spectophotometer de UV/visível) na absorção de $570 \mathrm{~nm}$.

\subsection{ANÁLISE ESTATÍSTICA}

Para a análise estatística, foi utilizado o software GraphPad Instat v3. 01, e os resultados obtidos foram apresentados na forma de média e seu respectivo desvio-padrão. Foi realizado o teste estatístico $T$ não pareado, para dados paramétricos entre dois grupos, sendo utilizado o teste Mann-Whitney para dados não paramétricos entre dois grupos avaliados. Para análise de dados entre mais de dois grupos, foram utilizados os testes de Kruskall- Wallis ou ANOVA. No caso de dados paramétricos, foi utilizada a análise de variância ANOVA para comparação das médias entre os vários grupos. Para detecção das diferenças significantes entre os grupos, após a ANOVA, foi empregado o teste de Tukey-Kramer para avaliação estatística entre todos os grupos de animais. Para análise de dados não paramétricos utilizou-se o teste de Kruskall, seguido do pós-teste de Dunn. 


\section{DELINEAMENTO EXPERIMENTAL E RESULTADOS}

\subsection{EXPERIMENTO 1 - AVALIAÇÃO DA TOXICIDADE DOS EXTRATOS BRUTOS E ETANÓLICOS DE B. CORIDIFOLIA}

Para avaliação da toxicidade dos extratos brutos (EB1 e EB2) foram utilizados quatro camundongos Swiss para cada dose de extrato utilizado. Três outros animais de mesma linhagem foram tratados com água destilada (grupo controle). Para avaliação da toxicidade de EB2 também foram empregados quatro camundongos Balb/C para cada dose. Os animais dos grupos experimentais receberam por via oral, através de gavage, uma única dose de EB1 ou EB2, a saber: 10; 8; 6 e $4 \mathrm{~g} / \mathrm{kg}$. Os camundongos provenientes do grupo controle receberam apenas água no volume calculado, de acordo com a fórmula:

volume de administração $(\mathrm{mL})=\frac{\text { Peso do animal }(\mathrm{g})}{100}$.

Para avaliação dos extratos etanólicos (EE1 e EE2) foram utilizados quatro camundongos Swiss para cada dose de extrato utilizado, e três camundongos tratados com água destilada-óleo de girassol (grupo controle). Para avaliação da toxicidade de EE2 também foram utilizados quatro camundongos Balb/c para cada dose utilizada no grupo tratado. Os animais dos grupos experimentais receberam dose única de EE1 ou EE2, nas doses de 10; 8; 6 e $4 \mathrm{~g} / \mathrm{kg}$, por via oral. Os camundongos provenientes do grupo controle receberam apenas água destilada-óleo de girassol no volume calculado de acordo com a fórmula:

volume de administração $(\mathrm{mL})=\frac{\text { Peso do animal }(g)}{100}$.

Após a administração dos diferentes tratamentos, todos os animais foram observados por 48 horas e avaliados segundo a sintomatologia clínica apresentada após a administração dos extratos. 


\subsubsection{Resultados Experimento 01}

O EB1, composto por talos e folhas de B. coridifolia daquelas plantas coletadas em fevereiro de 2008 e que foram administradas a camundongos da linhagem Swiss, mostrou possuir toxicidade, promovendo letalidade nos camundongos na dose de 10 $\mathrm{g} / \mathrm{kg}$. As outras doses de EB1 não promoveram sintomatologia clínica após administração em dose única.

Já a administração do EE dos talos e folhas (EE1) produziu morte nos animais a partir da dose de $8 \mathrm{~g} / \mathrm{kg}$. Antes dos animais virem a óbito, estes se apresentavam apáticos, desidratados, com pêlos arrepiados e fezes amolecidas. Os demais animais tratados com outras doses deste extrato, embora tivessem sobrevivido, mostraram sintomas de apatia e pêlos arrepiados, evoluindo para recuperação espontânea. Os resultados estão apresentados na tabela 1.

A administração do EB2 composto por folhas dessecadas de B. coridifolia, as quais foram coletadas em setembro de 2008, demonstrou ser letal a partir da dose de $8 \mathrm{~g} / \mathrm{kg}$, sendo que os demais animais, cuja administração foi menor que $8 \mathrm{~g} / \mathrm{kg}$, não exteriorizaram nenhuma sintomatologia clínica após administração deste extrato. Por outro lado, O EE2 das folhas dessecadas revelou a partir da dose de $4 \mathrm{~g} / \mathrm{kg}$. A sintomatologia apresentada por aqueles animais que no final vieram a óbito foi muito semelhante àquela observada nos animais do experimento de toxicidade relatado anteriormente. Os resultados estão apresentados na tabela 1. 
Tabela 1 - Avaliação da toxicidade de diferentes doses dos extratos brutos (EB1 e EB2) e etanólicos (EE1 e EE2) da $B$. coridifolia administrados em camundongos Swiss e $\mathrm{BALB} / \mathrm{C}$, tratados uma única vez e observados durante 48 horas subseqüentes.

\section{Tratamento}

(doses)

\begin{tabular}{cccccccccccccc}
\hline & \multicolumn{4}{c}{$10 \mathrm{~g} / \mathrm{kg}^{\mathrm{a}}$} & \multicolumn{4}{c}{$8 \mathrm{~g} / \mathrm{kg}^{\mathrm{a}}$} & \multicolumn{3}{c}{$6 \mathrm{~g} / \mathrm{kg}^{\mathrm{a}}$} & \multicolumn{3}{c}{$4{\mathrm{~g} / \mathrm{kg}^{\mathrm{a}}}^{\text {Extrato }}$} & Peso & Morte & Tempo & Peso & Morte & Tempo & Peso & Morte & Tempo & Peso & Morte* & Tempo \\
& $(\mathrm{g})$ & $(+/-)$ & $(\mathrm{h})$ & $(\mathrm{g})$ & $(+/-)$ & $(\mathrm{h})$ & $(\mathrm{g})$ & $(+/-)$ & $(\mathrm{h})$ & $(\mathrm{g})$ & $(+/-)$ & $(\mathrm{h})$ \\
EB1 & 34,2 & + & 36 & 35,0 & - & - & 32 & - & - & 30 & - & - \\
EE1 & 34,3 & + & 24 & 31,6 & + & 24 & 32,8 & - & - & 34,0 & - & - \\
EB2 & 34,2 & + & 36 & 35,0 & + & 30 & 32,0 & - & - & 30 & - & - \\
EE2 & 34,3 & + & 22 & 31,6 & + & 24 & 32,8 & + & 26 & 34 & + & 25 \\
& & & & & & & & & & & & \\
\hline
\end{tabular}

${ }^{\mathrm{a}} \mathrm{n}=4$ camundongos/tratamento

* Intervalo de tempo para a ocorrência de morte.

EB1: extrato bruto de talos e folhas de B. coridifolia; EE1: extrato etanólico de talos e folhas de B. coridifolia; EB2: extrato bruto de folhas dessecadas de $B$. coridifolia; EE2: extrato etánólico de folhas dessecadas de $B$. coridifolia.

\subsection{EXPERIMENTO 2 - AVALIAÇÃO DA TOXICIDADE DO RESÍDUO HEXÂNICO DE B. CORIDIFOLIA ADMINISTRADO EM CAMUNDONGOS NUDE}

Foram utilizados quatro animais nude para cada dose da solução aquosa de $\mathrm{RH}$ testada: $2 \mathrm{~g} / \mathrm{kg}, 1 \mathrm{~g} / \mathrm{kg}$ e $0,5 \mathrm{~g} / \mathrm{kg}$. Todos os animais receberam as respectivas doses por via oral, através de gavage, de acordo com o peso, com volume calculado por meio da fórmula:

$$
\text { volume de administração }(\mathrm{mL})=\frac{\text { Peso do animal }(g)}{100} \text {. }
$$

Após a administração dos diferentes tratamentos, todos os animais foram observados por 48 horas avaliando-se a sintomatologia clínica apresentada. 


\subsubsection{Resultados Experimento 02}

$\mathrm{O} \mathrm{RH}$, obtido a partir do EE2 de $B$. coridifolia, demonstrou efeito letal a partir da dose de $1 \mathrm{~g} / \mathrm{kg}$. A administração da dose de $0,5 \mathrm{~g} / \mathrm{kg}$ deste resíduo não provocou nenhuma alteração comportamental ou manifestação clínica. Os animais dos grupos tratados com as doses de $2 \mathrm{~g} / \mathrm{kg}$ e $1 \mathrm{~g} / \mathrm{k}$, apresentaram-se apáticos após $4 \mathrm{~h}$ da administração; após 8h estes animais mostravam sinais de desidratação com pêlos arrepiados e fezes amolecidas. Todos os animais que receberam a dose de $2 \mathrm{~g} / \mathrm{kg}$ vieram a óbito, sendo que dois dos quatro animais daquele grupo tratado com $1 \mathrm{~g} / \mathrm{kg}$ quatro morreram.

Tabela 2 - Avaliação da toxicidade de diferentes doses do $\mathrm{RH}$ da B. coridifolia sobre camundongos nude, tratados, por via oral, uma única vez e observados durante 48 horas subseqüentes.

\begin{tabular}{|c|c|c|c|c|c|c|c|c|c|}
\hline \multirow[b]{3}{*}{ Extrato } & \multicolumn{9}{|c|}{$\begin{array}{c}\text { Tratamento } \\
\text { (doses) }\end{array}$} \\
\hline & \multicolumn{3}{|c|}{$2 \mathrm{~g} / \mathrm{kg}^{\mathrm{a}}$} & \multicolumn{3}{|c|}{$1 \mathrm{~g} / \mathrm{kg}^{\mathrm{a}}$} & \multicolumn{3}{|c|}{$0,5 \mathrm{~g} / \mathrm{kg}^{\mathrm{a}}$} \\
\hline & $\begin{array}{l}\text { Peso } \\
(\mathrm{g})\end{array}$ & $\begin{array}{l}\text { Morte } \\
(+/-)\end{array}$ & $\begin{array}{c}\text { Tempo } \\
\text { (h) }\end{array}$ & $\begin{array}{l}\text { Peso } \\
(\mathrm{g})\end{array}$ & $\begin{array}{l}\text { Morte } \\
(+/-)\end{array}$ & $\begin{array}{c}\text { Tempo } \\
\text { (h) }\end{array}$ & $\begin{array}{l}\text { Peso } \\
(\mathrm{g})\end{array}$ & $\begin{array}{l}\text { Morte } \\
(+/-)\end{array}$ & $\begin{array}{c}\text { Tempo } \\
\text { (h) }\end{array}$ \\
\hline RH & 18 & + & 14 & 35,0 & + & 24 & 18,4 & - & - \\
\hline
\end{tabular}




\subsection{EXPERIMENTO 3 - TRATAMENTO DE CAMUNDONGOS BALB/C E SWISS COM SOLUÇÕES DE EXTRATO BRUTO (EB) E EXTRATO ETANÓLICO (EE1) DE B. CORIDIFOLIA}

\section{a. Extrato Bruto (EB)}

Para avaliação da toxicidade do extrato bruto (EB1) foram utilizados cinco camundongos Swiss para cada dose de extrato utilizado, e cinco camundongos tratados com água destilada (grupo controle). Os animais dos grupos experimentais receberam diariamente EB1, nas doses de $0,1 \mathrm{~g} / \mathrm{kg}, 0,3 \mathrm{~g} / \mathrm{kg}, 1,0 \mathrm{~g} / \mathrm{kg}, 2,0 \mathrm{~g} / \mathrm{kg}$ ou $3,0 \mathrm{~g} / \mathrm{kg}$, via oral, por 21 dias. Os camundongos provenientes do grupo controle receberam apenas água destilada no volume calculado de acordo com a fórmula:

$$
\text { volume de administração }(\mathrm{mL})=\frac{\text { Peso do } \operatorname{animal}(g)}{100} \text {. }
$$

Após os animais terem sido submetidos à eutanásia, utilizando para tal anestesia profunda com quetamina-xilazina, procedeu-se à coleta dos órgãos: baço e timo, os quais foram pesados, bem como fígado, rins, cérebro, linfonodos mesentéricos, placas de Peyer e medula óssea, para análise histopatológica, conforme descrito no item 3.4.10. Avaliou-se ainda a celularidade de medula óssea e o perfil hematológico conforme descrito nos itens 3.4 .8 e 3.4.9, respectivamente.

\section{b. Extrato Etanólico (EE1)}

Foram utilizados 10 camundongos $B A L B / c$ divididos em dois grupos, em um deles os animais foram tratados com a solução etanólica da $B$. coridifolia, e no outro os cinco camundongos receberam apenas água-óleo de girassol (grupo controle). Os animais tratados com a planta receberam o volume calculado de acordo com a fórmula: volume de administração $(\mathrm{mL})=\frac{\text { Peso do animal }(g)}{100}$, de solução etanólica (EE1ou EE2) emulsificada de $B$. coridifolia, na dose de $2,0 \mathrm{~g} / \mathrm{kg}$, via oral por meio de gavage, por sete dias. Após a eutanásia dos animais, realizou-se procedimento idêntico àquele descrito no experimento anterior. A seguir, coletaram-se os órgãos: baço e timo, os quais foram 
também pesados, bem como fígado, rins, cérebro, linfonodos mesentéricos, placas de Peyer e medula óssea para análise histopatológica, conforme item 3.4.10. Foi avaliada ainda a celularidade de medula óssea e o perfil hematológico destes animais segundo descrito nos itens 3.4 .8 e 3.4 .9 , respectivamente.

\subsubsection{Resultados Experimento 03}

\section{a. Extrato Bruto (EB)}

A tabela 6 mostra que não foram observadas alterações na celularidade da medula óssea; além disso, não foram detectadas alterações hematológicas nos animais de ambos os grupos, em relação aos animais do grupo controle (Tabela 5). Em relação ao ganho de peso dos camundongos tratados com as diferentes doses da solução aquosa do EB, a análise de variância empregada (ANOVA), não evidenciou qualquer diferença estatisticamente significante $(p>0,05)$ entre os valores obtidos nos diferentes grupos de animais, conforme pode ser observado na tabela 3. Da mesma forma, este mesmo teste estatístico não revelou qualquer diferença significante entre os grupos, nos parâmetros: peso relativo de órgãos linfóides (timo e baço), celularidade de medula óssea e análise hematológica (Tabelas $3,4,5$ e 6). Na tabela 7 os dados foram analisados, por meio do teste Kruskall-Wallis, seguido do teste de Dunn. Não foram observadas alterações histopatológicas dos órgãos coletados: baço, timo, fígado, rins, cérebro, linfonodos mesentéricos, placas de Peyer e medula óssea. 
Tabela 3 - $\quad$ Peso (em gramas) dos camundongos tratados com solução aquosa de $B$. coridifolia (EB1) nas doses de 0,$1 ; 0,3 ; 1,0 ; 2,0$ e 3,0 g/kg ou água (grupo controle), por gavage, após 21 dias de tratamento

\begin{tabular}{cc}
\hline Grupos & Peso(g) \\
\hline Controle & $35,0 \pm 0,7$ \\
$0,1 \mathrm{~g} / \mathrm{kg}$ & $34,2 \pm 2,7$ \\
$0,3 \mathrm{~g} / \mathrm{kg}$ & $31,6 \pm 1,8$ \\
$1,0 \mathrm{~g} / \mathrm{kg}$ & $33,1 \pm 1,0$ \\
$2,0 \mathrm{~g} / \mathrm{kg}$ & $33,8 \pm 1,1$ \\
$3,0 \mathrm{~g} / \mathrm{kg}$ & $33,7 \pm 0,9$ \\
\hline
\end{tabular}

Dados representados por média \pm desvio-padrão. $N=5$

Tabela 4 - Peso relativo (em gramas/100 gramas de peso vivo) de baço e timo coletados dos camundongos tratados com solução aquosa de $B$. coridifolia (EB1) nas doses de 0,$1 ; 0,3 ; 1,0 ; 2,0$ e $3,0 \mathrm{~g} / \mathrm{kg}$ ou água (grupo controle), por gavage, após 21 dias de tratamento

\begin{tabular}{lcc}
\hline $\begin{array}{c}\text { Grupos } \\
(\mathbf{n}=\mathbf{5})\end{array}$ & $\begin{array}{c}\text { Timo } \\
\left(\mathbf{g} / \mathbf{1 0 0 g} \mathbf{~ p v} \mathbf{a}^{\mathbf{a}}\right)\end{array}$ & $\begin{array}{c}\text { Baço } \\
\left(\mathbf{g} / \mathbf{1 0 0 g} \mathbf{~ p v} \mathbf{a}^{\mathbf{a}}\right.\end{array}$ \\
\hline Controle & $0,06 \pm 0,01$ & $0,24 \pm 0,03$ \\
$0,1 \mathrm{~g} / \mathrm{kg}$ & $0,04 \pm 0,02$ & $0,36 \pm 0,08$ \\
$0,3 \mathrm{~g} / \mathrm{kg}$ & $0,07 \pm 0,02$ & $0,34 \pm 0,07$ \\
$1,0 \mathrm{~g} / \mathrm{kg}$ & $0,08 \pm 0,01$ & $0,32 \pm 0,05$ \\
$2,0 \mathrm{~g} / \mathrm{kg}$ & $0,06 \pm 0,01$ & $0,28 \pm 0,04$ \\
$3,0 \mathrm{~g} / \mathrm{kg}$ & $0,06 \pm 0,01$ & $0,29 \pm 0,07$ \\
\hline Dados representados por média \pm desvio-padrão. ${ }^{2} \mathrm{pv}=$ peso vivo
\end{tabular}


Tabela 5 - Análise Hematológica. Número de hemácias, leucócitos e plaquetas $/ \mathrm{mm}^{3}$ de sangue de camundongos tratados com solução aquosa de $B$. coridifolia (EB1) nas doses de 0,$1 ; 0,3 ; 1,0 ; 2,0$ e 3,0 g/kg ou água (grupo controle), por gavage, após 21 dias de tratamento

\begin{tabular}{cccc}
\hline $\begin{array}{c}\text { Grupos } \\
(\mathbf{n}=\mathbf{5})\end{array}$ & $\begin{array}{c}\text { Hemácias } \\
\left(\mathbf{\times 1 0 ^ { 6 }} / \mathbf{m m}^{\mathbf{3}}\right)\end{array}$ & $\begin{array}{c}\text { Leucócitos } \\
\left(\mathbf{\times 1 0 ^ { 3 }} / \mathbf{m m}^{\mathbf{3}}\right)\end{array}$ & $\begin{array}{c}\text { Plaquetas } \\
\mathbf{( \times 1 0} \mathbf{3}\end{array}$ \\
\hline Controle & $8,7 \pm 0,3$ & $3,6 \pm 1,0$ & $733,0 \pm 62,4$ \\
$0,1 \mathrm{~g} / \mathrm{kg}$ & $8,2 \pm 0,4$ & $3,2 \pm 0,7$ & $808,0 \pm 73,7$ \\
$0,3 \mathrm{~g} / \mathrm{kg}$ & $8,4 \pm 1,2$ & $3,5 \pm 1,2$ & $796,0 \pm 39,5$ \\
$1,0 \mathrm{~g} / \mathrm{kg}$ & $8,3 \pm 0,2$ & $3,7 \pm 0,9$ & $799,8 \pm 37,4$ \\
$2,0 \mathrm{~g} / \mathrm{kg}$ & $8,6 \pm 0,4$ & $3,9 \pm 0,6$ & $791,8 \pm 73,7$ \\
$3,0 \mathrm{~g} / \mathrm{kg}$ & $8,7 \pm 0,3$ & $3,2 \pm 1,0$ & $764,3 \pm 63,9$ \\
\hline
\end{tabular}

Dados representados por média \pm desvio-padrão

Tabela 6 - Celularidade da medula óssea de camundongos tratados com solução aquosa de $B$. coridifolia (EB1) nas doses de 0,$1 ; 0,3 ; 1,0 ; 2,0$ e $3,0 \mathrm{~g} / \mathrm{kg}$ ou água (grupo controle), por gavage, após 21 dias de tratamento

\begin{tabular}{|c|c|}
\hline $\begin{array}{l}\text { Grupos } \\
(n=5)\end{array}$ & $\begin{array}{l}\text { Celularidade da Medula Óssea } \\
\qquad\left(\times 10^{7}\right)\end{array}$ \\
\hline Controle & $2,69 \pm 5,6$ \\
\hline $0,1 \mathrm{~g} / \mathrm{kg}$ & $2,64 \pm 7,9$ \\
\hline $0,3 \mathrm{~g} / \mathrm{kg}$ & $3,01 \pm 7,9$ \\
\hline $1,0 \mathrm{~g} / \mathrm{kg}$ & $2,62 \pm 6,1$ \\
\hline $2,0 \mathrm{~g} / \mathrm{kg}$ & $2,64 \pm 2,8$ \\
\hline $3,0 \mathrm{~g} / \mathrm{kg}$ & $3,10 \pm 4,6$ \\
\hline
\end{tabular}

Dados representados por média \pm desvio-padrão 
Tabela7- Análise diferencial do esfregaço sanguíneo. Porcentagem de neutrófilos segmentados, linfócitos, monócitos e eosinófilos de camundongos tratados com solução aquosa de $B$. coridifolia (EB1) nas doses de 0,$1 ; 0,3 ; 1,0 ; 2,0$ e 3,0 g/kg ou água (grupo controle), por gavage, após 21 dias de tratamento

\begin{tabular}{ccccc}
\hline $\begin{array}{c}\text { Grupos } \\
(\mathbf{n}=\mathbf{5})\end{array}$ & $\begin{array}{c}\text { Segmentados } \\
(\%)\end{array}$ & $\begin{array}{c}\text { Linfócitos } \\
(\%)\end{array}$ & $\begin{array}{c}\text { Monócitos } \\
(\%)\end{array}$ & $\begin{array}{c}\text { Eosinófilos } \\
(\%)\end{array}$ \\
\hline Controle & $16,0 \pm 2,4$ & $75,8 \pm 4,0$ & $7,0 \pm 2,2$ & $1,2 \pm 1,3$ \\
$0,1 \mathrm{~g} / \mathrm{kg}$ & $16,2 \pm 2,5$ & $78,0 \pm 3,3$ & $4,6 \pm 2,3$ & $1,2 \pm 1,3$ \\
$0,3 \mathrm{~g} / \mathrm{kg}$ & $18,2 \pm 5,1$ & $75,0 \pm 5,4$ & $6,0 \pm 1,4$ & $0,7 \pm 0,9$ \\
$1,0 \mathrm{~g} / \mathrm{kg}$ & $13,5 \pm 5,4$ & $81,0 \pm 6,4$ & $4,5 \pm 1,9$ & $1,0 \pm 0,8$ \\
$2,0 \mathrm{~g} / \mathrm{kg}$ & $15,2 \pm 4,6$ & $79,2 \pm 6,8$ & $5,0 \pm 2,5$ & $0,6 \pm 0,8$ \\
$3,0 \mathrm{~g} / \mathrm{kg}$ & $14,6 \pm 4,2$ & $78,6 \pm 5,4$ & $6,0 \pm 1,5$ & $0,8 \pm 1,3$ \\
\hline
\end{tabular}

Dados representados por média \pm desvio-padrão

\section{b. Extrato Etanólico (EE1)}

Em relação ao ganho de peso dos animais, a análise estatística não revelou alterações significantes, segundo o teste empregado $(p>0,05$; teste $T)$, quando se comparou os dados obtidos dos animais tratados com EE1, com aqueles dos animais do grupo controle (Tabela 8). Também não houve alteração na celuraridade da medula óssea dos animais tratados em relação aos animais controle (Tabela 10).

Ainda, não foram detectadas alterações entre os valores obtidos dos camundongos tratados com EE1 e aqueles dos animais do grupo controle, no que se refere ao peso relativo do baço; entretanto, foram observadas variações significantes no peso relativo do timo (Tabela 9, Figura 1) dos animais tratados com 2,0 g/kg do EE1 de B. Coridifolia, em relação aos animais do grupo controle $(p=0,04$; teste $T)$.

$\mathrm{Na}$ avaliação hematológica (Tabela 11 e Figura 2), foi observado aumento significante no número total de leucócitos ( $p=0,03$; teste de Mann-Whitney) e de plaquetas $(p=0,02$; teste $T)$, nos animais tratados com EE1 em relação aos animais do grupo controle. Na contagem diferencial do esfregaço sanguíneo (Tabela 12, Figura 3) dos animais tratados com 2,0 $\mathrm{g} / \mathrm{kg}$ do EE1 de $B$. Coridifolia observou-se uma diminuição na porcentagem de linfócitos ( $p<0,01$; teste de Mann-Whitney) e um aumento na 
porcentagem de neutrófilos segmentados ( $p=0,04$; teste de Mann-Whitney), comparativamente com os animais controle. A avaliação histopatológica dos órgãos não evidenciou alterações.

Tabela 8 - Peso (em gramas) de camundongos Balb/C, após sete dias de tratamento com solução emulsificada do extrato etanólico (EE1) de B. coridifolia, na dose de 2,0 $\mathrm{g} / \mathrm{kg}$, ou água+óleo de girassol (grupo controle), por via oral, através de gavage

\begin{tabular}{cc}
\hline Grupos $(\mathrm{n}=5)$ & Peso $(\mathbf{g})$ \\
\hline Controle & $32,5 \pm 2,1$ \\
$2,0 \mathrm{~g} / \mathrm{kg}$ & $29,6 \pm 2,2$ \\
\hline
\end{tabular}

Dados representados por média \pm desvio-padrão

Tabela 9- Peso relativo (em gramas/100gramas de peso vivo) de baço e timo coletados dos camundongos Balb/C após sete dias de tratamento com solução emulsificada do extrato etanólico (EE1) de B. coridifolia, na dose de 2,0 g/kg, ou água+óleo de girassol (grupo controle), por via oral, através de gavage

\begin{tabular}{|c|c|c|}
\hline $\begin{array}{c}\text { Grupos } \\
(n=5)\end{array}$ & $\begin{array}{c}\text { Timo } \\
\left(g / 100 g p^{a}\right)\end{array}$ & $\begin{array}{c}\text { Baço } \\
\left(g / 100 g p^{a}\right)\end{array}$ \\
\hline Controle & $0,10 \pm 0,01$ & $0,32 \pm 0,02$ \\
\hline $2,0 \mathrm{~g} / \mathrm{kg}$ & $0,06 \pm 0,01^{*}$ & $0,32 \pm 0,04$ \\
\hline
\end{tabular}

Dados representados por média \pm desvio-padrão. ${ }^{*} \mathrm{p}=0,004 \mathrm{~T}$ Test. ${ }^{\mathrm{a}} \mathrm{pv}=$ peso vivo 


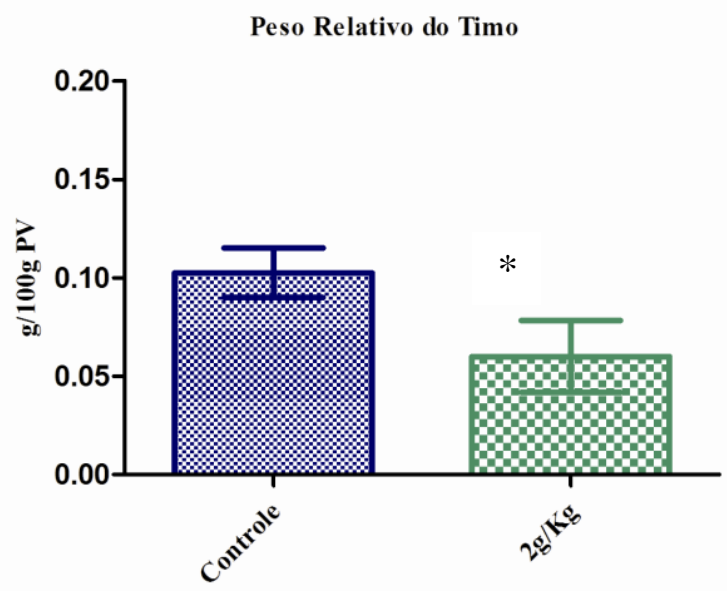

Figura 1 - Peso relativo do timo coletado dos camundongos Balb/C após sete dias de tratamento com solução emulsificada do extrato etanólico (EE1) de B. coridifolia, na dose de 2,0 g/kg, ou água+óleo de girassol (grupo controle), por via oral, através de gavage. * $\mathrm{p}=0,004 \mathrm{~T}$ Test

Tabela10 - Celularidade da medula óssea de camundongos Balb/C após sete dias de tratamento com solução emulsificada do extrato etanólico (EE1) de $B$. coridifolia, na dose de $2,0 \mathrm{~g} / \mathrm{kg}$, ou água+óleo de girassol (grupo controle), por via oral, através de gavage.

\begin{tabular}{|c|c|}
\hline $\begin{array}{l}\text { Grupos } \\
(n=5)\end{array}$ & $\begin{array}{l}\text { Celularidade da Medula Óssea } \\
\qquad\left(\times 10^{7}\right)\end{array}$ \\
\hline Controle & $4,5 \pm 0,9$ \\
\hline $2,0 \mathrm{~g} / \mathrm{kg}$ & $5,0 \pm 0,6$ \\
\hline
\end{tabular}

Dados representados por média \pm desvio-padrão 
Tabela 11- Análise hematológica. Número de hemácias, leucócitos, plaquetas, hematócrito $(\mathrm{Ht})$, e hemoglobina $(\mathrm{Hb})$ de sangue de camundongos Balb/C após sete dias de tratamento com solução emulsificada do extrato etanólico (EE1) de B. coridifolia, na dose de 2,0 g/kg, ou água+óleo de girassol (grupo controle), por via oral, através de gavage.

\begin{tabular}{|c|c|c|c|c|c|}
\hline $\begin{array}{l}\text { Grupos } \\
(n=5)\end{array}$ & $\begin{array}{l}\text { Hemácias } \\
\left(\times 10^{6} / \mathrm{mm}^{3}\right)\end{array}$ & $\begin{array}{l}\mathrm{Ht} \\
(\%)\end{array}$ & $\begin{array}{c}\mathrm{Hb} \\
(\mathrm{g} / \mathrm{dL})\end{array}$ & $\begin{array}{l}\text { Leucócitos } \\
\left(\times 10^{3} / \mathrm{mm}^{3}\right)\end{array}$ & $\begin{array}{c}\text { Plaquetas } \\
\left(\times 10^{3}\right)\end{array}$ \\
\hline Controle & $8,9 \pm 0,6$ & $39,7 \pm 3,1$ & $13,7 \pm 1,0$ & $3,9 \pm 0,9$ & $633 \pm 72,5$ \\
\hline $2 \mathrm{~g} / \mathrm{kg}$ & $8,3 \pm 0,2$ & $35,8 \pm 1,1$ & $13,0 \pm 0,4$ & $4,9 \pm 1,2^{x}$ & $746 \pm 104,1^{\pi \pi}$ \\
\hline
\end{tabular}

a)

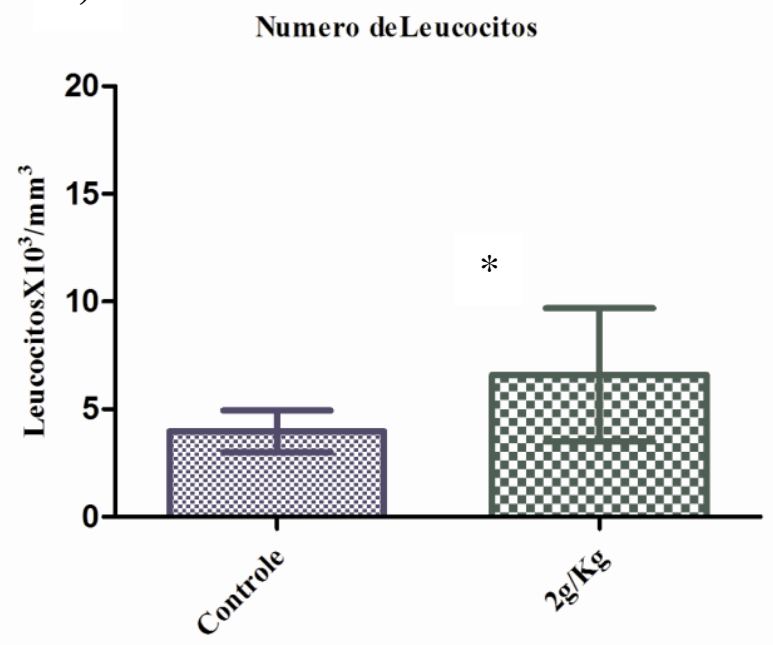

b)

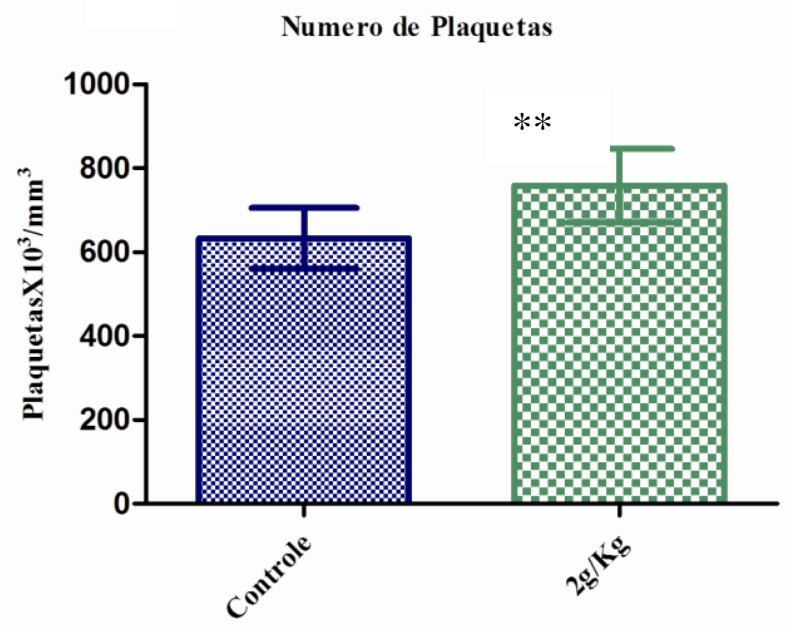

Figura 2- Análise hematológica de camundongos tratados com solução emulsificada do extrato etanólico (EE1) de B. coridifolia, na dose de 2,0g/kg, ou água+óleo de girassol (grupo controle), por gavage, após sete dias de tratamento. a) *Número de leucócitos por $\mathrm{mm}^{3}$ de sangue. b) **Número de plaquetas por $\mathrm{mm}^{3}$ de sangue. $\mathrm{p}=0,10 \mathrm{~T}$ Teste; ${ }^{*} \mathrm{p}=$ 0, 003 Mann Whitney Test. ${ }^{* *} p=0,002$ T Teste 
Tabela 12- Análise diferencial do esfregaço sanguíneo. Porcentagem de neutrófilos segmentados, linfócitos, monócitos e eosinófilos de camundongos tratados com solução emulsificada do extrato etanólico (EE1) de B. coridifolia, na dose de 2,0 g/kg, ou água+óleo de girassol (grupo controle), por gavage, após sete dias de tratamento

\begin{tabular}{ccccc}
\hline $\begin{array}{c}\text { Grupos } \\
(\mathbf{n}=\mathbf{5})\end{array}$ & $\begin{array}{c}\text { Segmentados } \\
\mathbf{( \% )}\end{array}$ & $\begin{array}{c}\text { Linfócitos } \\
\mathbf{( \% )}\end{array}$ & $\begin{array}{c}\text { Monócitos } \\
\mathbf{( \% )}\end{array}$ & $\begin{array}{c}\text { Eosinófilos } \\
(\%)\end{array}$ \\
\hline Controle & $21,6 \pm 2,3$ & $77,6 \pm 2,4$ & $0,8 \pm 0,2$ & $0 \pm 0$ \\
$2,0 \mathrm{~g} / \mathrm{kg}$ & $41,5 \pm 6,8^{*}$ & $56,3 \pm 7,9^{* \times}$ & $1,6 \pm 1,4$ & $0,1 \pm 0,4$ \\
\hline
\end{tabular}

Dados representados por média \pm desvio-padrão. $p=0,0002$ T Test; * $p=0,004$ Mann Whitney Test. $p=0,0003$

T Test; ${ }^{* *} p<0,001$ Mann Whitney Test

a)

Contagem Diferencial de Linfócitos

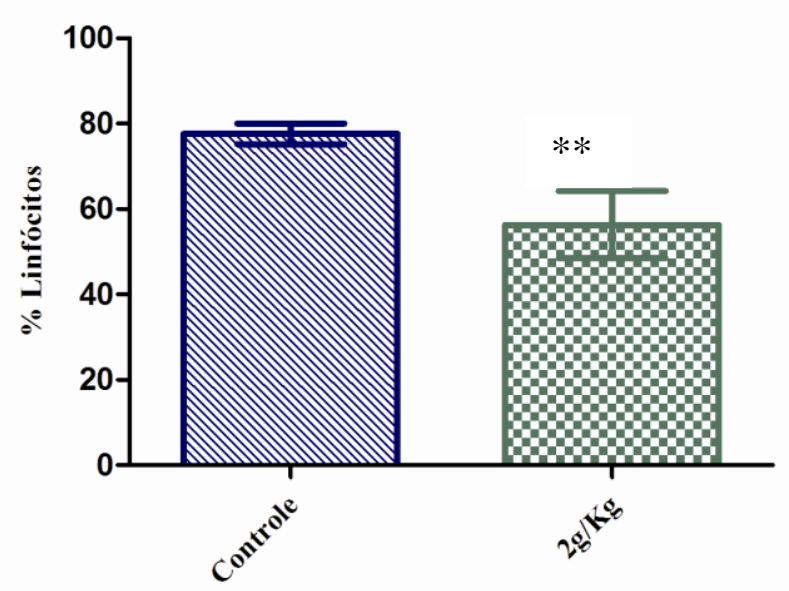

b)

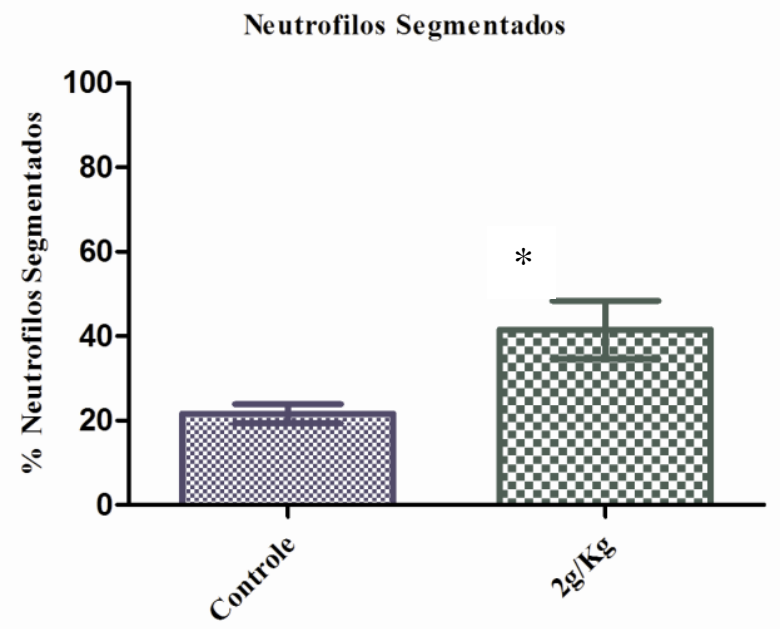

Figura 3- Análise diferencial do esfregaço sanguíneo de camundongos tratados com solução emulsificada do extrato etanólico (EE1) de B. coridifolia, na dose de 2,0 g/kg, ou água+óleo de girassol (grupo controle), por via oral, através de gavage, após sete dias de tratamento. a) ${ }^{* *}$ Porcentagem de linfócitos. b) *Porcentagem de neutrófilos segmentados. $p=0,0002$ T Teste; ${ }^{*} p=0,004$ Mann Whitney Test. $p=0,0003 \mathrm{~T}$ Teste; ${ }^{* *} p<0,001$ Mann Whitney Teste 


\subsection{EXPERIMENTO 04 - DETERMINAÇÃO DOS VALORES DE REFERÊNCIA PARA PARÂMETROS HEMATOLÓGICOS, BIOQUÍMICOS E HISTOPATOLÓGICOS DE CAMUNDONGOS NUDE}

Foram utilizados 04 camundongos nude fêmeas em condições SPF, com 60 dias de idade, pesando entre 15 e $20 \mathrm{~g}$. Os animais foram submetidos à anestesia para a coleta de amostras de sangue por punção intracardíaca. Após a eutanásia foram coletados órgãos (baço, fígado, rins, pulmão, coração e intestino) para avaliação histopatológica.

\subsubsection{Resultados Experimento 04}

Os dados obtidos pela análise hematológica e bioquímica são apresentados na tabela 13, servindo como parâmetros de normalidade desta linhagem para os camundongos sadios presentes no biotério do Departamento de Patologia da Faculdade de Medicina Veterinária e Zootecnia - USP. Os resultados obtidos na avaliação histopatológica dos órgãos destes animais foram utilizados para análise comparativa com os animais do experimento 05 , portadores de linfoma. 
Tabela 13- Parâmetros hematológicos e bioquímicos de camundongos nude SPF, sadios do biotério do Departamento de Patologia da Faculdade de Medicina Veterinária e Zootecnia - USP

\begin{tabular}{lc}
\hline Parâmetros Hematológicos e Bioquímicos ${ }^{*}$ & $\begin{array}{c}\text { Valores de referência - camundongos nude } \\
\text { Biotério VPT/FMVZ-USP }\end{array}$ \\
\hline Hematócrito & $37-44 \%$ \\
Leucócitos & $6.000-15.000 / \mathrm{mm}^{3}$ \\
Linfócitos & $3600-9000 / \mathrm{mm}^{3}(60 \%)$ \\
Neutrófilos segmentados & $2160-5400 / \mathrm{mm}^{3}(36 \%)$ \\
Monócitos & $240-600 / \mathrm{mm}^{3}(4 \%)$ \\
Plaquetas & $300.000-400.000 / \mathrm{mm}^{3}$ \\
ALT & $30-90$ \\
GGT & $1,2-3,0$ \\
Ureia & $40-80$ \\
Creatinina & $0,4-0,8$ \\
Proteína Total & $5,0-7,0 \mathrm{~g} / \mathrm{dL}$ \\
Albumina & $2,0-4,0$ \\
\hline${ }^{*}=4$ &
\end{tabular}

\subsection{EXPERIMENTO 05 - EFEITO DO RH SOB CAMUNDONGOS NUDE PORTADORES DO LINFOMA A20}

Foram utilizados quatro grupos de sete animais cada, inoculados subcutaneamente na região entre as escápulas com $0,2 \mathrm{~mL}$ de solução salina contendo $1 \times 10^{6}$ células, de acordo com o item 3.4.11. Os animais foram tratados durante sete dias (dia 1 ao dia 7) e submetidos à eutanásia no oitavo dia, após o início da administração, com exceção daqueles camundongos provenientes do grupo controle (A20), que foram mortos no quinto dia. Os grupos de animais foram divididos e tratados da seguinte maneira: 
Grupo controle A20: No dia primeiro do tratamento os animais receberam, por via intraperitoneal (IP), água destilada no volume calculado pela fórmula: $\frac{\text { Peso do animal }(g)}{100}$. Os animais foram tratados com dose única diária de água destilada por gavage oral no volume calculado pela fórmula: $\frac{\text { Pesodo animal }(g)}{100}$, até o quarto dia do tratamento. No quinto dia os animais foram submetidos à eutanásia devido à evolução agressiva do linfoma. Foram acompanhadas as medidas do diâmetro tumoral e peso dos animais durante os dias 1, 2, 3 e 4 do tratamento. Imediatamente antes da eutanásia os animais foram anestesiados e coletaram-se amostras de sangue por punção intracardiaca para análises bioquímicas e hematológicas. Foram coletados os linfonodos mandibulares, axilares, baço, fígado, rins, intestino, pulmão e a formação tumoral para análise histopatológica. Foi determinado o peso do baço após coleta de acordo com a fórmula:

$$
\frac{\text { Peso do baçox100 }}{\text { Peso do animal }}=\text { Peso do baço g/100gPV }
$$

Grupo RH: No dia primeiro do tratamento os animais receberam por via IP água destilada no volume calculado pela fórmula: $\frac{\text { Peso do animal }(g)}{100}$. Os camundongos foram tratados com dose única diária de solução de $\mathrm{RH}$. A dose de $0,5 \mathrm{~g} / \mathrm{kg}$ da solução de $\mathrm{RH}$ $(0,05 \mathrm{~g} / \mathrm{mL})$ foi administrada por via oral, através de gavage, no volume calculado pela fórmula: $\frac{\text { Peso do animal }(\mathrm{g})}{100}$. Um dia após o fim do tratamento os animais foram submetidos à coleta de sangue e órgãos em procedimento idêntico àquele descrito para os animais do grupo controle A20.

Grupo $\mathbf{R H + c i c l o f o s f a m i d a : ~ N o ~ p r i m e i r o ~ d i a ~ d o ~ t r a t a m e n t o ~ o s ~ a n i m a i s ~ r e c e b e r a m , ~ p o r ~}$ via IP, uma inoculação de solução de ciclofosfamida $(20 \mathrm{mg} / \mathrm{mL})$ na dose de $200 \mathrm{mg} / \mathrm{kg}$ no volume calculado pela fórmula: $\frac{\text { Peso do animal }(g)}{100}$. Os camundongos foram tratados com dose única diária de solução de $\mathrm{RH}$, durante sete dias. A dose de $0,5 \mathrm{~g} / \mathrm{kg}$ da solução de $\mathrm{RH}(0,05 \mathrm{~g} / \mathrm{mL})$ foi administrada nas mesmas condições que aquela descrita para os animais do grupo $\mathrm{RH}$. Um dia após o fim do tratamento, coletou-se o sangue e órgãos destes camundongos, conforme procedimento já descrito para aqueles animais dos grupos controle $\mathrm{A} 20$ e $\mathrm{RH}$. 
Grupo ciclofosfamida: No dia primeiro do tratamento os animais receberam por via IP, solução de ciclofosfamida $(20 \mathrm{mg} / \mathrm{mL})$ na dose de $200 \mathrm{mg} / \mathrm{kg}$, no volume calculado pela

fórmula: $\frac{\text { Peso do animal }(g)}{100}$. Os animais foram tratados, durante sete dias, com dose única diária de água destilada, por via oral, através de gavage, no volume calculado de acordo com a fórmula anteriormente apresentada. Um dia após o fim do tratamento os camundongos foram submetidos à coleta de sangue e órgãos.

\subsubsection{Resultados Experimento 05}

$\mathrm{Na}$ avaliação dos parâmetros hematológicos os animais do grupo controle apresentaram diminuição significante no número de plaquetas $(p=0,0002$ ANOVA pós teste Tukey), como apresentado na tabela 14 e figura 04-D. Os camundongos do grupo $\mathrm{RH}-\mathrm{C}$ mostraram número de plaquetas significantemente menor que os animais dos grupos $\mathrm{RH}$ e ciclofosfamida (Tabela 14 e Figura 4-D); porém, estes valores encontramse dentro daqueles de referência para a espécie, comparativamente aos animais nude sadios. Os animais dos grupos $\mathrm{RH}$ e Ciclofosfamida revelaram discreta trombocitose, quando comparados com os valores daqueles nude sadios. Não houve diferenças significantes entre os dados provenientes dos diferentes grupos na análise do número total de leucócitos e absoluto de neutrófilos. Entretanto, a contagem absoluta de linfócitos revelou linfocitose significante ( $p=0,013$ ANOVA pós teste Tukey) naqueles camundongos pertencentes ao grupo controle, comparativamente aos animais tratados (Tabela 14 e Figura 4-C). Além disso, na análise diferencial de esfregaço sanguíneo destes animais foi observada moderada presença de linfócitos atípicos, com características neoplásicas (10\% dos linfócitos observados). Não houve diferenças significantes nos valores de hematócrito dos animais tratados e controle, porém, todos os grupos demonstraram uma discreta diminuição no hematócrito, quando comparados aos animais nude sadios.

Os valores obtidos na variação do diâmetro tumoral entre o início e o final do tratamento demonstram claramente que os animais tratados apresentaram uma 
diminuição no tamanho do linfoma inoculado, sendo que naqueles do grupo $\mathrm{RH}-\mathrm{C}$ houve a maior involução do tumor (Tabela 15). Os dados negativos representam uma diminuição do diâmetro tumoral. Houve crescimento do linfoma inoculado nos animais do grupo controle, representado por valor positivo do diâmetro tumoral (Figura 6). Com relação ao peso relativo do baço (Figura 7), os animais do grupo controle apresentaram valores muito superiores comparativamente aos animais dos grupos tratados $(p=0$, 0001 ANOVA pós teste de Tukey- tabela 15). Quanto à celularidade da medula óssea, não houve diferenças significantes entre os grupos tratados e o grupo controle $(p=0,06)$.

$\mathrm{Na}$ análise de bioquímica do sangue dos animais (Tabela 16), observou-se um aumento na concentração plasmática das enzimas hepáticas: ALT e GGT (Figura 8) nos animais do grupo controle ( $p=0,0001$ - ALT e $p=0,006$ - GGT ANOVA pós teste Tukey). Comparativamente aos camundongos nude sadios, todos os animais dos grupos tratados e controle apresentaram diminuição discreta nos valores de proteína total e albumina.

Quanto às alterações histopatológicas dos órgãos, foram observadas metástases no fígado, baço, linfonodos e pulmão naqueles animais do grupo controle (Quadros 1 a 7). As metástases foram caracterizadas com a presença de linfócitos neoplásicos no órgão. No fígado e baço dos animais dos grupos tratados foi observada discreta quantidade de células polimofonucleares e moderada presença de megacariócitos (Quadros 1 e 2). Os linfonodos dos animais tratados dos grupos $\mathrm{RH}-\mathrm{C}$ e ciclofosfamida não foram coletados, pois não houve aumento de volume destes órgãos. No grupo de camundongos $\mathrm{RH}$ apenas dois animais apresentaram aumento de volume dos linfonodos, com presença de infiltrado neoplásico (Quadro 06). A avaliação histopatológica do tumor dos animais tratados revelou alterações histológicas semelhantes, com presença de infiltrado de células inflamatórias (polimorfonucleares, plasmócitos, mastócitos e histiócitos) e linfócitos neoplásicos (Quadro 7). O grupo tratado $\mathrm{RH}-\mathrm{C}$ apresentou tumor constituído de menor densidade celular e maior presença de necrose. 
Tabela 14 - Parâmetros hematológicos dos camundongos nude SPF, sadios do biotério do Departamento de Patologia da Faculdade de Medicina Veterinária e Zootecnia USP e dos animais dos grupos tratados com resíduo hexânico $(\mathrm{RH})$, resíduo hexânico associado à ciclofosfamida $(\mathrm{RH}-\mathrm{C})$, ciclofosfamida $(\mathrm{C})$ e grupo controle

\begin{tabular}{|c|c|c|c|c|c|}
\hline Itens Avaliados & Controle $^{a}$ & $\mathrm{RH}^{\mathrm{a}}$ & $\mathrm{RH}-\mathrm{C}^{\mathrm{a}}$ & Ciclofosfamida $^{a}$ & $N u d e^{b}$ \\
\hline $\begin{array}{c}\text { Hematócrito } \\
(\%)\end{array}$ & $29,5 \pm 3,8$ & $31 \pm 2$ & $33,5 \pm 1,2$ & $31,4 \pm 2,2$ & $37-44$ \\
\hline Plaquetas $/ \mathrm{mm}^{3}$ & $253.500 \pm 178.000$ & $647.428 \pm 81.236^{*}$ & $442.551 \pm 33.411^{*}$ & $630.285 \pm 22.662^{*}$ & $\begin{array}{l}300.000- \\
400.000\end{array}$ \\
\hline Leucócitos $/ \mathrm{mm}^{3}$ & $13.500 \pm 3.877$ & $8.700 \pm 3.864$ & $9.557 \pm 2.354$ & $7.200 \pm 3.864$ & $\begin{array}{l}6.000- \\
15.000\end{array}$ \\
\hline $\begin{array}{l}\text { Neutrófilos } \\
\text { Segmentados } \\
/ \mathrm{mm}^{3}\end{array}$ & $6211 \pm 2.379$ & $5702 \pm 2.692$ & $6857 \pm 1.693$ & $4961 \pm 1.820$ & $\begin{array}{c}2160- \\
5400(36 \%)\end{array}$ \\
\hline Linfócitos $/ \mathrm{mm}^{3}$ & $7288 \pm 2.291$ & $2998 \pm 1.251^{*}$ & $2699 \pm 712^{*}$ & $2239 \pm 642^{*}$ & $\begin{array}{c}3600- \\
9000(60 \%)\end{array}$ \\
\hline
\end{tabular}

\begin{tabular}{|c|c|}
\hline${ }^{a} N=7$ & Dados representados por média \pm desvio-padrão \\
\hline RH = Resíduo Hexânico & $R H-C=$ resíduo hexânico associado a Ciclofosfamida \\
\hline
\end{tabular}


a)

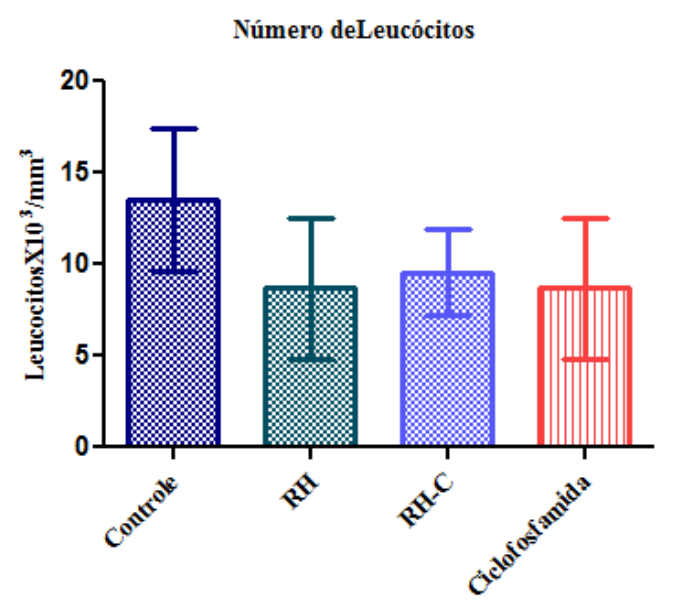

c)

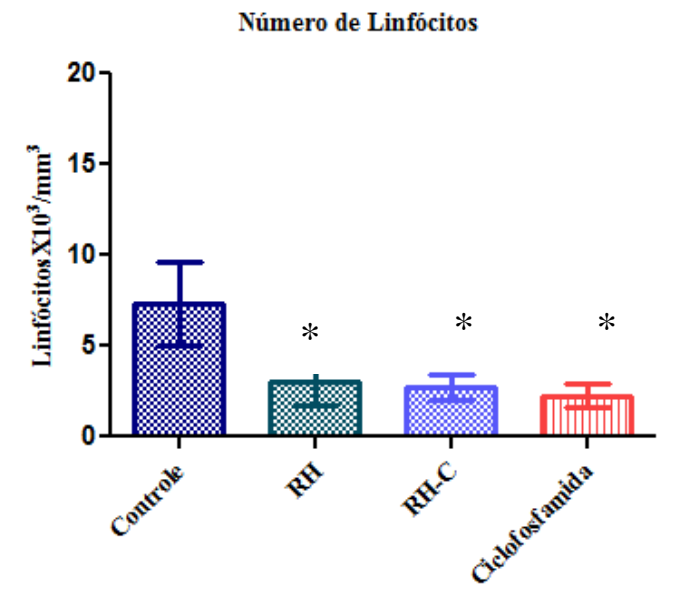

b)

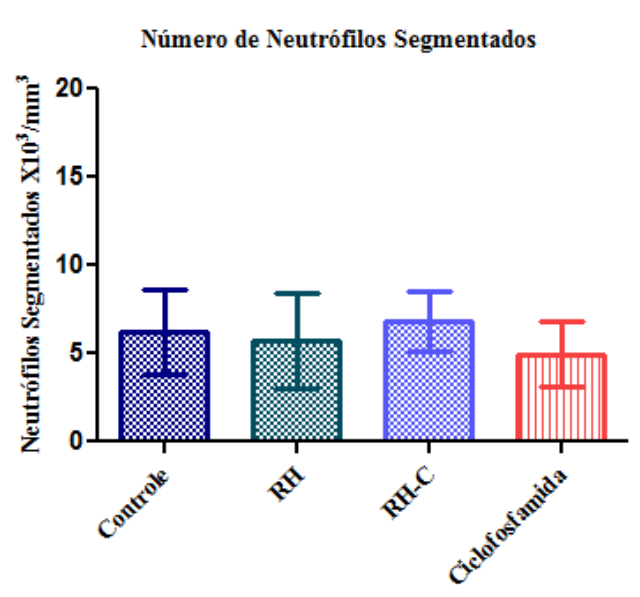

d)

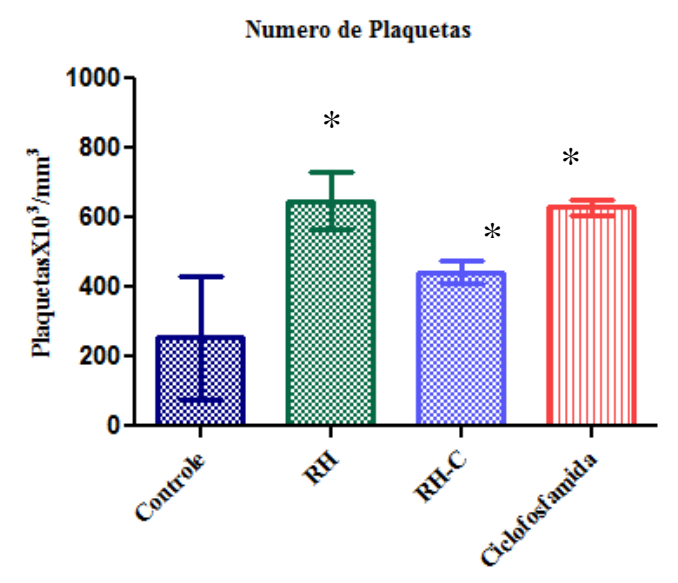

Figura 4- Parâmetros hematológicos de camundongos tratados com resíduo hexânico $(\mathrm{RH})$ de B. coridifolia, na dose de $0,5 \mathrm{~g} / \mathrm{kg}, \mathrm{RH}$ associado à ciclofosfamida ou apenas ciclofosfamida. Como grupo controle: água+Tween20, por via oral, através de gavage, e uma aplicação de água destilada por via intraperitoneal, após sete dias de tratamento. a) Número total de leucócitos b) Número absoluto de neutrófilos segmentados c) Número absoluto de linfócitos " $\mathrm{p}=0,0013$ ANOVA pós teste de Tukey d) Número absoluto de plaquetas * $p=0,0002$ ANOVA pós-teste Tukey 
Tabela 15- Avaliação dos órgãos linfóides e da variação do diâmetro do linfoma A20 dos animais dos grupos tratados com resíduo hexânico $(\mathrm{RH})$, resíduo hexânico associado à ciclofosfamida $(\mathrm{RH}-\mathrm{C})$, ciclofosfamida $(\mathrm{C})$ e grupo controle

\begin{tabular}{ccccc}
\hline Itens Avaliados & Controle & $\mathrm{RH}$ & $\mathrm{RH}-\mathrm{C}$ & Ciclofosfamida \\
\hline Peso relativo do & $4,04 \pm 2,3 \mathrm{~g} / 100 \mathrm{~g}$ & $0,74 \pm 0,1 \mathrm{~g} / 100 \mathrm{~g}$ & $0,84 \pm 0,1 \mathrm{~g} / 100 \mathrm{~g}$ & $0,78 \pm 0,77 \mathrm{~g} / 100 \mathrm{~g}$ \\
Baço & $\mathrm{pv}$ & $\mathrm{PV}^{*}$ & $\mathrm{pv}^{*}$ & $\mathrm{pv}^{*}$ \\
Variação Tumoral & $+5,2 \pm 4,6 \mathrm{~mm}$ & $-2,85 \pm 2,3 \mathrm{~mm}^{*}$ & $-7,51 \pm 2,6 \mathrm{~mm}^{*}$ & $-2,38 \pm 2,1 \mathrm{~mm}^{*}$ \\
Celularidade da & $1.1 \pm 0,55 \times 10^{7} / \mathrm{mL}$ & $0,95 \pm 0,09 \times 10^{7} / \mathrm{mL}$ & $0,94 \pm 0,09 \times 10^{7} / \mathrm{mL}$ & $1 \pm 0,11 \times 10^{7} / \mathrm{mL}$ \\
Medula Óssea & & & & \\
& & & &
\end{tabular}

Dados representados por média \pm desvio-padrão

${ }^{\mathrm{a}} N=7$

$R H=$ resíduo hexânico $\quad R H-C=$ resíduo hexânico associado a ciclofosfamida

${ }^{*} p<0,05$ ANOVA pós teste de Tukey

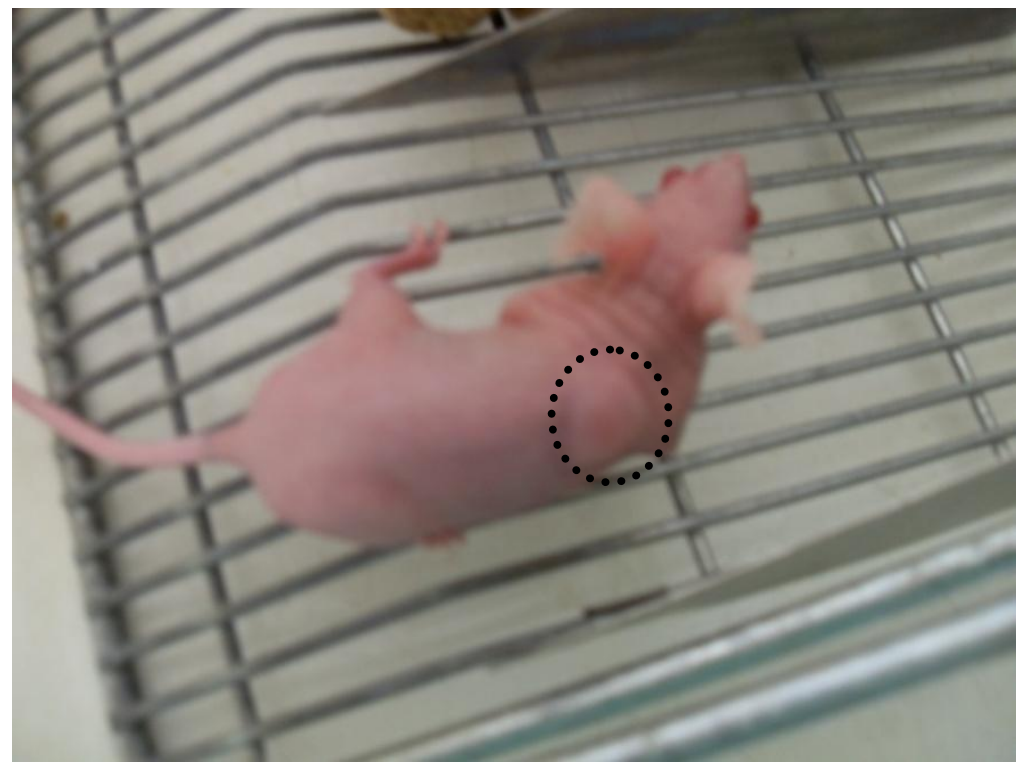

Figura 5- $\quad$ Fotografia que mostra um camundongo nude portador de linfoma A20 após 12 dias de inoculação das células tumorais. Diâmetro tumoral de cerca de $10 \mathrm{~mm}$ no início do tratamento (círculo tracejado) 


\section{Variação do Diâmetro Tumoral}

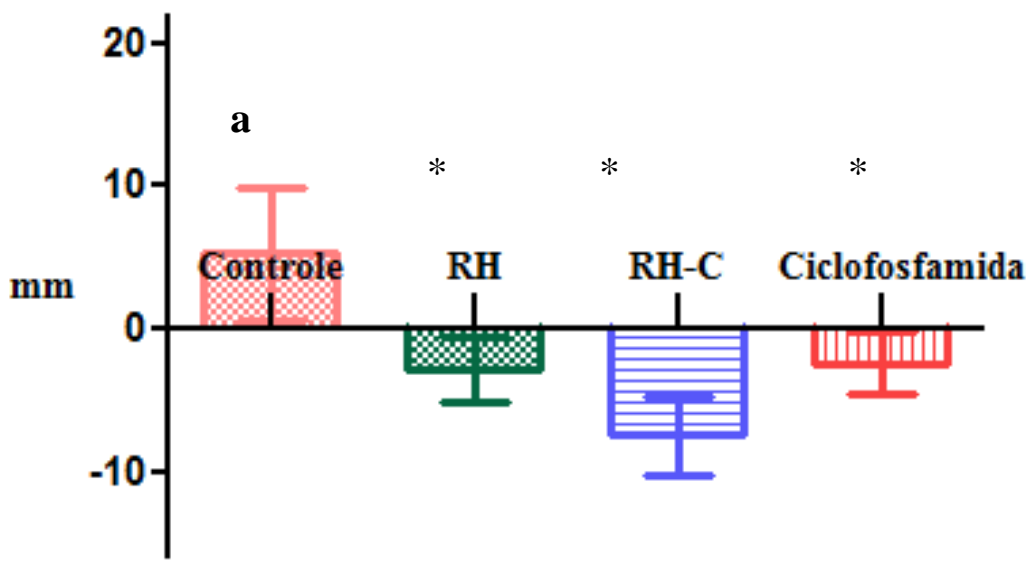

Figura 6- Variação do diâmetro tumoral medido no início e final do tratamento dos camundongos tratados com resíduo hexânico $(\mathrm{RH})$ de $B$. coridifolia, na dose de $0,5 \mathrm{~g} / \mathrm{kg}, \mathrm{RH}$ associado à ciclofosfamida ou apenas ciclofosfamida. Como grupo controle: água+Tween20, por via oral, através de gavage, e uma aplicação de água destilada intraperitonealmente, após sete dias de tratamento.

${ }^{*} p=0,0001$ ANOVA pós-teste Tukey

a.: Grupo controle $=4$ dias de tratamento 


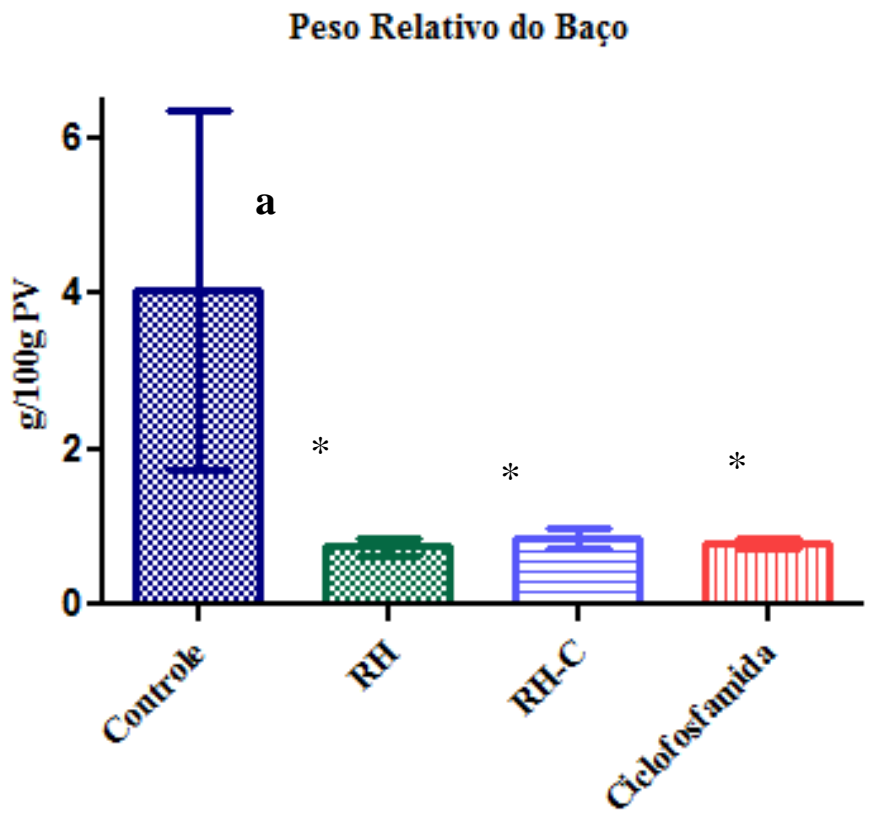

Figura 7- Peso relativo do baço dos camundongos tratados com resíduo hexânico $(\mathrm{RH})$ de $B$. coridifolia, na dose de $0,5 \mathrm{~g} / \mathrm{kg}, \mathrm{RH}$ associado à ciclofosfamida ou apenas ciclofosfamida. Como grupo controle: água+Tween20, por via oral, através de gavage, e uma aplicação de água destilada intraperitonealmente, após sete dias de tratamento.

${ }^{*} p=0,0001$ ANOVA pós-teste Tukey

a.: Grupo controle $=4$ dias de tratamento 
Tabela 16- Bioquímicos dos camundongos nude SPF, sadios do biotério do Departamento de Patologia da Faculdade de Medicina Veterinária e Zootecnia - USP e dos animais dos grupos tratados com resíduo hexânico $(\mathrm{RH})$, resíduo hexânico associado à ciclofosfamida $(\mathrm{RH}-\mathrm{C})$, ciclofosfamida $(\mathrm{C})$ e grupo controle

\begin{tabular}{cccccc}
\hline Itens Avaliados & Controle $^{\mathrm{a}}$ & $\mathrm{RH}^{\mathrm{a}}$ & $\mathrm{RH}-\mathrm{C}^{\mathrm{a}}$ & Ciclofosfamida $^{\mathrm{a}}$ & Nude $^{\mathrm{b}}$ \\
\hline ALT (U/L) & $292 \pm 196$ & $64 \pm 6^{*}$ & $39 \pm 2^{*}$ & $46 \pm 14^{*}$ & $30-90$ \\
GGT (U/L) & $3,58 \pm 0,78$ & $2,57 \pm 0,78^{*}$ & $2,14 \pm 0,37^{*}$ & $2,14 \pm 0,37^{*}$ & $1,2-3,0$ \\
Uréia (mg/dL) & $58 \pm 8,9$ & $73 \pm 13$ & $68 \pm 5,3$ & $62 \pm 11,7$ & $40-80$ \\
Creatinina & $0,4 \pm 0$ & $0,5 \pm 0$ & $0,4 \pm 0$ & $0,5 \pm 0$ & $0,4-0,8$ \\
(mg/dL) & & & & & \\
PT (g/dL) & $4,1 \pm 0,55$ & $4,4 \pm 0,46$ & $4,3 \pm 0,34$ & $4,2 \pm 0,29$ & $5,0-7,0$ \\
Albumina (g/dL) & $1,6 \pm 0,24$ & $1,8 \pm 0,14$ & $1,6 \pm 0,16$ & $1,7 \pm 0,15$ & $2,0-4,0$ \\
\hline
\end{tabular}

Dados representados por média \pm desvio-padrão ${ }^{a} N=7{ }^{b} N=4$

$R H=$ Resíduo Hexânico $\quad R H-C=$ Resíduo Hexânico associado a Ciclofosfamida

${ }^{*} p<0,05$ ANOVA pós teste de Tukey

a)

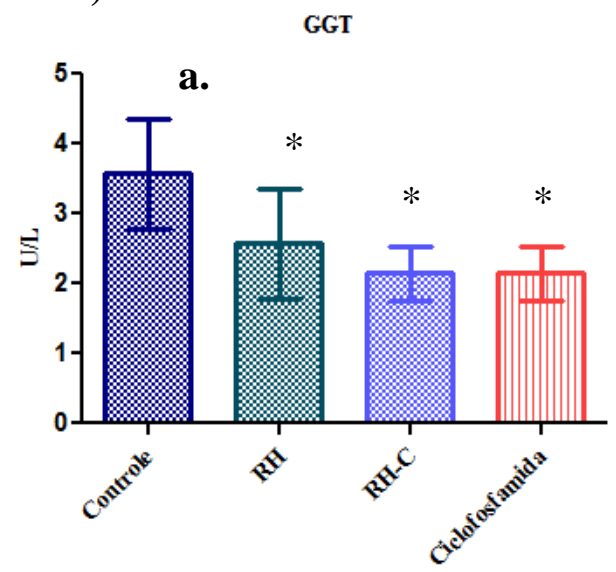

b)

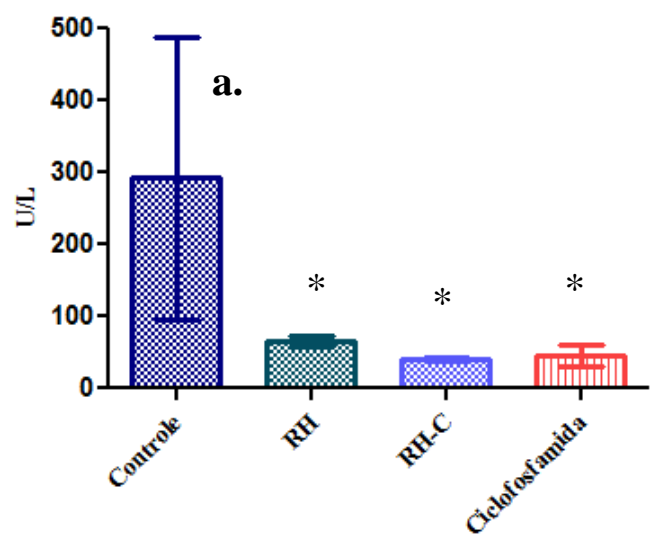

Figura 8 - Atividade das enzimas séricas GGT e ALT dos camundongos tratados com resíduo hexânico $(\mathrm{RH})$ de $B$. coridifolia, na dose de $0,5 \mathrm{~g} / \mathrm{kg}, \mathrm{RH}$ associado à ciclofosfamida ou apenas ciclofosfamida. Como grupo controle: água+Tween20, por via oral, através de gavage, e uma aplicação de água destilada intraperitonealmente, após sete dias de tratamento. a) GGT ${ }^{*} \mathrm{p}=0,0006$ ANOVA pós-teste Tukey b) ALT * $p=0,0001$ ANOVA pós-teste Tukey

a.: Grupo controle $=4$ dias de tratamento 


\begin{tabular}{|l|c|}
\hline Grupos & $\begin{array}{c}\text { Descrição histopatológica - FíGADO } \\
\text { Controle }\end{array}$ \\
\hline RH & $\begin{array}{l}\text { Fígado: Presença acentuada de infiltrado linfóide neoplásico } \\
\text { difuso em parênquima e em sinusóides e veias; }\end{array}$ \\
\hline RH-C & $\begin{array}{l}\text { Fígado: Presença discreta a moderada de megacariócitos e } \\
\text { polimorfonucleares. Apenas um animal apresentou presença } \\
\text { de infiltrado linfóide multifocal e em sinusóides e veias; }\end{array}$ \\
\hline Ciclofosfamida & $>\begin{array}{l}\text { Fígado: Discreta presença de infiltrado polimorfonuclear, } \\
\text { moderada presença de infiltrado megacariocítico; }\end{array}$ \\
\hline
\end{tabular}

Quadro 1- Descrição histopatológica de tecido hepático de camundongos do grupo controle e dos grupos tratados com $0,5 \mathrm{~g} / \mathrm{Kg}$ de resíduo hexânico $(\mathrm{RH})$, resíduo hexânico+ciclofosfamida- dose única $200 \mathrm{mg} / \mathrm{Kg}(\mathrm{RH}-\mathrm{C})$ e ciclofosfamida- dose única $200 \mathrm{mg} / \mathrm{Kg}(\mathrm{C})$ 


\begin{tabular}{|c|c|}
\hline Grupos & Descrição histopatológica - BAÇO \\
\hline Controle & $\begin{array}{l}\text { Baço: Perda da arquitetura por infiltrado de linfócitos } \\
\text { neoplásicos grandes e médios; figuras de mitose de 3-5 por } \\
\text { campo; }\end{array}$ \\
\hline $\mathbf{R H}$ & $\begin{array}{l}\text { Baço: Arquitetura levemente alterada com polpa branca } \\
\text { aumentada por linfócitos médios, moderada presença de } \\
\text { megacariócitos, presença discreta de polimorfonucleares em } \\
\text { polpa vermelha; }\end{array}$ \\
\hline RH-C & $\begin{array}{l}\text { Baço: Arquitetura preservada, moderada presença de } \\
\text { megacariócitos, discreta presença de polimorfonucleares em } \\
\text { polpa vermelha; }\end{array}$ \\
\hline Ciclofosfamida & $\begin{array}{l}\text { Baço: Maioria dos animais apresentou órgão com arquitetura } \\
\text { relativamente preservada, com folículos aumentados, } \\
\text { predominando linfócitos médios e grandes. Megacariócitos } \\
\text { também estavam presentes em moderada quantidade. Um } \\
\text { animal apresentou perda da arquitetura do órgão por } \\
\text { proliferação linfóide neoplásica; }\end{array}$ \\
\hline
\end{tabular}

Quadro 2 - Descrição histopatológica de tecido esplênico de camundongos do grupo controle e dos grupos tratados com $0,5 \mathrm{~g} / \mathrm{Kg}$ de resíduo hexânico $(\mathrm{RH})$, resíduo hexânico+ciclofosfamida- dose única $200 \mathrm{mg} / \mathrm{Kg}(\mathrm{RH}-\mathrm{C})$ e ciclofosfamida- dose única $200 \mathrm{mg} / \mathrm{Kg}(\mathrm{C})$

\begin{tabular}{|l|l|l|}
\hline Grupos & $\begin{array}{c}\text { Descrição histopatológica - PULMÃO } \\
\text { Controle }\end{array}$ & \multicolumn{1}{|c|}{ Pulmão: Presença discreta de infiltrado linfóide neoplásico } \\
& intersticial difuso e no interior de capilares; \\
\hline RH & $>$ Pulmão: Sem alterações; & \\
\hline RH-C & $>$ Pulmão: Alguns animais com discreta presença de \\
& polimorfonucleares; & \\
\hline Ciclofosfamida & $>$ Pulmão: Sem alterações; \\
\hline
\end{tabular}

Quadro 3 - Descrição histopatológica de tecido pulmonar de camundongos do grupo controle e dos grupos tratados com $0,5 \mathrm{~g} / \mathrm{Kg}$ de resíduo hexânico $(\mathrm{RH})$, resíduo hexânico+ciclofosfamida- dose única $200 \mathrm{mg} / \mathrm{Kg}(\mathrm{RH}-\mathrm{C})$ e ciclofosfamida- dose única $200 \mathrm{mg} / \mathrm{Kg}(\mathrm{C})$ 


\begin{tabular}{|l|r|}
\hline Grupos & Descrição histopatológica - RINS \\
\hline Controle & $>$ Rins: Presença discreta de infiltrado linfóide subcapsular; \\
\hline RH & $>$ Rins: Sem alterações; \\
\hline RH-C & $>$ Rins: Sem alterações; \\
\hline Ciclofosfamida & $>$ Rins: Sem alterações; \\
\end{tabular}

Quadro 4- Descrição histopatológica de tecido renal de camundongos do grupo controle e dos grupos tratados com $0,5 \mathrm{~g} / \mathrm{Kg}$ de resíduo hexânico $(\mathrm{RH})$, resíduo hexânico+ciclofosfamida- dose única $200 \mathrm{mg} / \mathrm{Kg}(\mathrm{RH}-\mathrm{C})$ e ciclofosfamida- dose única $200 \mathrm{mg} / \mathrm{Kg}(\mathrm{C})$

\begin{tabular}{|l|r|}
\hline Grupos & Descrição histopatológica - INTESTINO \\
\hline Controle & $>$ Intestino: Sem alterações; \\
\hline RH & $>$ Intestino: Sem alterações; \\
\hline RH-C & $>$ Intestino: Sem alterações; \\
\hline Ciclofosfamida & $>$ Intestino: Sem alterações; \\
\hline
\end{tabular}
grupos tratados com $0,5 \mathrm{~g} / \mathrm{Kg}$ de resíduo hexânico $(\mathrm{RH})$, resíduo hexânico+ciclofosfamida- dose única $200 \mathrm{mg} / \mathrm{Kg}(\mathrm{RH}-\mathrm{C})$ e ciclofosfamida- dose única $200 \mathrm{mg} / \mathrm{Kg}(\mathrm{C})$ 


\begin{tabular}{|c|c|}
\hline Grupos & Descrição histopatológica - LINFONODOS \\
\hline Controle & $\begin{array}{l}\text { Linfonodos (mandibular e axilar): Tecido linfóide neoplásico } \\
\text { com presença de hemorragia e necrose figuras de mitose 2-3 } \\
\text { por campo; } \\
\text { Presença de tecido neoplásico (linfócitos médios a grandes) } \\
\text { associado à pele e tecido adiposo; }\end{array}$ \\
\hline $\mathbf{R H}$ & $\begin{array}{l}\text { Linfonodos (mandibular e axilar): Dois animais apresentaram } \\
\text { aumento destes linfonodos, cujo tecido linfóide neoplásico } \\
\text { demonstrava presença de hemorragia e necrose, figuras de } \\
\text { mitose 2-3 por campo. Demais animais: não coletados devido } \\
\text { à ausência de alteração de volume (não palpáveis); }\end{array}$ \\
\hline RH-C & $\begin{array}{l}\text { Linfonodos (mandibular e axilar): Não coletados devido à } \\
\text { ausência de alteração de volume (não palpáveis); }\end{array}$ \\
\hline Ciclofosfamida & $\begin{array}{l}\text { Linfonodos: (mandibular e axilar): Não coletados devido à } \\
\text { ausência de alteração de volume (não palpáveis); }\end{array}$ \\
\hline
\end{tabular}

Quadro 6- Descrição histopatológica de linfonodos axilar e mandibular de camundongos do grupo controle e dos grupos tratados com $0,5 \mathrm{~g} / \mathrm{Kg}$ de resíduo hexânico $(\mathrm{RH})$, resíduo hexânico+ciclofosfamida- dose única $200 \mathrm{mg} / \mathrm{Kg}(\mathrm{RH}-\mathrm{C})$ e ciclofosfamidadose única $200 \mathrm{mg} / \mathrm{Kg}(\mathrm{C})$ 


\begin{tabular}{|l|c|}
\hline Grupos & Descrição histopatológica - TUMOR \\
\hline Controle & $\begin{array}{l}\text { TUMOR: Tecido neoplásico composto de linfócitos pequenos a } \\
\text { médios, presença de moderada hemorragia e necrose. Figuras } \\
\text { de mitose 3-5 por campo. }\end{array}$ \\
\hline RH & $\begin{array}{l}\text { TUMOR: Tecido neoplásico composto de linfócitos pequenos a } \\
\text { médios, presença de moderada hemorragia e de histiócitos e } \\
\text { plasmócitos na periferia, moderada presença de mastócitos na } \\
\text { derme superior. Figuras de mitose 1-2 por campo. }\end{array}$ \\
\hline RH-C & $\begin{array}{l}\text { TUMOR: Tecido neoplásico composto de linfócitos pequenos a } \\
\text { médios, presença de discreta hemorragia e de histiócitos e } \\
\text { plasmócitos na periferia, moderada presença de mastócitos na } \\
\text { derme superior. Infiltrado inflamatório misto, composto de } \\
\text { macrófagos, linfócitos e polimorfonucleares. Menor densidade } \\
\text { celular. Presença de necrose. Figuras de mitose 1-2 por } \\
\text { campo. }\end{array}$ \\
\hline Ciclofosfamida & $>\begin{array}{l}\text { TUMOR: Histologicamente semelhante ao grupo RH, com } \\
\text { presença de células bizarras e figuras de mitose aberrantes. }\end{array}$ \\
\hline
\end{tabular}

Quadro 7- Descrição histopatológica de tecido neoplásico primário inoculado subcutaneamente entre as escápulas de camundongos do grupo controle e dos grupos tratados com 0,5g/Kg resíduo hexânico $(\mathrm{RH})$, resíduo hexânico+ciclofosfamida- dose única $200 \mathrm{mg} / \mathrm{Kg}(\mathrm{RH}-\mathrm{C})$ e ciclofosfamida- dose única $200 \mathrm{mg} / \mathrm{Kg}$ (C) 


\subsection{EXPERIMENTO 6 - PADRONIZAÇÃO DA TÉCNICA DE MTT PARA AVALIAÇÃO DAS CÉlULAS TUMORAIS A20, ESPLENÓCITOS E TIMÓCITOS}

As células tumorais A20, timócitos e esplenócitos foram cultivadas em quadruplicatas durante 24 e 48 horas para o linfoma A20 e durante 24 horas para timócitos e esplenócitos. As células foram cultivadas em placas de 96 wells, nas concentrações de $1 \times 10^{7}$ cél $/ \mathrm{ml} 1 \times 10^{6}$ cél $/ \mathrm{ml} ; 1 \times 10^{5}$ cél $/ \mathrm{ml} ; 1 \times 10^{4}$ cél $/ \mathrm{ml}$ e $1 \times 10^{3}$ cél $/ \mathrm{ml} \mathrm{em}$ meio RPMI-1640 enriquecido com $10 \%$ de soro fetal bovino (SFB) estéril. Após o período de incubação utilizou-se a técnica de MTT para avaliação da proliferação celular. Os procedimentos utilizados estão detalhadamente descritos no item 3.4.12.

\subsubsection{Resultados Experimento 06}

\section{Células A20}

Para padronização da concentração de células tumorais A20 a serem cultivadas in vitro em placas 96 wells, utilizou-se a técnica de quantificação do índice de proliferação celular através do ensaio do MTT [brometo de 3-(4,5-dimetiltiazol-2-il)-5difeniltetrazólio]. Assim, de acordo com cada absorbância obtida em relação às concentrações de células cultivadas, pôde-se observar que para ambos os intervalos de 24 e 48 horas de cultivo, a concentração de $1 \times 10^{6}$ céls $/ \mathrm{mL}$ mostrou-se ideal para plaqueamento das células em placas de 96wells para futuros experimentos. De acordo com o protocolo utilizado, a concentração ideal de células deve obter uma absorbância que varia entre $0,75-1,25 \mathrm{~nm}$, entretanto, nesta absorbância, a concentração de células $/ \mathrm{mL}$ estaria muito superior a concentração de $1 \times 10^{7}$ cél/mL (Figuras 9 e 10). As células linfóides A20 possuem padrão de crescimento rápido, dobrando em número a cada 18horas, tendo seu crescimento prejudicado quando entram em confluência, entrando em apoptose. Dessa forma, optou-se pela concentração entre $8 \times 10^{5} \mathrm{e}$ 
$1 \times 10^{6}$ céls $/ \mathrm{mL}$, cuja absorbância é de aproximadamente $0,21 \mathrm{~nm}$, pois nesta absorbância a quantidade de células não seria um fator prejudicial ao crescimento das mesmas, já que as células A20 não atingem confluência nesta concentração (ATCC Cell Biology).

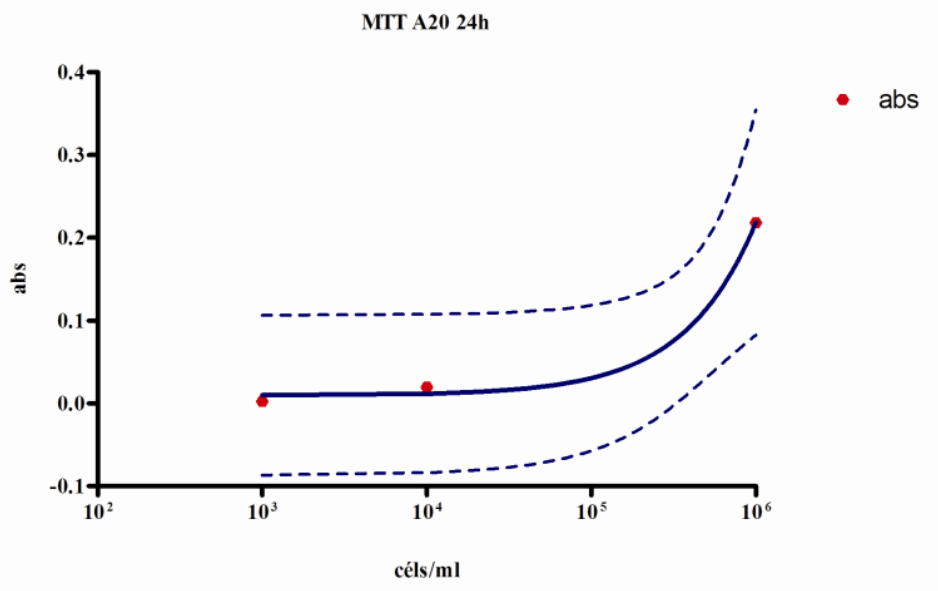

Figura 9 - Células tumorais A20 in vitro. Técnica de MTT 24h

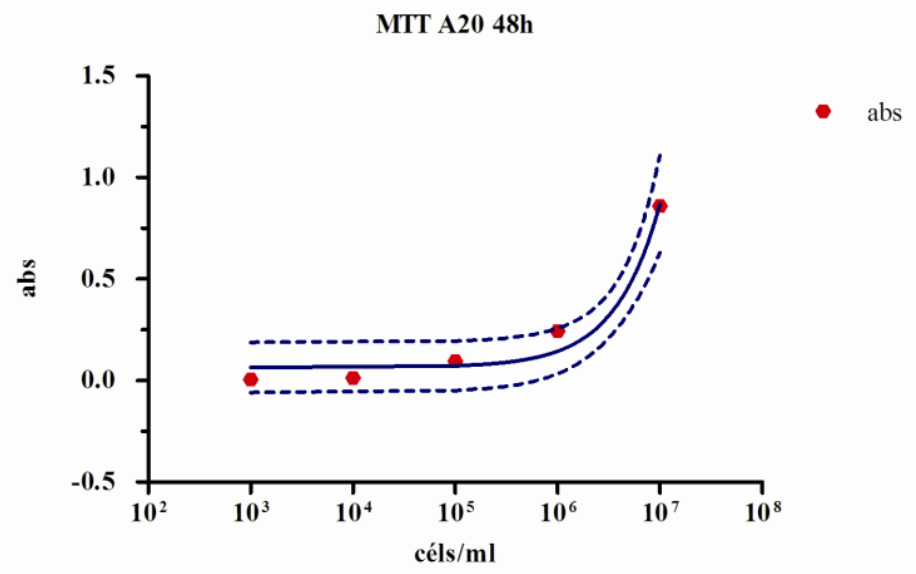

Figura 10 - Células tumorais A20 in vitro. Técnica de MTT 48h 


\section{Esplenócitos e Timócitos}

As células provenientes do baço (esplenócitos) apresentaram valores de absorbância de 0,07 quando cultivadas na concentração de $8 \times 10^{5} \mathrm{cel} / \mathrm{ml}$ e absorbância de 0,2 quando cultivadas na concentração de $1 \times 10^{6} \mathrm{cel} / \mathrm{ml}$ (Figura 11-A). Por outro lado, estes valores obtidos dos timócitos foram de 0, 007 quando cultivados na concentração de $8 \times 10^{5} \mathrm{cel} / \mathrm{ml}$ e absorbância de 0,056 quando cultivados na concentração de $1 \times 10^{6}$ $\mathrm{cel} / \mathrm{ml}$ (Figura 11-B).
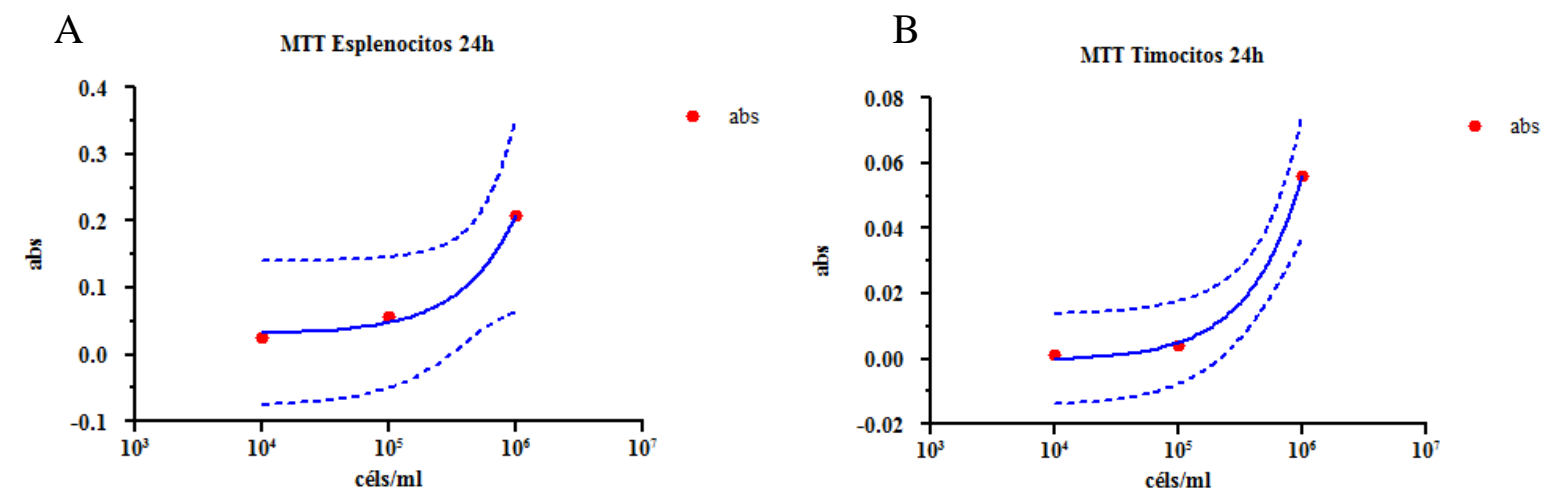

Figura 11 - A. MTT de esplenócitos após 24 horas de cultivo. B. MTT de timócitos após 24 horas de cultivo

\subsection{EXPERIMENTO 07 TRATAMENTO DE CÉLULAS DE LINFOMA A20, ESPLENÓCITOS E TIMÓCITOS COM DIFERENTES DOSES DE EE2 E RH}

A viabilidade de células de linfócitos normais e tumorais e células de Ehrlich foi determinada pela técnica de MTT (3-[4,5-dimethylthiazol] - 2,5 - brometo de diphenyltetrazolium). Linfócitos normais foram obtidos a partir de três camundongos BALB/C utilizando-se amostras de baço (esplenócitos) e timo (timócitos). As células tumorais empregadas foram obtidas da linhagem linfoma A20. Culturas em quadruplicatas para cada linhagem de células $\left(8 \times 10^{5}\right.$ células $\left./ \mathrm{ml}\right)$ foram realizadas da seguinte maneira: células não tratadas e tratadas com RH e EE2: $10 \mathrm{mg} / \mathrm{ml} 1 \mathrm{mg} / \mathrm{ml}$ 
$100 \mu \mathrm{g} / \mathrm{ml} 10 \mu \mathrm{g} / \mathrm{ml}$. As células foram incubadas durante $24 \mathrm{~h}$ em $37^{\circ} \mathrm{C}$ em atmosfera húmida, contendo $5 \%$ de $\mathrm{CO} 2$ até doseamento por MTT. Os procedimentos utilizados estão detalhadamente descritos no item 3.4.13.

\subsubsection{Resultados Experimento 07}

O tratamento com as doses de $10 \mathrm{mg} / \mathrm{ml}, 1 \mathrm{mg} / \mathrm{ml}, 100 \mu \mathrm{g} / \mathrm{ml}$ e $10 \mu \mathrm{g} / \mathrm{ml}$ do EE2 não demonstrou não promover efeito sob a proliferação das células A20, timócitos e esplenócitos. A pequena variação das absorbâncias resultantes após 0 tratamento por 24 horas (Figura 12) revela que o EE2 não inibe a proliferação destas células nestas concentrações ( $p>005)$. Em contrapartida, o tratamento com $\mathrm{RH}$ nas doses de $10 \mathrm{mg} / \mathrm{ml}$ e $1 \mathrm{mg} / \mathrm{ml}$ reduziu significantemente $(p<0,005)$ a proliferação celular do linfoma A20, sem alterar a proliferação dos timócitos e esplenócitos (Figura 13).

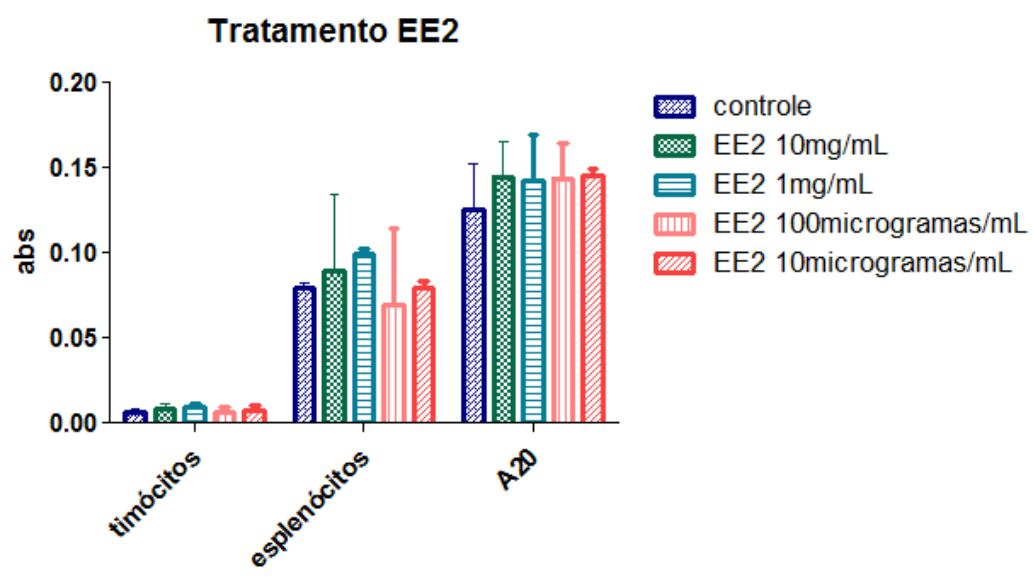

Figura 12 - Tratamento com diferentes doses de EE2 (Extrato Etanólico $2^{\mathrm{a}}$ partida). Estudo in vitro dos efeitos do EE2 nas concentrações de $10 \mathrm{mg} / \mathrm{ml}, 1 \mathrm{mg} / \mathrm{ml}, 100 \mu \mathrm{g} / \mathrm{ml} \mathrm{e}$ $10 \mu \mathrm{g} / \mathrm{ml}$, sob diferentes linhagens celulares. 


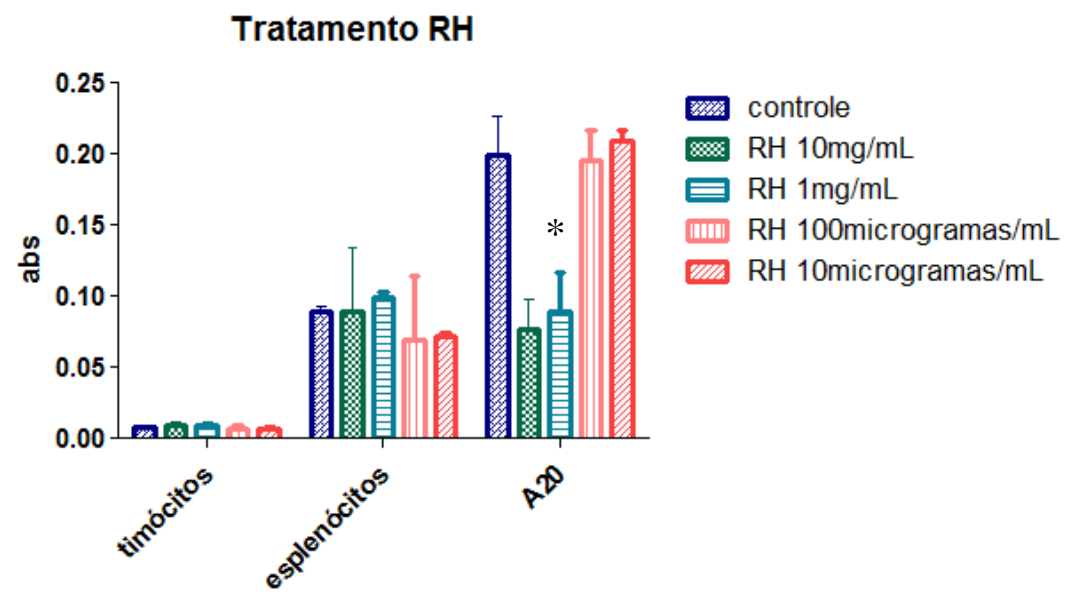

Figura 13 - Tratamento com diferentes doses de $\mathrm{RH}$ (resíduo hexânico). Estudo in vitro dos efeitos do RH nas concentrações de $10 \mathrm{mg} / \mathrm{ml}, 1 \mathrm{mg} / \mathrm{ml}, 100 \mu \mathrm{g} / \mathrm{ml}$ e $10 \mu \mathrm{g} / \mathrm{ml}$, sob diferentes linhagens celulares. "Diminuição significante da viabilidade celular das células tumorais do linfoma A20 nas doses de $10 \mathrm{mg} / \mathrm{ml}$ e de $1 \mathrm{mg} / \mathrm{ml}{ }^{*} \mathrm{p}=0,0005$ ANOVA pós-teste Tukey. Os esplenócitos e timócitos cultivados com a mesma concentração do $\mathrm{RH}$ não sofreram perda significante da viabilidade celular

\subsection{EXPERIMENTO 08 - TRATAMENTO DE CÉLULAS DE LINFOMA A20, TUMOR DE EHRLICH, ESPLENÓCITOS E TIMÓCITOS COM RH 1mg/ml}

A viabilidade de células de linfócitos normais e tumorais e células de Ehrlich foi determinada pela técnica de MTT (3-[4,5-dimethylthiazol] - 2,5 - brometo de diphenyltetrazolium). Linfócitos normais foram obtidos a partir de três camundongos BALB/C e Swiss utilizando-se amostras de baço (esplenócitos) e timo (timócitos). As células tumorais empregadas foram das linhagens: linfoma A20 e carcinoma de Ehrlich. Culturas em quadruplicatas para cada linhagem de células $\left(8 \times 10^{5}\right.$ células $\left./ \mathrm{ml}\right)$ foram realizadas da seguinte maneira: células não tratadas e tratadas com $\mathrm{RH} 1 \mathrm{mg} / \mathrm{ml}$; com incubação de $24 \mathrm{~h}$ em $37^{\circ} \mathrm{C}$ em atmosfera húmida, contendo $5 \%$ de $\mathrm{CO} 2$ até 
doseamento por MTT. Os procedimentos utilizados estão detalhadamente descritos no item 3.4.14.

\subsubsection{Resultados Experimento 08}

De acordo com os valores de absorbância obtidos em todas as culturas, observou-se que os esplenócitos e timócitos cultivados com o $\mathrm{RH} 1 \mathrm{mg} / \mathrm{ml}$ durante 24 horas, não apresentaram diminuição de viabilidade. Por outro lado, as células tumorais cultivadas: linfoma A20 e carcinoma de Ehrlich mostraram variação significante $(p<0$, 005) nos valores de absorbância das células tratadas em relação às células não tratadas com $\circ \mathrm{RH}$. As células tumorais tratadas com $\circ \mathrm{RH}$ obtiveram valores de absorbância menores que as células tumorais não tratadas, revelando, portanto, que o cultivo com o $\mathrm{RH}$ promoveu diminuição da viabilidade destas células em 24 horas (Figura 14).

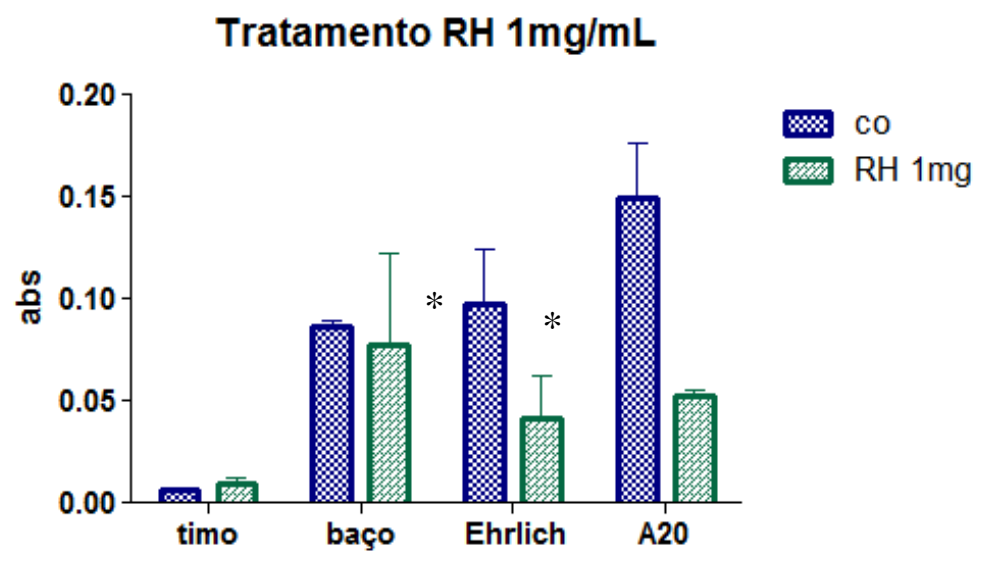

Figura 14 - Tratamento com RH 1mg/ml. Estudo in vitro dos efeitos do RH (resíduo hexânico) na concentração de $1 \mathrm{mg} / \mathrm{ml}$, sob diferentes linhagens celulares. "Diminuição significante da viabilidade celular das células tumorais do linfoma A20 e de carcinoma mamário de Ehrlich, cultivadas com RH $1 \mathrm{mg} / \mathrm{ml}$. Os esplenócitos e timócitos cultivados com a mesma concentração do $\mathrm{RH}$ não sofreram perda significante da viabilidade celular. $* p=0,0005$ ANOVA pós-teste Tukey 


\subsection{EXPERIMENTO 09 - IDENTIFICAÇÃO DOS TRICOTECENOS MACROCÍCLICOS NO EXTRATO ETANÓLICO DE B. CORIDIFOLIA}

A preparação dos resíduos foi realizada conforme item 2.4.1.2 e está esquematizada segundo fluxograma da figura 15.

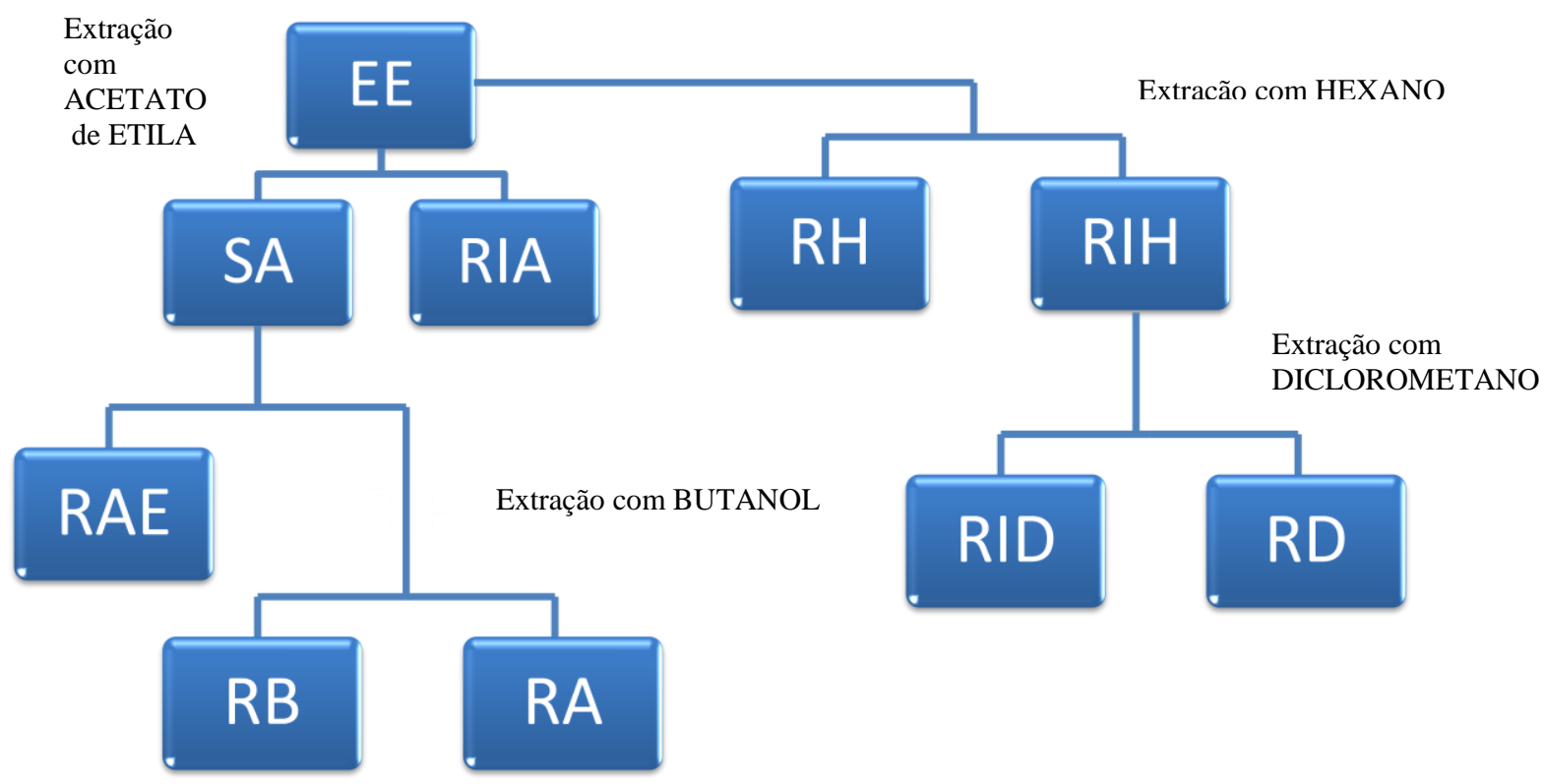

Figura 15 - Identificação dos tricotecenos macrocíclicos no extrato etanólico de $B$. coridifolia. Preparação dos resíduos. EE: Extrato Etanólico, SA: Solução Aquosa RIA: Resíduo Insolúvel em Água RAE: Resíduo Acetato de Etila, RB: Resíduo Butanólico, RA: Resíduo Aquoso, RH: Resíduo Hexânico, RIH: Resíduo Insolúvel em Hexano, RID: Resíduo Insolúvel em Diclorometano, RD: Resíduo Diclorometan 


\subsubsection{Resultados Experimento 09}

\section{Análise Cromatográfica}

Em relação à análise cromatográfica dos resíduos $\mathrm{RH}, \mathrm{RIA}$ e EE, a cromatografia em camada delgada revelou a presença de manchas observáveis em luz UV e manchas reveladas apenas em $\mathrm{H}_{2} \mathrm{SO}_{4} 10 \%$. As manchas reveladas no UV não foram características da presença de terpenos, já que nesta radiação são mais comumente observadas substâncias aromáticas. As manchas reveladas em $\mathrm{H}_{2} \mathrm{SO}_{4} 10 \%$ podem sugerir a presença de terpenos, de acordo com metodologia descrita por Wagner (1996). Os resíduos RH RIA e EE parecem possuir as mesmas substâncias, já que demonstraram o mesmo padrão de corrida na análise cromatográfica, sendo que a análise bidimensional do $\mathrm{EE}$ revelada em $\mathrm{H}_{2} \mathrm{SO}_{4} \quad 10 \%$ demonstrou a presença de algumas substâncias com características de terpenos. Os resíduos RD, RID, RAE e RB não demonstraram substâncias reveladas pelo $\mathrm{H}_{2} \mathrm{SO}_{4} 10 \%$. Os resultados das manchas reveladas no UV e no $\mathrm{H}_{2} \mathrm{SO}_{4} 10 \%$ estão apresentados nas figuras $17,18,19$ e 20 . A estrutura molecular dos tricotecenos macrocíclicos mais comumente encontrados na $B$. coridifolia são ilustrados na figura 16.

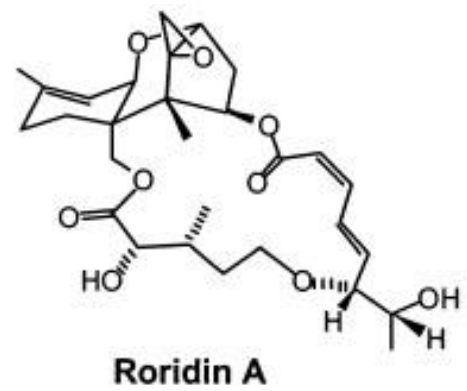

Roridin A

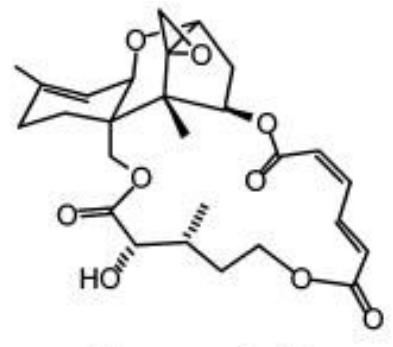

Verrucarin A

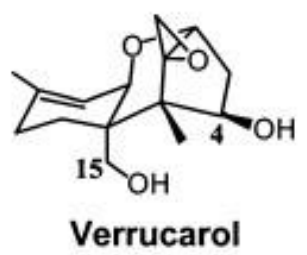

Verrucarol

Figura 16-. Tricotecenos macrocíclicos. Estrutura molecular dos principais tricotecenos macrocíclicos presentes em $B$. coridifolia 


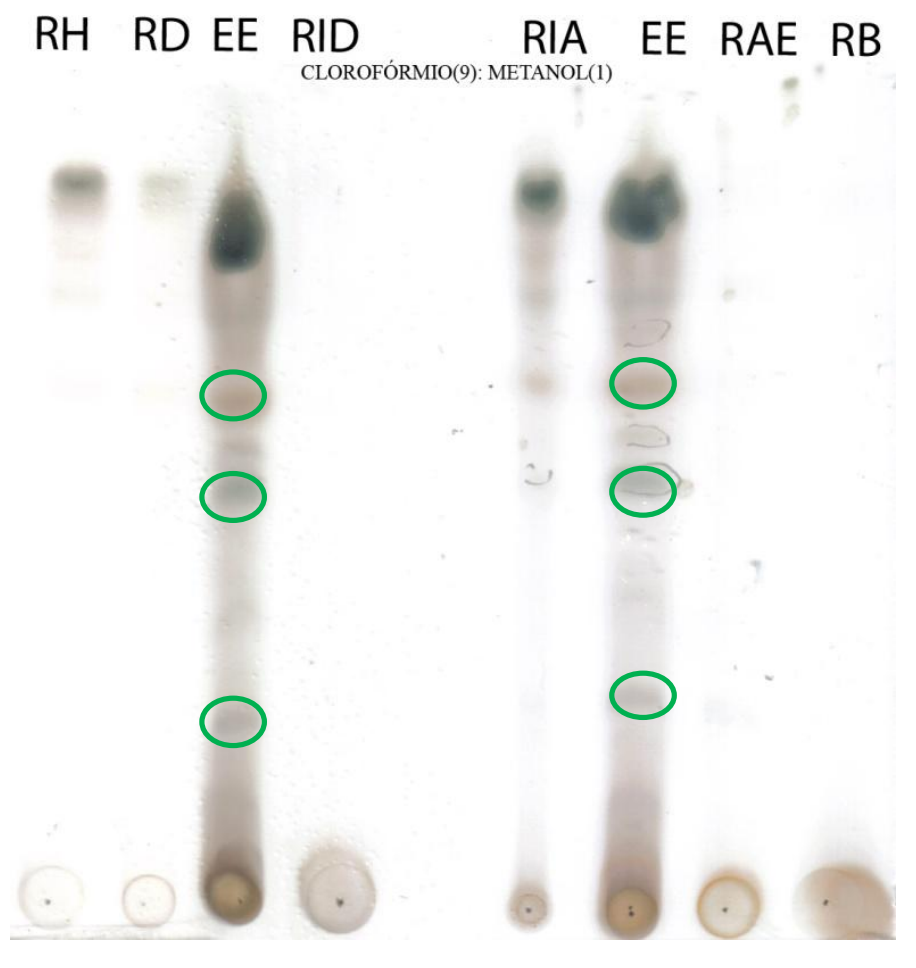

Fase móvel:clorofórmio (93) :acetona (7)

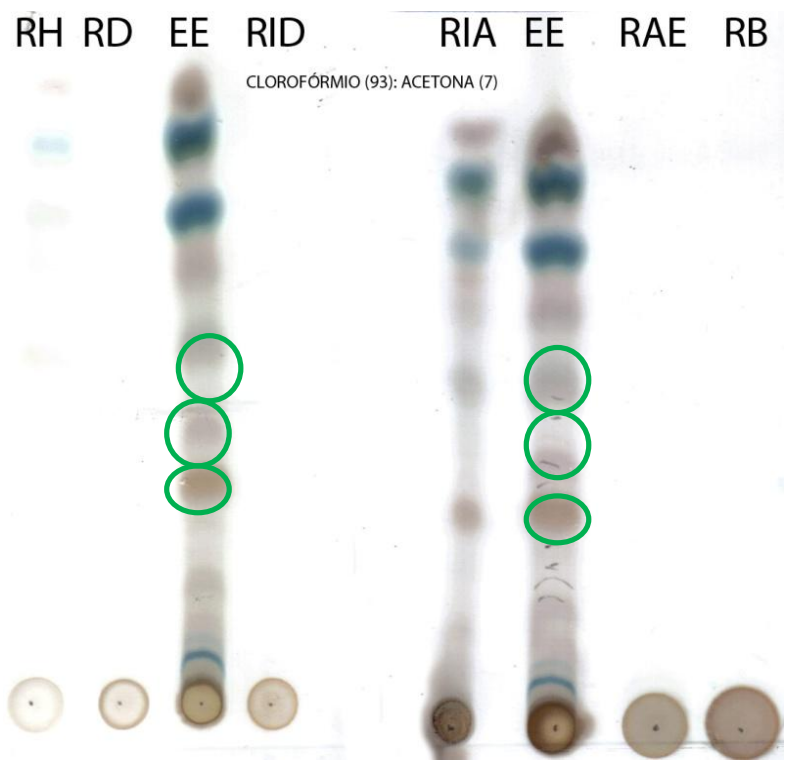

Fase móvel: clorofórmio (9): metanol (1)
Figura 17 - Cromatografia em camada delgada (TLC). A análise cromatográfica demonstrou que o extrato etanólico de $B$. coridifolia (EE), o resíduo insolúvel em água (RIA) e o resíduo hexânico $(\mathrm{RH})$ parecem possuir as mesmas substâncias. As manchas circuladas em verde não foram reveladas na luz UV, apenas em $\mathrm{H}_{2} \mathrm{SO}_{4} \quad 10 \%$, indicando prováveis presenças de terpenóides
Figura 18 - Cromatografia em camada delgada (TLC). A análise cromatográfica

demontsrou que o extrato etanólico de $B$. coridifolia (EE), o resíduo insolúvel em água (RIA) e o resíduo hexânico $(\mathrm{RH})$ parecem possuir as mesmas substâncias. As manchas circuladas em verde não foram reveladas na luz $\mathrm{UV}$, apenas em $\mathrm{H}_{2} \mathrm{SO}_{4}$ $10 \%$, indicando prováveis presenças de terpenóides 


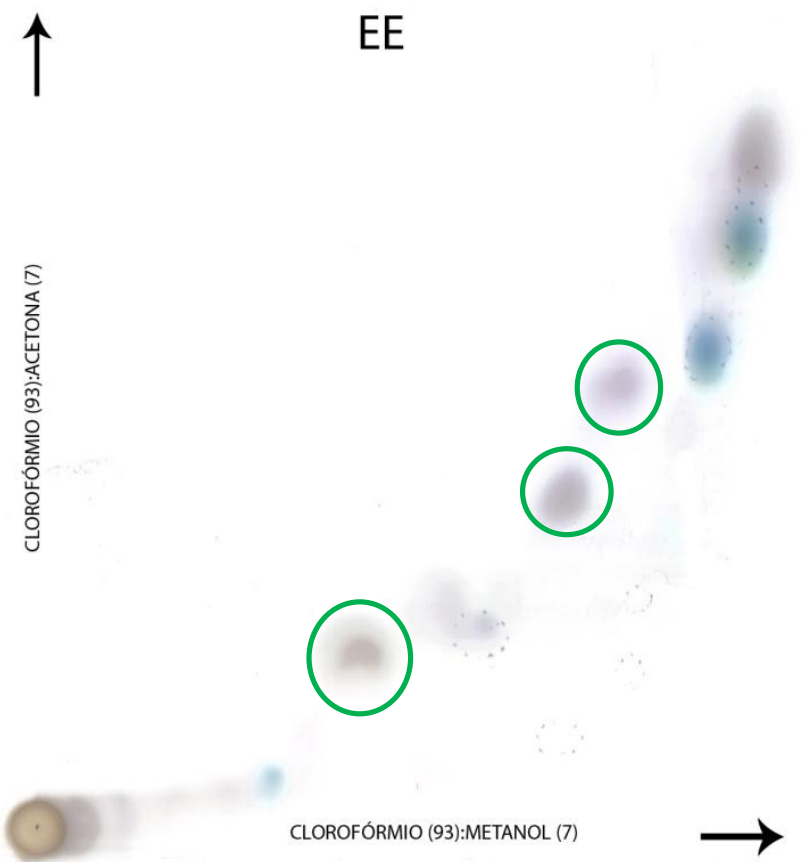

Figura 19 - Cromatografia de alta resolução (HPTLC). Análise cromatográfica bidimensional do EE de $B$ coridifolia. As manchas circuladas em verde não foram reveladas na luz UV, apenas em $\mathrm{H}_{2} \mathrm{SO}_{4} 10 \%$, indicando prováveis presenças de terpenóides 
EE1 EE2

clorofórmio (97) : acetona (7)
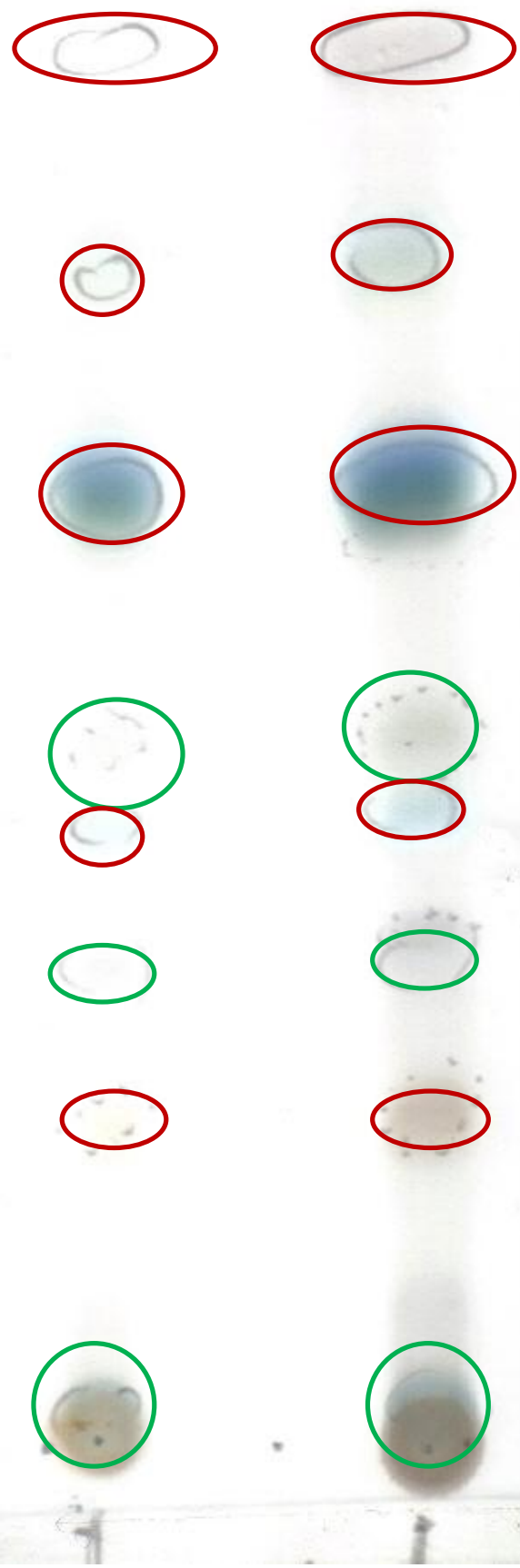

Fase móvel: clorofórmio (93): acetona (7)
Figura 20 - Cromatografia em camada delgada (TLC). A análise cromatográfica demonstrou que o EE de B. coridifolia de amostra coletada em fevereiro de 2008 (EE1), e o extrato etanólico de $B$. coridifolia de amostra coletada em setembro de 2008 (EE2) parecem possuir as mesmas substâncias. As manchas circuladas em verde não foram reveladas na luz UV, apenas em $\mathrm{H}_{2} \mathrm{SO}_{4} 10 \%$, indicando prováveis presenças de terpenóides. As manchas circuladas em vermelho foram reveladas na luz UV 


\subsection{EXPERIMENTO 10 - IDENTIFICAÇÃO DOS TRICOTECENOS MACROCÍCLICOS NO RESÍDUO HEXÂNICO DE B. CORIDIFOLIA}

Inicialmente, foram coletadas 40 frações $(B C 1)$ de seis $\mathrm{ml}$ cada, partindo-se de $300 \mathrm{mg}$ de $\mathrm{RH}$ obtido do EE1, pelo método de cromatografia em coluna, conforme detalhadamente descrito no item 2.4.1.3 e está esquematizado segundo fluxograma da figura 21-A. Posteriormente foi realizada uma segunda coluna de fracionamento partindo-se do EE2, onde foram coletadas 70 frações de três $\mathrm{ml}$ cada (BC2- figura 21B). Posteriormente as frações coletadas foram submetidas à análise por cromatografia em camada delgada (CCD) em corridas de oito $\mathrm{cm}$, juntamente com amostras padrão de Sitosterol e RH.

\subsubsection{Resultados Experimento 10}

As frações coletadas do $\mathrm{RH}$ na primeira coluna de fracionamento $(\mathrm{BC} 1)$ foram reunidas de acordo com a similaridade das manchas observadas na cromatografia em camada delgada (Figura 22-A, B) e seus respectivos Rf. O resultado é apresentado no fluxograma da figura 21-A. Foi realizada uma segunda cromatografia em coluna com a segunda partida de $B$. coridifolia, cujo EE obtido foi denominado EE2, resultando em um segundo $\mathrm{RH}$.

As frações coletadas do $\mathrm{RH}$ da segunda coluna de fracionamento (BC2) foram reunidas de acordo com a similaridade das manchas observadas na cromatografia em camada delgada (Figura 23-A, B) e seus respectivos $\mathrm{Rf}$, conforme ilustrado no fluxograma da figura 21-B. Uma amostra padrão Sitosterol (esteróide) foi utilizada na corrida da CCD para análise comparativa do valor Rf das outras amostras (Figura 23B). O valor Rf do sitosterol foi de $0,44 \mathrm{~cm}$, a observação de manchas com valores próximos deste Rf podem indicar a presença de terpenos. As frações reunidas em A, B, C, D e E foram enviadas para o laboratório de farmacologia do Departamento de Física e Química Orgânica da Faculdade de Ciências Farmacêuticas- Universidade de São Paulo. 


\section{A) Cromatografia em Coluna - BC1}

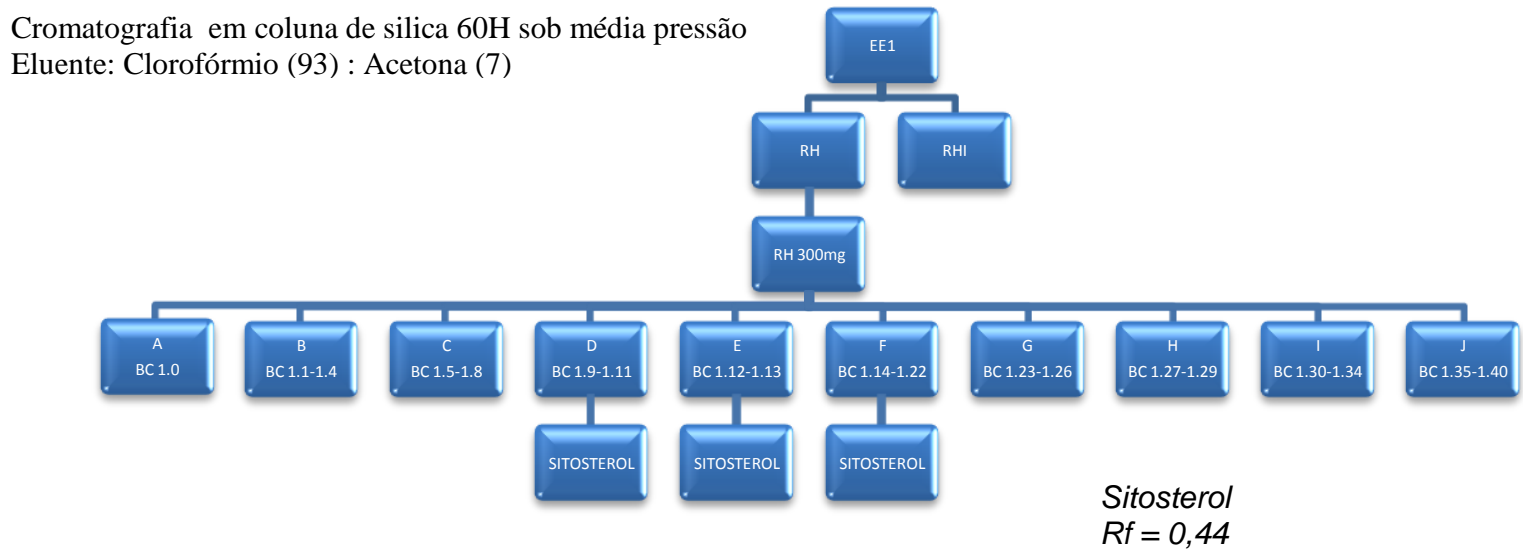

Volume $=6 \mathrm{ml}$

\section{B) Cromatografia em Coluna - BC2}
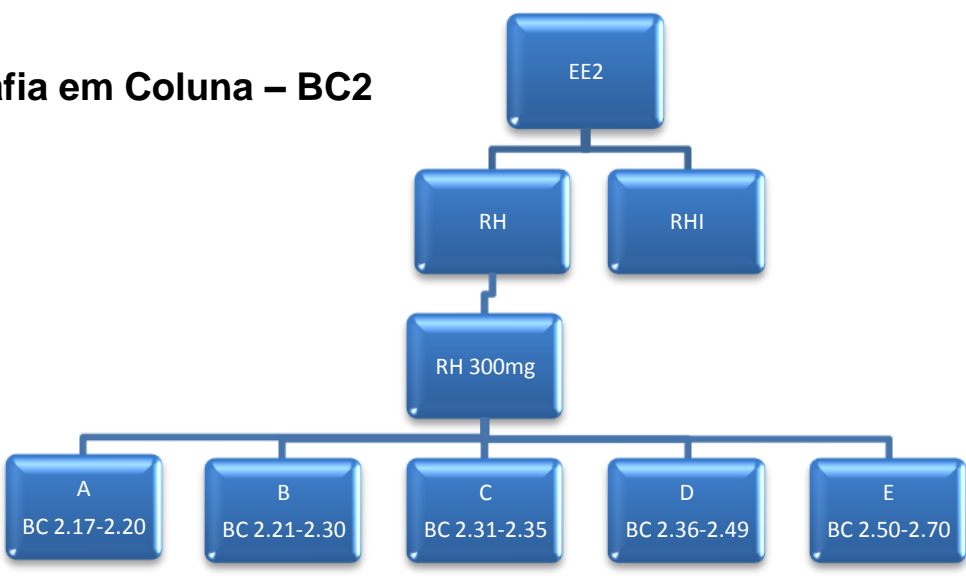

Figura 21-. Cromatografia em Coluna. A. Cromatografia em coluna partindo-se de amostra de extrato etanólico da primeira partida de $B$. coridifolia (EE1). As amostras foram reunidas em frações $A, B, C, D, E, F, G, H$, I e J(RH: resíduo hexânico $\mathrm{RHI}$ : resíduo insolúvel em hexano). B. Cromatografia em coluna partindo-se de amostra de extrato etanólico da segunda partida de B. coridifolia (EE2). As amostras foram reunidas em frações $A, B, C, D$ e $E(R H$ : resíduo hexânico $\mathrm{RHI}$ : resíduo insolúvel em hexano). 
A.

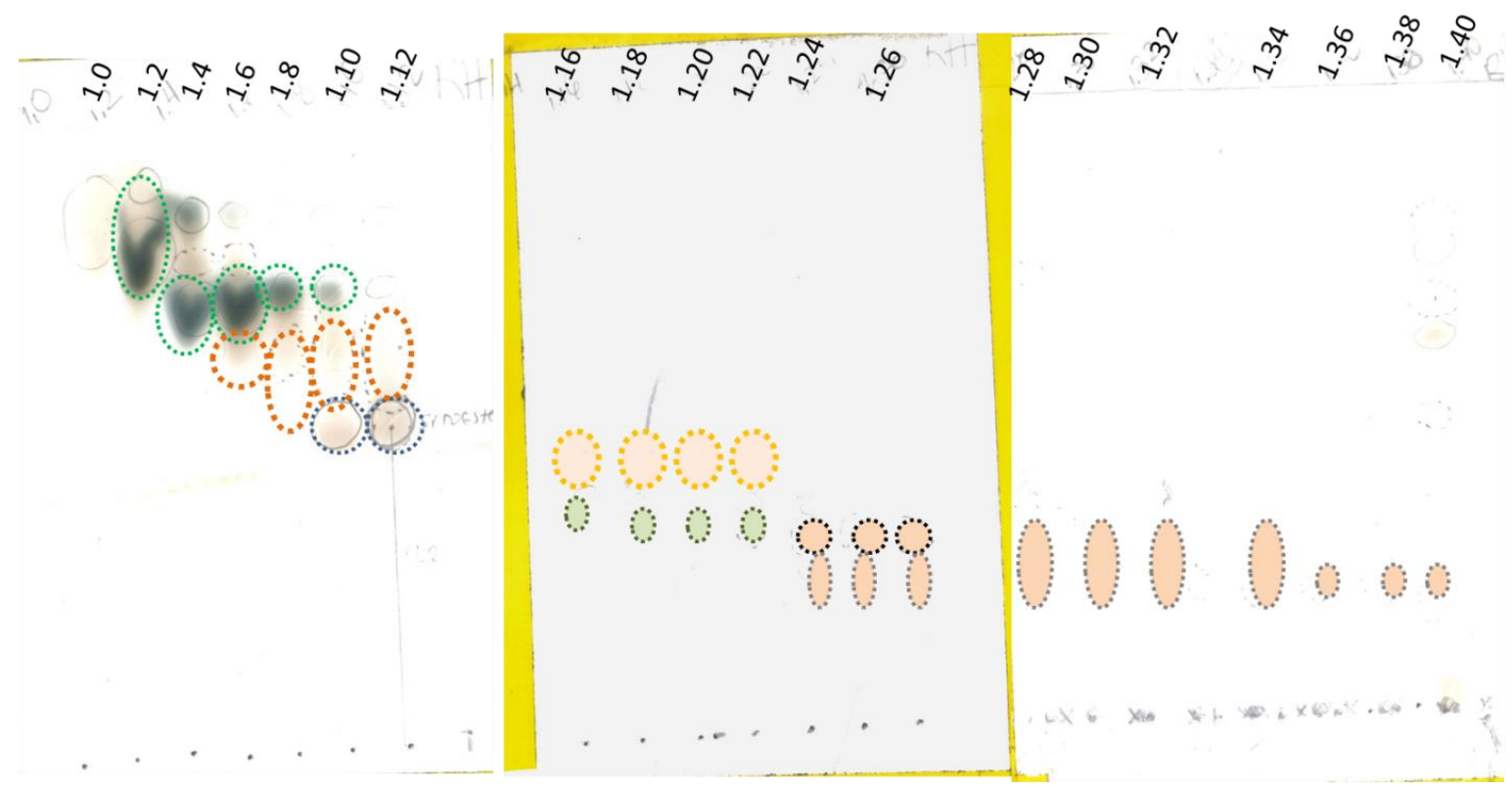

Figura 22. Cromatografia em camada delgada (TLC). A. Frações coletadas de 1.01.40 no volume de $6 \mathrm{~mL}$. As manchas demarcadas com círculos tracejados de mesma cor indicam similaridade B.

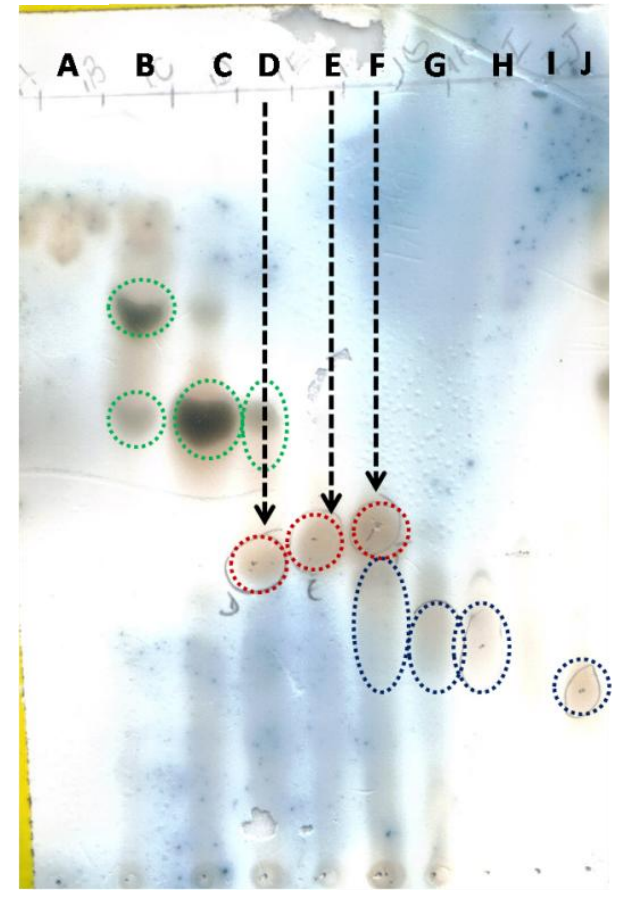
dos componentes de cada fração. Os círculos tracejados em azul indicam a presença de sitosterol. B. As frações similares foram reunidas em $A, B, C$, $D, E, F, G, H, I$ e J. A reunião das frações em $A, B$ e $C$ indicam a presença de clorofila. A reunião das frações $D$, E e $F$ possuem o mesmo valor de Rf do Sitosterol, indicando a provável presença de terpenos

Fase móvel: clorofórmio (93): acetona (7) 
A.

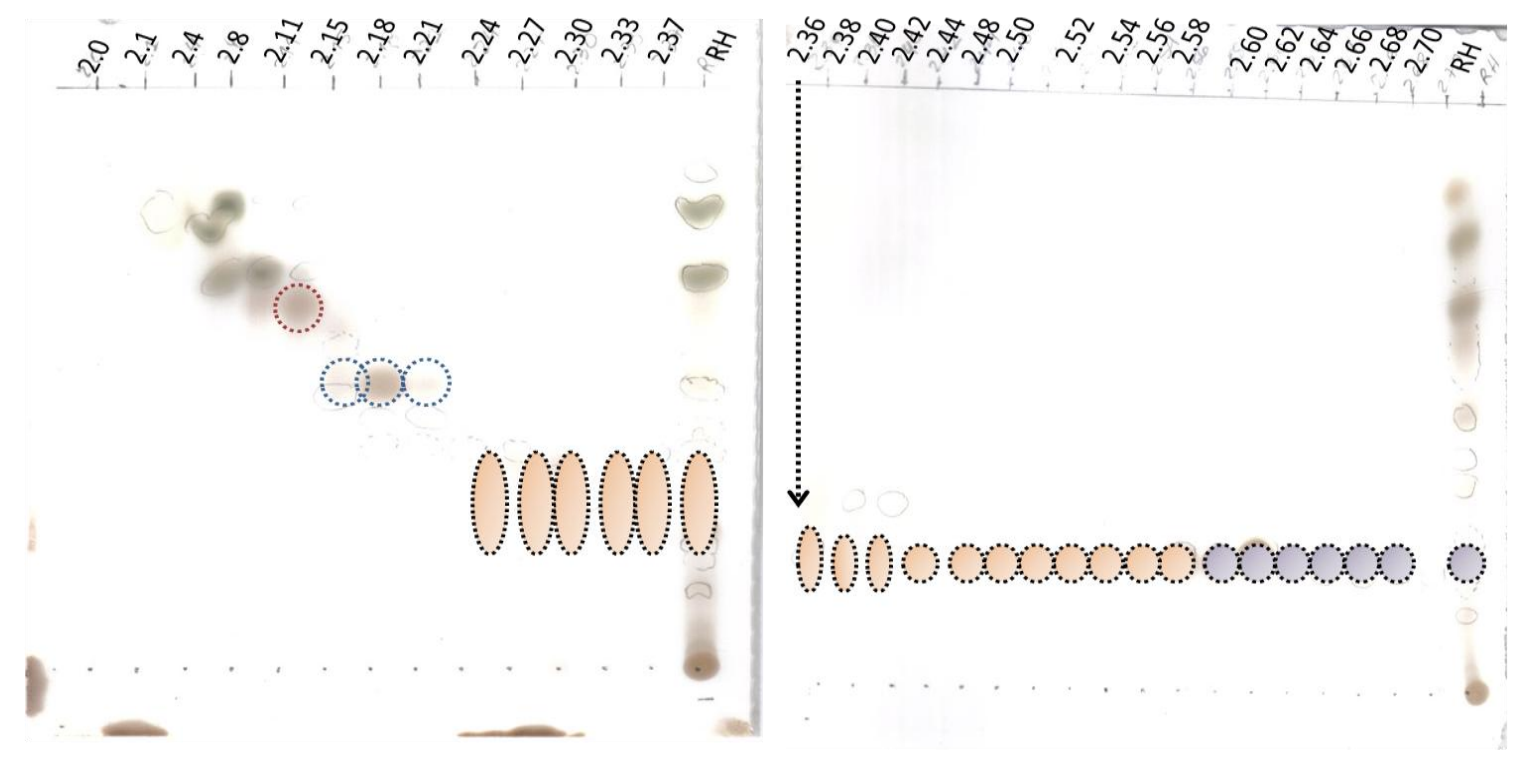

Figura 23. Cromatografia em camada delgada (TLC). A. Frações coletadas de 2.0-2.70 no volume de $3 \mathrm{~mL}$. As manchas demarcadas com círculos tracejados de mesma cor indicam similaridade dos componentes de cada fração. B. As frações similares foram reunidas em $A, B, C, D$ e $E$. As frações 2.17-2.20, reunidas em A possuem o mesmo valor de Rf do Sitosterol, indicando a provável presença de terpenos. As frações 2.21-2.30 foram reunidas em $\mathbf{B}, \quad 2.31-2.35$ reunidas em C, 2.36-2.49 reunidas em $D$ e $2.50-2.70$ reunidas em $\mathrm{E}$

B.

Fase móvel: clorofórmio (93): acetona (7) 
Discussão 


\section{DISCUSSÃO}

A B. coridifolia é uma planta tóxica de interesse veterinário que causa, em animais de produção, principalmente bovinos, morte por alterações gastrointestinais (TOKARNIA, 1955). Além disto, foi também descrito que esta toxicose promove, em bovinos, necrose em tecidos linfáticos, com exceção do timo. Posteriormente, um estudo pioneiro em animais de laboratório, conduzido por Varaschin (2002) mostrou que a administração de extrato bruto (EB) de $B$. coridifolia a camundongos causava efeito tóxico em linfócitos presentes nos tecidos linfóides secundários; esta mesma pesquisa mostrou, ainda, que o EB promoveu, nestes roedores, ao contrário do verificado na espécie bovina, alteração (necrose) do timo também.

Sabe-se que a $B$. coridifolia contém tricotecenos macrocíclicos, os quais, em pesquisas anteriores, mostraram possuir várias propriedades biológicas, tais como atividade antibiótica, antiviral, antileucêmica e ação imunomoduladora (KUPCHAN et al., 1977; JARVIS et al., 1988; HUGHES et al., 1989; ISAKA et al., 1999; GARCIA et al., 2002). Assim, foi objetivo principal deste trabalho verificar se extratos desta planta que conteriam os tricotecenos, poderiam ser empregados, em doses apropriadas, como instrumento terapêutico em doenças linfoproliferativas, como os linfomas, já que estes compostos teriam efeito tóxico sobre linfócitos. Desta feita, a presente pesquisa visa principalmente melhor conhecer o mecanismo de ação desta planta, focando os seus efeitos no sistema imune.

Neste estudo, inicialmente, procurou-se determinar se as doses da solução obtida da planta seriam eficazes para atingir os objetivos propostos, ou seja, foi necessário fazer a prospecção de doses da planta que não promovessem toxicidade nos animais, mas que pudessem mostrar possíveis efeitos sobre células linfóides malignas. Para tanto, obteve-se o mesmo tipo de solução (EB) que aquele empregado por Varaschin (2002), quando estudou a toxicidade da planta em bovinos e camundongos. Aqui, a EB foi administrada a camundongos da linhagem Swiss, em doses crescentes, verificando-se que $10 \mathrm{~g} / \mathrm{kg}$ da matéria seca (EB1 - folhas e talos) da B. coridifolia, coletada em fevereiro de 2008, promoveu a morte do animal de forma aguda, e este efeito ocorreu ao redor de 36 horas após a administração do extrato. 
É amplamente conhecido que há grande variação no conteúdo dos princípios ativos de uma planta devido a alguns fatores, tais como a época do ano na qual foram colhidas, as partes do vegetal ingerido (sementes, folhas, talos e raiz) entre outros (TOKARNIA, 2000). De fato, sabe-se que são necessários $2,0 \mathrm{~g} / \mathrm{kg}$ de folhas de $B$. coridifolia para causar a morte de bovinos quando esta é colhida em outubro/novembro (planta em brotação), enquanto que em março, quando este vegetal apresenta-se em floração e frutificação, verifica-se que apenas 0,25 a $0,5 \mathrm{~g} / \mathrm{kg}$ da planta já é capaz de promover tal efeito nesta mesma espécie animal (TOKARNIA, 2000).

Interessante que nesta pesquisa, o efeito esperado não foi o ocorrido; desta maneira, verificou-se que o extrato obtido de folhas secas coletadas em setembro (EB2) promoveu a morte dos camundongos a partir da dose de $8 \mathrm{~g} / \mathrm{Kg}$, enquanto que aquele extrato proveniente de material vegetal da planta, colhido de fevereiro a abril (EB1), ou seja, no período no qual deveria haver maior concentração de substâncias tóxicas na B.coridifolia, foi necessário $10 \mathrm{~g} / \mathrm{Kg}$ de planta. Pouco poderia ser especulado neste momento para tentar justificar tal resultado; entretanto, deve-se considerar que o material coletado em setembro compunha-se apenas por folhas, que é a parte mais tóxica da planta. Já as amostras de B.coridifolia, coletadas em fevereiro continham quase que exclusivamente talos, que sabidamente possui menor atividade tóxica (TOKARNIA; DOBEREINER; PEIXOTO, 2000). Portanto, é provável que esta diferença entre um e outro material vegetal deva ter influenciado no efeito tóxico da planta.

Devido ao fato de os tricotecenos pertencerem à classe das substâncias terpenóides, com características mais apolares, resolveu-se submeter ambas as partidas de plantas à extração com diferentes solventes, já que se supõe serem estes compostos aqueles responsáveis pelos efeitos no tecido linfóide. Por conseguinte, objetivando-se obter dos extratos brutos de $B$. Coridifolia a maior parte destes princípios ativos, realizou-se a extração por maceração em álcool, haja vista que este solvente possui capacidade de retirar diferentes substâncias com variações de polaridades. Assim, foram obtidos dois extratos: EE1 e EE2, correspondentes aos períodos de fevereiro e setembro de 2008, respectivamente; e, novamente foi realizado o ensaio biológico com camundongos Swiss e Balb/C, no qual foi possível verificar a diferença na toxicidade entre os dois extratos, evidenciando a variação no conteúdo de princípios 
ativos existentes nas partidas de plantas coletadas (dose tóxica EE1: 8g/Kg; EE2: $4 \mathrm{~g} / \mathrm{Kg}$ ).

Dando-se sequência aos ensaios biológicos com a partida que havia no laboratório no momento, ou seja, aquela coletada em fevereiro de 2008, procurou-se preparar concentrações de extrato bruto (EB1) que não excedessem 3,0 g/kg de planta por camundongo, sendo a menor dose administrada, durante os 21 dias, a de $0,1 \mathrm{~g} / \mathrm{kg}$ de planta. Contudo, em nenhum dos experimentos realizados, tais como análise hematológica, peso relativo de órgãos linfóides (timo e baço), celularidade de medula óssea e análise histológica de diferentes tecidos, foram observadas qualquer diferença estatística entre os valores obtidos dos animais dos grupos tratados com o extrato da planta e aqueles pertencentes ao grupo controle.

Logo, a partir destes dados obtidos, optou-se por administrar o EE1, em dose única (2,0 $\mathrm{g} / \mathrm{kg}$ da planta) por sete dias, utilizando-se como sujeito experimental camundongos da linhagem Balb/C, já que o tipo de linfoma a ser implantado (células tumorais A20) é padronizado para se desenvolver nesta linhagem (KIM et al., 1979). Importantes dados foram encontrados neste experimento; assim, verificou-se que a administração do EE1 promoveu uma série de alterações nos animais, sendo que aquelas que mais chamaram a atenção foram a expressiva diminuição no peso relativo de timo e a diminuição na porcentagem do número de linfócitos periféricos, quando da realização do diferencial de células brancas. Além disto, verificou-se também que, embora o tratamento com EE1 tenha produzido estas consistentes alterações, não foram observadas alterações no timo e baço dos animais, como necrose ou apoptose de linfócitos. Considerando-se que, dos linfócitos presentes na circulação sanguínea, $70 \%$ são constituídos de células do tipo T (JANEWAY et al., 2001); é possível levantar a hipótese de que a diminuição no peso relativo do timo aqui verificada esteja relacionada à saída precoce de linfócitos $T$ para a circulação periférica. Desta maneira, os mecanismos de homeostase orgânicos procurariam balancear a diminuição de linfócitos circulantes produzido pela planta.

Objetivando-se obter maior confiabilidade dos dados e procurando-se associar os efeitos aos princípios ativos tóxicos presentes na $B$. coridifolia realizaram-se, paralelamente ao estudo biológico, a detecção dos princípios ativos da planta, utilizando-se, para tal, a metodologia de cromatografia em camada delgada (TLC) e 
aquela de alta resolução (HPTLC), tanto dos EEs como dos resíduos obtidos destes. Dessa maneira, os dados provenientes desta avaliação química revelaram, de fato, a presença dos tricotecenos nos extratos da planta. Este achado permite fortemente sugerir que os efeitos sobre as células linfóides de camundongos sejam realmente devidos à ação destas substâncias.

Nos ensaios químicos dos EBs e EEs, observou-se que os tricotecenos macrocíclicos, por serem substâncias terpenóides e, consequentemente, apresentarem características físico-químicas mais apolares, deveriam estar em maiores concentrações nos resíduos obtidos dos EEs, mais especificamente no resíduo hexânico, que deveria conter a maior quantidade destas substâncias. Assim, baseandose nos resultados da análise química dos EBs e EEs, bem como de seus resíduos, decidiu-se utilizar o EE2 e o seu resíduo hexânico obtido para realização dos experimentos seguintes.

Procurando-se verificar o efeito do extrato EE2 e seu $\mathrm{RH}$ sobre a proliferação das células A20, timócitos e esplenócitos, procedeu-se ao estudo in vitro, o qual mostrou que o tratamento com as doses de $10 \mathrm{mg} / \mathrm{ml}, 1 \mathrm{mg} / \mathrm{ml}, 100 \mu \mathrm{g} / \mathrm{ml}$ e $10 \mu \mathrm{g} / \mathrm{ml}$ do EE2 não promoveu alteração, em nenhuma das células avaliadas. Por outro lado, o tratamento com $\mathrm{RH}$ nas doses de $10 \mathrm{mg} / \mathrm{ml}$ e $1 \mathrm{mg} / \mathrm{ml}$ reduziu significantemente a proliferação celular do linfoma A20 sem alterar a proliferação dos timócitos e esplenócitos. Este resultado indicou a necessidade de, novamente, realizar este experimento, utilizando-se apenas a menor dose $(1 \mathrm{mg} / \mathrm{ml})$, nas mesmas células anteriormente testadas e também no tumor de Ehrlich, já que é amplamente conhecido que esta última linhagem tumoral apresenta grande potencial proliferativo e de resistência a quimioterápicos (MATSUZAKI, 2006). Os resultados da presente pesquisa mostram, in vitro, claramente que o $\mathrm{RH}$ da B.coridifolia é capaz de diminuir a viabilidade das células tumorais, sem influenciar na viabilidade de timócitos e esplenócitos.

Com o corpo de dados obtidos com o RH até aquele momento, optou-se pela continuidade da avaliação deste resíduo, mas agora retomando o estudo in vivo. Para tal, inicialmente, procurou-se utilizar como sujeito experimental o camundongo Balb/C; no entanto "experimentos pilotos" paralelos, inoculando-se o tumor nestes animais, não lograram êxito, visto que este apresentava involução espontânea nestes animais. Foram então escolhidos os camundongos da linhagem nude para inoculação do linfoma 
A20. Sabendo-se que esta linhagem de camundongos é imunodeficiente (CORDIER, A. C.; HAUMONT, S.M, 1980) e que, por isso, poderiam apresentar respostas completamente díspares daquelas verificadas com os camundongos das linhagens Swiss e Balb/C, além de haver outra variável - o gênero, pois estes camundongos nude eram fêmeas -, optou-se por realizar experimentos prévios, tanto para a obtenção da dose tóxica do $\mathrm{RH}$ para estas fêmeas, quanto para a avaliação de parâmetros hematológicos dos animais sadios. Com efeito, a observação de que a dose tóxica para estes animais foi de $1 \mathrm{~g} / \mathrm{kg}$ corrobora a hipótese de que estes animais seriam mais sensíveis ao efeito da planta. Portanto, no experimento in vivo com esta mesma linhagem de camundongos, decidiu-se por utilizar uma dose $50 \%$ menor de $\mathrm{RH}$ do que aquela tóxica aguda obtida de outras linhagens.

Os resultados deste experimento mostraram que os animais que foram submetidos aos diferentes tratamentos, tanto com ciclofosfamida, bem como naqueles que receberam a associação do resíduo hexânico e ciclofosfamida ou apenas pelo resíduo hexânico, apresentaram diminuição significante do tumor. Deve-se ressaltar, ainda, que camundongos que não receberam nenhum tratamento precisaram ser submetidos à eutanásia três dias antes do final do período de experimentação, já que apresentavam manifestações clínicas e comportamentais que indicavam presença de dor (apatia, anorexia, andar cambaleante, dispneia).

Quanto à histopatologia aqui realizada, este estudo claramente evidenciou que os animais que não receberam ciclofosfamida ou resíduo hexânico apresentavam metástases no fígado, baço, linfonodos e pulmão, enquanto que, aqueles camundongos que receberam a ciclofosfamida associada ao resíduo hexânico, foram bem menos afetados pela presença de células neoplásicas nestes diferentes órgãos. Além disso, embora não tenha sido quantificada, a metástase do linfoma parece ter afetado de maneira mais intensa o baço dos animais controle. Reforça este achado o fato de que os animais que não foram submetidos a nenhum tratamento possuíam um significante aumento do peso relativo deste órgão, podendo-se teorizar que esta alteração seria devido à massiva presença de linfócitos neoplásicos. De fato, Chaise e colaboradores (2007), estudando alterações em camundongos causadas pelo linfoma A20, verificaram também este mesmo efeito. 
Outros dados interessantes obtidos nesta pesquisa foram aqueles provenientes do estudo bioquímico. Assim, observou-se que os camundongos oriundos do grupo controle apresentaram grande aumento da atividade da enzima ALT hepática, seguido de aumento dos níveis da enzima GGT. Considerando-se que a ALT é encontrada em altas concentrações no citoplasma dos hepatócitos, e que o aumento de sua concentração sérica indica extravasamento celular, conclui-se, portanto, que estes animais mostravam lesão hepática (KANEKO, 2008). Além disto, sabe-se que a GGT é uma enzima presente em alta concentração na membrana dos hepatócitos, e embora não seja exclusivamente encontrado no tecido hepático, o seu aumento pode indicar congestão hepática ou obstrução biliar (KANEKO, 2008). Portanto, a análise da avaliação bioquímica permite sugerir que naqueles animais, que não foram submetidos aos diferentes tratamentos, ocorreu maior invasão tumoral, o que acarretaria em danos nos hepatócitos, bem como nas vias biliares e, por conseguinte, destruição de tecido hepático e, conseqüentemente, o aumento de ambas as enzimas.

Embora os animais dos grupos tratados não mostrassem alterações bioquímicas significantes no que se refere aos níveis de ALT e GGT, foi possível detectar que os camundongos provenientes de todos os grupos experimentais apresentaram discreta hipoalbuminemia, quando comparados aos animais sadios. Uma provável explicação para tal achado poderia estar relacionada ao fato de que não houve período hábil para a normalização da produção de albumina pelo fígado. Assim, futuramente, será necessário realizar um experimento no qual os animais serão avaliados também em períodos posteriores ao aqui estudado, para melhor dar suporte a esta conjectura.

A associação destes dados relativos ao estudo bioquímicos aqui obtidos revelou, mais uma vez, que o $\mathrm{RH}$ foi eficaz no tratamento de tumores, impedindo de alguma maneira o crescimento de células tumorais. Além disto, a observação da maior diminuição do diâmetro tumoral naqueles camundongos do grupo $\mathrm{RH}-\mathrm{C}$, permite sugerir um possível efeito sinérgico entre $o$ resíduo hexânico de $B$. coridifolia e a ciclofosfamida.

Ainda, em relação aos tratamentos dos camundongos portadores de linfoma, a avaliação hematológica mostrou a ocorrência do aumento no número absoluto de linfócitos circulantes. Comparativamente aos camundongos nude, que não tiveram implantados o tumor, verificou naqueles animais do grupo controle moderada 
leucocitose por linfocitose, o que poderia sugerir ser devido à presença de linfócitos neoplásicos circulantes. Corrobora tal teoria a presença de cerca de 30\% de linfócitos atípicos observados no esfregaço sanguíneo destes animais. Nos animais tratados com o resíduo da planta e/ou ciclofosfamida, apesar de não haver alterações significantes quanto ao número de leucócitos totais, ocorreu discreta linfopenia quando se comparou com os valores obtidos dos animais não portadores de tumor. A associação destes achados indica que os tratamentos aqui empregados, associados ou não, podem promover a morte tanto de linfócitos normais quanto de linfócitos neoplásicos. No entanto, são necessários outros experimentos posteriores que possam comprovar ou descartar tal hipótese.

Além disto, a hematologia mostrou que o número de plaquetas dos animais do grupo controle apresentou-se diminuído, tanto em relação àquele dos animais dos grupos tratados, como daquele dos animais sadios. Essa significante trombocitopenia pode ser um indício da expressiva evolução tumoral nestes animais do grupo controle. De fato, Chaise e colaboradores, 2007, trabalhando com camundongos portadores deste mesmo tumor, relatam a disseminação do linfoma para fígado, linfonodos e baço, resultando em organomegalia nestes animais. Outro estudo, em cães, conduzido por Couto e colaboradores, 1992, verificou a ocorrência de trombocitopenia nos animais que apresentavam esplenomegalia decorrentes da evolução de neoplasias.

Sabe-se que a redução na quantidade de plaquetas no sangue (trombocitopenia) é um achado comum em portadores de neoplasias (MOULTON; HARVEY, 1990; COUTO, 1992; WITHRO; MACEWEN'S, 2007), sendo que tal alteração seria devida a cinco mecanismos principais: aumento do seqüestro e destruição pelo baço aumentado (hiperesplenismo), redução na produção pela medula óssea, deficiência de ácido fólico, destruição por mecanismos imunológicos e por coagulação intravascular disseminada (COUTO, 1992; WITHROW; MACEWEN'S, 2007).

Portanto, sabendo-se que a trombocitopenia possa ocorrer por diferentes mecanismos, e que nos camundongos, de todos os grupos, que receberam os diferentes tratamentos, não foram evidenciadas alterações na celularidade da medula óssea, pode-se supor que qualquer alteração no número de plaquetas circulante aqui encontrada não estaria relacionada à modificação na produção destas pela medula óssea e sim que esta trombocitopenia verificada nos animais do grupo controle se deva 
à esplenomegalia, alterações hepáticas e circulatórias. Já a trombocitose encontrada nos animais dos grupos $\mathrm{RH}$ e ciclofosfamida poderia estar relacionada a um mecanismo reflexo, em resposta ao consumo das plaquetas por seqüestro esplênico, pelo avanço da neoplasia (com possível hiperesplenismo e hipertensão portal). Assumindo-se esta conjectura, a presença de hematopoiese extramedular, evidenciada pelo aumento de megacariócitos no baço destes animais, revelada no exame histopatológico do órgão, poderia ser resultado da tentativa do organismo em responder ao consumo destas células pela evolução tumoral. No entanto, considerando-se tal suposição, deveria ser esperado um quadro semelhante naqueles animais pertencentes aos grupos controle e $\mathrm{RH}-\mathrm{C}$, o que não foi evidenciado. Porém, deve-se ponderar que, em relação aos camundongos não tratados, a rápida evolução tumoral provavelmente não tenha permitido a recuperação e resposta do organismo, enquanto que os animais submetidos ao tratamento com $\mathrm{RH}-\mathrm{C}$ teriam possivelmente se recuperado do linfoma. De fato, estes camundongos foram aqueles que mostraram maior involução tumoral. Assim, o equilíbrio orgânico entre produção de plaquetas pela medula óssea e o consumo destas por uma possível destruição e seqüestro destas células pela congestão esplênica levaria os animais deste grupo a apresentarem níveis plaquetários mais próximos aos daqueles verificados em animais sadios.

Finalmente, o exame de sangue neste estudo revelou, por meio da avaliação da porcentagem de eritrócitos (hematócrito ou ht), que todos os camundongos dos diferentes grupos experimentais apresentavam-se discretamente anêmicos, quando comparados aos animais sadios. A anemia é uma desordem que frequentemente acomete os portadores de câncer. Em pacientes humanos, cerca de $50 \%$ dos portadores de linfoma apresentam anemia (BENETT; SCHECHTER, 2010). A anemia, como resultado da presença de um câncer, parece estar relacionada com vários fatores, incluindo inflamação crônica, hemólise, neovascularização tumoral, baixos níveis séricos de eritropoietina, baixa resposta da medula óssea à eritropetina e infiltração da medula óssea por células neoplásicas (COIFFIER, 2000).

Embora a contagem de reticulócitos para a classificação da anemia não tenha sido realizada nos camundongos dos diferentes grupos, pode-se sugerir que, nesta pesquisa, o decréscimo do hematócrito nos animais com linfoma esteja relacionado à neovascularização tumoral e congestão de órgãos (principalmente no baço). Entretanto, 
como não foram avaliadas a ocorrência de hemólise extravascular e diminuição dos níveis séricos de eritropoietina, estes fatores não podem ser descartados como possíveis causadores da alteração no hematócrito. Ainda, deve-se considerar que possa ter havido uma possível diminuição da resposta da medula óssea à eritropoietina, o que levaria à hipoplasia eritróide ou desiretropoiese, com queda do hematócrito. Assim, embora a contagem do número total de células da medula óssea dos camundongos com linfoma não tenha diferido daquela dos camundongos sadios, uma análise mais específica da classificação e diferenciação das células medulares será necessária para descartar ou não a hipótese de que a série eritróide não foi prejudicada. Ainda, em relação a isto, deve-se considerar que em muitos casos a hipoplasia eritróide pode ser evidenciada mesmo com a celularidade medular normal, pois o aumento de outra linhagem celular, como os neutrófilos, por exemplo, concomitantemente ao decréscimo da série eritróide, pode dar a falsa idéia de que a celularidade da medula óssea apresenta-se dentro dos padrões de normalidade (HARVEY, 2001)

Concluindo, este trabalho é aquele que primeiro evidenciou os efeitos antitumorais do resíduo hexânico de $B$. Coridifolia, tanto in vivo quanto in vitro, em células neoplásicas de linfoma-B (A20) e carcinoma murino (Ehrlich). Portanto, é possível, sugerir a priori que os princípios ativos presentes na planta poderiam ser candidatos para potencial tratamento de algumas formas de tumores. No entanto, esta é apenas a primeira etapa desta pesquisa. Deste modo, se por um lado o presente estudo permitiu evidenciar efeitos antitumorais promissores desta planta, questões surgiram e, neste momento, não há dados experimentais que embasariam respostas a elas. De fato, com estes resultados aqui obtidos, podem-se levantar algumas hipóteses, tais como que os mecanismos para a diminuição do tumor seriam devido à capacidade dos princípios ativos de $B$. Coridifolia causarem a morte de linfócitos, sendo que este efeito estaria relacionado à ação direta destes nos linfócitos em replicação, do que um efeito secundário, resultante de ativação do sistema imune. Entretanto, o efeito destes princípios ativos em células NK e macrófagos não podem ser alijados e devem ser futuramente avaliados.

Logo, este trabalho possibilita dar início a vários outros estudos que procurarão não somente comprovar este efeito antitumoral da planta, como também esclarecer se, 
de fato, seriam os tricotecenos aqueles princípios ativos responsáveis por tal efeito e, sobretudo, como seriam os mecanismos de ação para tal. 
Conclusões 


\section{CONCLUSÕES}

$\checkmark$ A presente pesquisa corrobora estudo anterior, reproduzindo também os efeitos tóxicos da B.coridifolia em camundongos;

$\checkmark$ dentre os extratos de $B$. coridifolia, o etanólico (EE) mostrou-se mais tóxico para os camundongos, comparativamente ao extrato bruto (EB). O resíduo hexânico $(\mathrm{RH})$ por sua vez, mostrou-se ainda mais tóxico para os camundongos do que o extrato etanólico;

$\checkmark$ o resíduo hexânico da $B$. coridifolia diminui a viabilidade de células tumorais de linfoma A20 e Ehrlich em tratamento in vitro;

$\checkmark$ os efeitos tóxicos da $B$. coridifolia sobre linfócitos são mais pronunciados naqueles tumorais. Além disto, supõe-se que este efeito também ocorra em outras células tumorais de origem linfóide;

$\checkmark$ a administração do resíduo hexânico da $B$. coridifolia, isoladamente ou em associação com a ciclofosfamida promove melhora clínica em camundongos portadores de linfoma;

$\checkmark$ o resíduo hexânico da $B$. coridifolia, isoladamente ou em associação com a ciclofosfamida diminui a ocorrência de metástase em camundongos portadores de linfoma;

$\checkmark$ os camundongos da linhagem nude podem servir como modelo experimental para o estudo do linfoma;

$\checkmark$ a análise química dos extratos, realizado por meio de cromatografia em camada delgada e cromatografia em coluna, sugere a presença de tricotecenos macrocíclicos nas amostras analisadas. 


\section{REFERÊNCIAS}

BARROS, C. S. L. Intoxicações por plantas que afetam o tubo digestivo. In: RIETCORREA, F.; MÉNDEZ, M. C.; SCHILD, A. L. Intoxicação por plantas e micotoxicoses em animais domésticos. Pelotas: Editorial Hemisfério Sul do Brasil, 1993. v.1, cap. 6, p. 159-169.

BENETT, M.; SCHECHTER G.P.Treatment of splenic marginal zone lymphoma: splenectomy versus rituximab. Seminars in Hematology. v. 47, n.2, p. 143-147, 2010.

CHAISE C., ITTI E; PETEGNIEF Y.; WIRQUIN E.; COPIE-BERGMAN C.; FARCIET J. P. [F-18]-Fluoro-2-deoxy-D-glucose positron emission tomography as a tool for early detection of immunotherapy response in a murine $B$ cell lymphoma model. Cancer Immunol Immunother. v.56, n.8,p. 1163-1171, agosto, 2007.

CHUNG, Y. J.; JARVIS, B. B.; PESTKA, J. J. Modulation of lipopolysaccharide induced proinflamatory cytokine prodution by safratoxins and other macrociclyc trichothecens in the murine macrophage. Journal of Toxicology and Environmental Health. v.66,p.379-391, 2003.

COIFFIER, B. The impact and management of anaemia in haematological malignancies. Medical Oncology. v.17, p.2-10, 2000.

COStA, E. R.; COSTA, J.N.; ARMIEN, A.G.; BARBOSA, J.D.; PEIXOTO, P.V. Intoxicação experimental por Baccharis coridifolia (Compositae) em eqüinos. Pesquisa Veterinária Brasileira. v.15,n.1, p.19-26, 1995.

COUTO, C. G. Moléstias dos linfonodos e baço. In: ETTINGER, S. J. Tratado de medicina interna veterinária. 3. ed. São Paulo: Manole, 1992. cap. 115, p. 2328-2348. 
CORDIER, A. C.; HAUMONT, S.M. Development of thymus, parathyroids, and ultimo-branchial bodies in NMRI and nude mice. The American Journal of anatomy. v.157, n. 3, p.227-263, 1980.

DOBERENER, J.; REZENDE, A.M.L.; TOKARNIA, C.H. Intoxicação experimental por Baccharis coridifolia em coelhos. Pesquisa Agropecuária Brasileira Série Veterinária. v.11, p.27-35, 1976.

FIGHERA A. R.; SOUZA M. T.; BARROS C. S. L. Linfossarcoma em cães. Ciência Rural, Santa Maria. v.32, n.5, p.895-899, 2002.

FROQUET, R.; SIBIRIL, Y.; PARENT-MASSIN, D. Trichothecen toxicity on human megakaryocyte progenitors (CFU-MK). Human Experiment Toxicology. v.20, p. 84-89, 2001.

GARCIA, C. C.; ROSSO, M. L.; BERTONI, M. D.; MAIER, M. S.; DAMONTE, E. B. Evaluation of the antiviral activity against Junin vírus of macrociclyc trichothecenes produced by the hypocrealen epibiotic of Baccharis coridifolia. Planta Med. v.68, p. 209-212, 2002.

GOBBO-NETO, L., LOPES, N. P. Plantas Medicinais: Fatores de influência no conteúdo de metabólitos secundários. Química Nova, v.30. n.2, p. 374-381, 2007.

HABERMEHL, G. G.; BUSAM, L.; HEYDER, P.; MEBS, D.; TOKARNIA, C. H.; DOBEREINER, J.; SPRAUL, M. Macrocyclic trichothecene: cause of livestock poisonings by the Brazilian plant Baccharis coridifolia. Toxicon. v. 23 , n. 5, p. 731 745, 1985.

HARVEY, J.W. Atlas of veterinary hematology - blood and bone marrow of domestic animals. Pensylvanya: Saunders, 2001.228p. 
HUGHES, B. J.; HSIEH, G. C.; JARVIS, B. B.; SHARMA, R. P. Effect of macrociclyc trichothecenes mycotoxin on the murine system. Archives of Enviromental Contamination and Toxicology. 1989; 3: 88-95.

ISAKA, M.; PUNYA, J.; LEITWERAWAT, Y.; TANTICHAROEN, M.; THEBTARANONTH $\mathrm{Y}$. Antimalarial activity of macrociclyc trichothecenes isolated from the fungus Myrothecum verrucaria. Journal of natural products. v.62, p.329-331, 1999.

JARVIS, B. B.; COMEZOGLU, S. N.; RAO, M.; PENA, N. B. Isolation of macrocyclic trichothecenes from a large-scale extract of Baccharis megapotamica. The Journal of Organic Chemistry. v. 52, p. 45-56, 1987.

JARVIS, B. B.; MIDIWO, J.; BEAN, G. a ; ABDOUL-NASR, M. B.; BARROS, C. S.The mysterry of trichothecene antibiotics in Baccharis species. Journal of Natural products. v. 51, n. 4, p. 736-744, 1988.

KANEKO J. J.; HARVEY J. W.; BRUSS M. L. Clinical Biochemistry of domestic animals. 6ed. San Diego: Academic press, 2008.916p.

KIM KJ, KANELLOPOULOS-LANGEVIN C, MERWIN RM, SACHS DH, ASOFSKY R. Establishment and characterization of BALB/c lymphoma lines with B cell properties. Journal of Imunology. v. 122, n.2,p. 549-554, 1979.

KUPCHAN, S. M.; STREELMAN, D. R.; JARVIS, B. B.; DAYLEY, R. G.; SNEDEN, A.T. Isolation of potent new antileukemic trichothecenes from Baccharis megapotamica. The Journal of Organic Chemistry. v. 42, n. 26, p. 4221-4225, 1977.

MATSUZAKI P.; HARAGUCHI M.; AKISUE G.; OLORIS S.C.; NAGAMINE M. K.; SILVA T. C.; SAKAI M.; MONTEIRA F. E.; PALERMO-NETO J.; GÒRNIAK S.L.; DAGLI M. L. Antineoplastic effects of butanolic residue of Pfaffia paniculata. Cancer Lett, v.238, n.1, p. 85-89, 2006. 
MOULTON, J. E.; HARVEY, J. W. Tumor of Iymphoid and hematopietic tissue. In Moulton J. E. (ed): Tumors of domestic animals, $3^{\text {rd }}$ ed. Berkeley, University of California press, 1990. p. 231-307.

NAGATA, T., SUZUKI, H., ISHIGAMI, N., SHINOZUKA, J., UETSUKA, K., NAKAYAMA, $\mathrm{H}$., DOI, K. Development of apoptosis and changes in lymphocyte subsets in thymus, mesenteric lymph nodes and Peyer's patches of mice orally inoculated with T-2 toxin. Experimental Toxicology Pathology. v. 53, p. 309-315, 2001.

OCCHIONI, P. Contribuição ao estudo da "mio-mio", Baccharis coridifolia D. C. Boletim da Sociedade Brasileira de Medicina Veterinária. v. 13, n. 3/4, p. 193-209, 1944.

RAFAI, P.; TUBOLY, S.; BATA, A.; TILLY, P.; VANYI, A.; PAPP, Z.; JAKAB, L.; TURY, $E$. Effect of various levels of T-2 toxin in the immune system of growing oigs. Veterinary. Research. v.136, p. 511-514, 1995.

ROTTER, B.A.; PRELUSKY, D.B.; PESTKA, J.J. Toxicology of deoxynivalenol (vomitoxin). J. Toxicol. Envirom. Health. v.48, p. 1-34, 1996.

JANEWAY, CHARLES A.; TRAVERS, PAUL; WALPORT, MARK; SHLOMCHIK, MARK. Immunobiology: The immune system in health and desease. 5th ed. New York: Garland Publishing, 2001. 732p.

SUDAKIN, D.L. Trichothecenes in the environment:relevance to human health. Toxicology Letters. v.143, n.2, p.97-107, 2003.

SWANSON, S.P.; HELASZEK, C.; BUCK, W.B.; ROOD, H.D.; JR HASCHEK, W.M. The role of intestinal microflora in the metabolism of trichothecene mycotoxins. Food Chemicals Toxicology. v.26, p.823-829, 1988. 
THUVANDER, A.; WIKMAN, C.; GADHASSON, I. In vitro exposure of human lymphocytes to trichothcenes: individual variation in sensitivity and effects of combined exposure on lymphocyte function. Food Chemicals Toxicology. v. 37, p. 639-648, 1999.

TOKARNIA, C.H.; DOBEREINER, J. Intoxicação experimental em bovinos por "miomio", Baccharis coridifolia. Pesquisa Agropecuária Brasielira Série Veterinária. v. 10, p.79-97, 1955.

TOKARNIA, C.H.; DOBEREINER, J. Intoxicação experimental em ovinos por "miomio", Baccharis coridifolia. Pesquisa Agropecuária Brasielira Série Veterinária. v. 10, p.19-26, 1976.

TOKARNIA, A.C.H.; DOBEREINER, J.; PEIXOTO, P. V. Plantas tóxicas do Brasil. Rio de Janeiro: Helianthus, 2000. 310p.

UENO, Y. Developments in food science 4. TRICHOTHECENES - Chemical, Biological and Toxicological Aspects. Elsevier: Amsterdam. 309 p., 1983.

UENO, Y.; UEMORI, K.; NIIMI, E.; TANUMA, S. I.; NAGHTA, S.; SUGAMATA, M.; IHARA, T.; SEKIJIMA, M.; KAWAI, K.; UENO, I.; TASHIRO, F. Induction of apoptosis by T-2 toxin and other natural toxins in HI-60 human promyelotic leukemia cells. Natural Toxins. v.3, p.129-137, 1995.

VARASCHIN, M. S.; BARROS, C. S. L.; JARVIS, B. B. Intoxicação experimental por Baccharis coridifolia (Compositae) em bovinos. Pesquisa veterinária brasileira. $v$. 18, n2, p. 69-75, 1998. 
VARASCHIN, M. S. Caracterização Imunoistoquímica de linfócitos em bovinos e camundongos intoxicados experimentalmente por Baccharis coridifolia (Compositae). 2002.62 p. Tese (Doutorado em Medicina Veterinária, área de patologia veterinária). Curso de pós-graduação em Medicina Veterinária, Universidade Estadual Paulista, Jaboticabal, 2002.

WAGNER, H.; BLADT, S. Plant drug analysis: a thin layer chromatography atlas. 2.ed. Berlin: Springer,1996.

WITHROW, S.J.; MACEWEN'S, E.G. Withrow \& Macewen's small animal clinical oncology. 4rd. St Louis: Elsevier Health Sciences, 2007. 